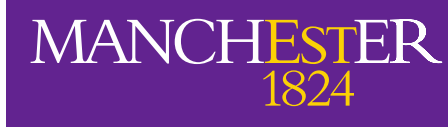

The University of Manchester

Economics

Discussion Paper

Series

EDP-2111

\title{
Do Conditional Cash Transfers Improve Education and Labour Market Outcomes in the Future Generation?
}

\author{
Anqi Zhang, Katsushi S. Imai \\ October 2021 \\ Updated July 2022
}

Economics

School of Social Sciences

The University of Manchester

Manchester M13 9PL 


\title{
Do Conditional Cash Transfers Improve Education and Labour Market Outcomes in the
}

\author{
Future Generation?
}

First Draft: $18^{\text {th }}$ October 2021

This Version: $24^{\text {th }}$ July 2022

\author{
Anqi Zhang $\mathbb{P} \uparrow$ and Katsushi S. Imai $\mathbb{P} €$ \\ P The University of Manchester, The UK, $\uparrow$ Fudan University, China, \\ $€$ RIEB, Kobe University, Japan
}

\begin{abstract}
This paper estimates the long-term impacts of PROGRESA, the Mexican flagship conditional cash transfer programme, on the educational attainment and the labour market performance of children aged 18 years or younger in 1997. Based on the household panel in 1997-2017, we utilise the initial experimental design where the programmes were allocated randomly at the village level in a phased manner. We estimate the intent to treat (ITT) effect by Propensity Score Matching (PSM) with (i) the correction for attrition bias and (ii) controlling for both unobservable and unobservable household characteristics utilising the panel data in 1997-2007. We also estimate the Unconditional Quantile Regressions (UQR) with the same corrections to examine the heterogeneous treatment effects. PSM results suggest that after 20 years, children of the poor eligible households in the early treated villages outperformed the matched children in the control villages. Early beneficiaries achieved better educational attainments in both durations and levels and were more likely to work and earn a higher salary in the regular and non-regular labour markets. We also find spillover effects on children of non-poor households in the treated villages for education and voluntary/non-salaried work. Disaggregation by age groups and gender shows that early-age nutritional support has a long-term positive effect on education and employment for females, while early educational support benefited males rather than females in terms of tertiary education, employment and wages in the regular market. However, UQR results show that the early exposure to PROGRESA increased overall education inequality, while it decreased inequality in education among women and in labour income for both men and women.
\end{abstract}

\section{JEL Classification: I26 I28 I38 J24}

Keywords: Labour market, CCT, Impact evaluation, Mexico

Corresponding Author: Katsushi S. Imai (Dr), Department of Economics, School of Social Sciences, The University of Manchester, Arthur Lewis Building, Oxford Road, Manchester M13 9PL, UK, Email: Katsushi.Imai@manchester.ac.uk.

Acknowledgements: Authors gratefully acknowledge valuable comments on the earlier version of the draft from Ana Vaz, Ralitza Dimova, Indranil Dutta, Jasmin Fliegner, Raghav Gaiha and participants in the NWSSDTP Conference (September 2020) and seminars at the Department of Economics and GDI in Manchester, the UK. Responsibility for any errors in the resulting work remains the authors'. 


\section{Do Conditional Cash Transfers Improve Education and Labour Market Outcomes in the}

\section{Future Generation?}

\section{Introduction}

The primary objective of the present study is to evaluate the long-term effect of PROGRESA, the world's first large-scale conditional cash transfer (CCT) programme in Mexico on education and labour market outcomes. PROGRESA, the Spanish abbreviation for the Programme of Education, Health, and Nutrition (Programa de Educación, Salud y Alimentación), was introduced by the federal government of Mexico in 1997. Targeting the populations in extreme poverty, PROGRESA was designed to achieve its core objective of alleviating poverty through monetary and in-kind benefits in education, health and nutrition. It is the CCT programme as the payment is conditioned by minimum children's school enrolment, attendance, and regular households' clinic attendance.

After 20 years from the first implementation of PROGRESA, the children in the beneficiary households have grown up, and most of them have entered the labour market. To better understand the relationship between access to the programme and the human capital accumulation of children, the main research question we ask in this study is: What is the longterm effect of PROGRESA on educational attainments and labour market performance in Mexico? We will also ask whether the long-term effect differs by age group and gender of children. This is useful to disaggregate the effect roughly into the component of school attendance subsidies and nutritional supplementations for pre-school-aged children. We also examine whether PROGRESA had a spillover effect in the long run on the children of nonpoor households ineligible for the programme in treated villages in comparison with the matched children in control villages. Furthermore, we examine whether the effect is different according to the level of education and salaries. 
This paper contributes to the previous literature by estimating the long-term impact of PROGRESA in 1997 on educational attainments and labour market performance of the treated individuals 20 years later. We will combine the baseline survey data in 1997 (Encuesta de Características Socioeconómicas de los Hogares or ENCASEH) with the follow-up survey data (Encuesta de Evaluación de los Hogares or ENCEL) and examine the long-term programme impact by using variables on educational attainment and employment in 2017 by utilising the experimental feature or randomised controlled trials (RCTs) in 1997 where the treated localities/villages and the control localities/villages were randomly selected. We focus on children aged 18 years or younger $(0-18)$ of the eligible poor households with young children ${ }^{1}$ in 1997 in the villages/localities where the early treatments were randomly assigned and those households started receiving CCTs in the late spring of 1998. All the poor households with young children in the control villages/localities met the eligibility criteria in 1997. However, due to the quasi-experimental design, they became eligible only after November 1999. Comparisons of the outcome variables in 2017 of children in the treated villages and those in the control villages would identify the effect of the 'early' treatment (as the intention to treat (ITT) effect ${ }^{2}$ ) between the late spring of 1998 and after November 1999 - roughly 18 months. In order to identify the spillover effect, we also compare outcome variables of children in noneligible (i.e., non-poor) households in the treated villages and the comparable children in the control villages.

As the education grants stop when children completed the $9^{\text {th }} \operatorname{grade}^{3}$, children who were relatively older and close to completing secondary school were most affected by the 'early'

\footnotetext{
${ }^{1}$ The eligibility criteria will be discussed later.

${ }^{2}$ As not all the eligible households in the initial randomised control trials (RCTs) in 1997 participated in the programme, the effect is considered the ITT effect.

${ }^{3}$ The threshold was increased to the $12^{\text {th }}$ grade in 2001, but as this affected both control and treatment groups, our main estimation strategy focusing on 1998-2000 will not be influenced by this change.
} 
treatment and unlikely to be directly treated after 2000 when they became too old. Thus, we further separate children into three age groups, i.e. 0-5, 6-12 and 13-18 years in 1997 where the first pre-school age group (0-5) benefited most from the nutritional component of PROGRESA, the second (6-12) from its educational component, and the third from the support for the later stage of education and/or other income support at the household level. ${ }^{4}$ These three groups were further disaggregated by gender of children.

Given the long span between the two surveys, we apply Inverse Probability Weights (IPW) in estimating the probit model in Propensity Score Matching (PSM) and the unconditional quantile regressions (UQR) as we discuss later. PSM results show the overall significant and positive impacts of the PROGRESA on educational attainments and labour market performance. Beneficiaries have longer education years and higher school completion rates. They are also more likely to participate in the labour market and earn higher salaries. For instance, in the sub-sample analysis only for children aged 13-18 based on PSM, the ITT effect on their weekly salary is $8.8 \%$, statistically significant, after 20 years of initial implementation. Given the scarce literature on the long-term impact on PROGRESA or CCTs spanning over 20 years, the paper will make an important contribution to the impact evaluation literature on CCTs. ${ }^{5}$ It also contributes to a large body of the literature on the effects of early education or learning and better nutrition of children on labour market outcomes and earnings when they become adults.

\footnotetext{
${ }^{4}$ It should be noted, however, that the children in 13-18 could benefit indirectly from PROGRESA at the household level if they have siblings between the 2nd grade ( 7 years old) to the 8th grade (13 years old or senior) which PROGRESA targeted (Schultz, 2001). The indirect effects could come from not only the cash transfers for the education support for the siblings in the schooling age above but also those for other components, such as medical and nutrition aspects or nutrition packages for pregnant mothers or clinic benefits.

${ }^{5}$ A few ongoing studies analysing the long-term effects of PROGRESA will be discussed in Section 3.
} 
The organisation of the rest of the paper is as follows. Section 2 briefly describes some institutional background. The empirical literature is reviewed in Section 3. Section 4 provides an overview of the data. Section 5 illustrates the econometric specification and estimation approach. Section 6 presents the main empirical results and Section 7 concludes.

\section{$2 \quad$ An Institutional Background}

Following a macroeconomic crisis in Mexico, PROGRESA served as part of a transition towards reducing poverty and eliminating general food subsidies from 1997. In 1997, the programme was implemented experimentally only in selected rural communities in seven states. In 2002, it incorporated urban families in extreme poverty as potential beneficiaries and was renamed "OPORTUNIDADES" (officially, Programa de Desarrollo Humano Oportunidades). In 2014, the programme broadened its intervention strategy and was renamed as PROSPERA Social Inclusion Programme. ${ }^{6}$ After having served as the nation's major poverty alleviation programme for more than 20 years, PROGRESA was abolished and replaced by the unconditional Benito Juárez Scholarships at the beginning of $2019 .^{7}$ The educational component of PROGRESA was substituted by the scholarships provided unconditionally for any qualified children and adolescents of recipient families nationwide.

The PROGRESA was the Mexican flagship CCT programme in poverty reduction and human capital accumulation. In 1997, the programme was implemented experimentally in 506 rural localities from Guerrero, Hidalgo, Michoacán, Puebla, Querétaro, San Luis de Potosí and Veracruz. 320 localities (the "treatment group") were randomly assigned to start receiving benefits from the late spring of 1998. 186 localities were kept as a control group in 1997 and were converted to the treatment groups progressively. From November 1999 (i.e., after 18

\footnotetext{
${ }^{6} \mathrm{We}$ use PROGRESA to refer to the whole policy in the later text.

${ }^{7}$ Mexican Federal Government: https://www.gob.mx/becasbenitojuarez (accessed on $18 / 07 / 2022)$.
} 
months), all initial 506 communities had access to the PROGRESA benefits (see Figure 1). By utilising this phased introduction of the programme, we propose to compare "the early treated" in 320 localities and "the late treated" in 186 localities for the youth aged 0-18 (as well as for subgroups 0-5, 6-12 and 13-18) by making these two groups comparable by PSM. PROGRESA was rolled out nationwide after 2000. By the end of 2018 before the abolition, the programme had included more than 31 million people in around 6.5 million families (a fourth of the country's total population) in all 31 states. The total annual budget had increased from MN\$1 billion, counting $0.03 \%$ of GDP in 1997 to around MN\$83 billion, or $0.4 \%$ of GDP in $2018 .^{8}$

The selection of PROGRESA beneficiaries follows a three-step process. Firstly, the central government selected the localities according to relative geographic marginality. Next, comprehensive household surveys were conducted to gather welfare data in the chosen localities. Finally, the eligibility for PROGRESA is determined by a proxy means test, considering a set of housing conditions, durable goods and socio-economic conditions etc., computed from the 1997 ENCASEH survey (Skoufias et al., 2001a).

There are two important indicators in determining the exit of PROGRESA. A pre-defined minimum welfare line (LBM, by its Spanish acronym, Línea de Bienestar Mínimo) refers to the monthly food consumption per person while the capability line (CL) is the sum of LBM plus expenses on education and health. Both are adjusted with economic growth and inflation. For the graduation process, households' eligibility was reassessed every three years (changed to a five-yearly rotation in 2010), though in reality, the reassessment did not take place in some cases. If the household income was found to be below the LBM in the reassessment, the household continued to be entitled to the benefit. If it was above the LBM but lower than CL, the benefit was reduced while the post-primary education stipends were not affected. All

\footnotetext{
${ }^{8}$ Mexican Federal Government: http://www.gob.mx/prospera (accessed on 18/07/2022).
} 
benefits terminated if the household moved above the CL, and households graduated from the CCT.

As stated in its name, PROGRESA has three main components, i.e., education, health and nutrition. It is a conditional programme as the payment is linked to children's school enrolment and attendance and households' clinic attendance. The education component of PROGRESA was designed to increase school enrolment by making education grants available to pupils' mothers, who are then required to have their children attend school regularly. Every two months, school teachers and directors need to confirm at least $85 \%$ of beneficiary students' attendance to continue to receive the transfer. For each child less than 18 years old and between the third grade of primary school and the third grade of secondary school, the grant amount increases for higher grades and is adjusted every six months for inflation. Moreover, to encourage girls' participation in education, the grant was slightly higher for households with girls than boys.

The health component provided a basic package of health services free of charge consistent with the primary care level. Beneficiaries must also attend doctor's appointments and health training sessions every month. In nutrition, PROGRESA promoted healthcare through free preventative interventions mainly among pregnant women and children below five years old. Receipt of monetary transfers and nutritional supplements were conditional on mandatory healthcare visits to public clinics (Skoufias and Di Maro, 2008).

\section{$3 \quad$ Literature Review}

As the first and most influential CCT in the world, PROGRESA has been extensively studied in the last two decades. Given a large body of literature, we focus only on the studies which assess the effects of PROGRESA on human capital accumulation in this subsection. After reviewing the evaluation studies on education, we will detail a few studies that assess the 
programme's impact on the labour market, especially for the young generation. This allows us to place our methodology and findings in the context of the literature evaluating PROGRESA.

As one of the three goals of PROGRESA, the positive impact on education has been confirmed by several studies (e.g., Skoufias et al., 2001a, b; Behrman and Hoddinott, 2005; Angelucci et al., 2010). As a result, the inequality in the school re-enrolment probability conditional on a child's background - a measure of opportunities - was reduced significantly (Figueroa and Van de Gaer, 2021). Other studies showed that the programme improved children's health and nutritional status (e.g., Rivera et al., 2004; Behrman and Hoddinott, 2005; Barber and Gertler, 2008). Concerning the labour market effect, PROGRESA has successfully reduced child labour (Binder and Scrogin, 1999; Skoufias et al., 2001a). Furthermore, some studies estimated the household-level effect and have confirmed that PROGRESA has reduced household poverty (Skoufias et al., 2001b; McKee and Todd, 2011). However, empirical results on the middle-term effect (e.g., over 10 years) are inconclusive depending on different evaluation methods and data. Bosch et al. (2012) find no effect of the programme expansions on labour market participation or wages using municipal-level data. The authors show that the expansion of CCT shifts informal wage employment to self-employment, but the effect was not persistent from 2000 to 2010. Behrman et al. (2011) found a positive effect of PROGRESA after 10 years on schooling and on work of older girls as well as a shift from agricultural to non-agricultural employment.

Besides PROGRESA, there are several CCTs implemented in other countries, especially in Latin America. Molina Millán et al. (2019) review the literature on the medium/long-term impacts of CCT programmes in Mexico and several developing countries, such as Nicaragua and Colombia. Examining both experimental and non-experimental studies, the authors conclude that children's exposures to CCTs during school age positively affected overall schooling. However, their effect on employment and earnings is inconclusive because the data 
span was too short and beneficiaries did not become too old at the time of the end surveys in most cases. Ham and Michelson (2018) constructed the two-ave, census-based municipal-level panel data for 2001-13 in Honduras and applied the difference-in-difference method to examine the middle-term effect of CCT in 2000-5. They found no lasting impact of demand-side incentives alone, but the provision of both types of support in 2002 resulted in better educational outcomes and higher labour market participation, with a caveat that those treated were not old enough in the end survey and the identifications are based on cross-municipality variations. Later, Molina Millán et al. (2020) combined the same two-wave municipality panel as above with the data in 1988 and applied the single-difference ITT model and concluded that CCT in Honduras resulted in better schooling outcomes and higher international migration rates in 2013.

In Mexico, there is a recent study by Parker and Vogl (2021) based on the 2010 census data to measure the middle-term effect of childhood exposure to PROGRESA on economic outcome variables in early adulthood. They apply the Difference-In-Difference method by utilising 'spatiotemporal variation in programme rollout at the municipality level and cohort variation in the age at which children of eligible households were offered the program' (ibid., 2021, pages 10-11). Here the authors focused on 1999 and 2005 to identify the change in intensities of the programme. Their results indicate that earlier exposure to CCT (before 12 years old) leads to better performance in education completions, earnings, and household economic status when they turn to adulthood and that labour market impacts are more pronounced for women. Kugler and Rojas (2018) also evaluate the middle/long-term impacts of the Mexican CCT on youth employment. The authors combined ENCASEH 1997, ENCEL 2003 and 2007 and 'the Reevaluation, Recertification or VPCS Surveys' in 2008-2015 which included only households that continued as beneficiaries of the programme. Given the high attrition rates (e.g. $12.1 \%$ in $2003,24.6 \%$ in $2007,81.6 \%$ in $2008,99.4 \%-99.9 \%$ in $2010-15$ in Table 2, ibid., 2018), the 
authors pooled the data by combining various rounds and controlled for attritions by applying the inverse probability weights. ${ }^{9}$ They estimated the effect of initial allocation in PROGRESA treatment localities in 1997 and the length of exposure on the outcome. They found that longer exposure to CCTs leads to better educational attainment as well as a higher likelihood and better quality of employment.

Another recent study by Araujo and Macours (2021) is based on a unique survey in 2017 that tracked original households in ENCASEH 1997 for selected age groups of children, the children who were born from 1997 to 1999 (the early children cohort) and those who were in the $6^{\text {th }}$ grade in 1998 (the school cohort). The authors argued that the former group was in the stage where nutrition plays a critical role during the first 1000 days, while the latter was likely to be more influenced by PROGRESA than other age groups. The study was successful in tracking $93 \%$ of the individuals in the two cohorts, including those who migrated to the USA, through the combination of the field visits $(50 \%)$, the phone survey $(35 \%)$ and the survey of remaining members (8\%). Araujo and Macours found a positive effect of PROGRESA on education for the early children cohort and on labour incomes for the school cohort. The study, though commendable, is limited as it may provide an upper bound of the estimate by focusing only on the age groups which were more likely to be affected by PROGRESA than other age groups. Also, the positive income on the labour income of the school cohort comes mainly from the emigrants to the USA, but a positive effect could overstate an actual welfare effect if most of the labour income was spent in the USA or the share of remittance is not taken into account. It is not clear either whether the attrition can be ignored even if the attrition rate due

\footnotetext{
${ }^{9}$ Given the structure of the data, Kugler and Rojas (2018) captured primarily the middle-term effect (5-8 years), rather than the long-term effect (17 years). In their dataset that pooled various surveys in different years, outcome variables, particularly the labour outcomes, are not comparable. Also, both the main explanatory variable, the length of exposure to the programme, and the main dependent variable, education years, are right-censored for subsamples in earlier surveys (in 2003 or 2007) that had the largest share in their dataset. We attempt to overcome these issues using ENCEL 2017.
} 
to death or no-responses is low. Using the ENCEL 2017 data, our study aims to complement their study by (i) focusing on all the age groups influenced by PROGRESA that started in 1998, (ii) analysing the spill-over effects and (iii) estimating the causal effects different at different distributional points of education years and labour income using the UQR model to infer the long-term effect on inequality.

Our study contributes to the recent literature by using the most recent round of households survey data (ENCEL 2017) and matching them to earlier waves of the data (ENCASEH 1997 and ENCEL 2007) to identify how the earlier exposure to PROGRESA for the youth would influence the education and labour outcomes in 2017. ENCEL 2017 enables us to construct the long individual-level panel data and estimate the long-term effects more rigorously for a longer duration than previous works did.

The studies on the long-term impacts of PROGRESA are important in the large body of empirical literature on the interactions among education, health or nutrition and the labour market outcomes and well-being. To address the importance of public policies to support the education of disadvantaged children, Heckman (2006, p. 1900) summarises the importance of social policies to support education in terms of (i) a positive influence on the architecture of the brain and the process of forming skills necessary for a later stage of life, (ii) development of interdependent 'cognitive, linguistic, social, and emotional competencies formation' and (iii) the effective development of specific neural circuits and behaviours they mediate. On the other hand, there is a large body of theoretical and empirical literature showing that better nutrition at early ages (at both pre-school and school ages) will lead to better education or labour market outcomes in later life (e.g., Glewwe et al., 2001; Nandi et al., 2018). In this context, Conti et al. (2010) examined the interaction between education and health and found that family background characteristics as well as cognitive, non-cognitive, and health endowments developed by age ten determinants of the labour market and health outcomes and disparity at 
age 30. We expect PROGRESA to have a positive long-term effect on the labour market outcome not only through the skill formations but also through improvement in health and nutritional status, which would further enhance schooling and labour market outcomes over time.

\section{$4 \quad$ Data and Descriptive Statistics}

Before the official implementation of PROGRESA, a baseline survey (ENCASEH 1997) was conducted in October 1997 to assign the treatment to extremely poor households randomly. Later, the first six ENCELs surveys followed up the interviewees every six months until 2000 and collected the data in 506 rural localities covering 320 treatment and 186 control from seven states of Mexico: Guerrero, Hidalgo, Michoacán, Puebla, Querétaro, San Luis de Potosí y Veracruz. In 2000, all the original sample households, irrespective of whether treated or not in 1997, were incorporated into the treatment group of PROGRESA.

Our econometric analysis is based on the three-wave panel data for 1997, 2007 and 2017, focusing on the treated and control households in 1997. Here (i) ENCASEH 1997 is set as a baseline and ENCEL 2017 is used to compare outcome variables for the treatment and control groups and (ii) ENCASEH 1997 and ENCEL 2007 are used to control for the unobservable household fixed effect. For the latter, we construct the Multidimensional Poverty Index (MPI) at the household level using the panel data and predict the household fixed effects by the panel model. Then we control for the predicted unobservable household fixed effects in the final model to compare outcome variables of treatment and control groups in $2017 .{ }^{10} \mathrm{We}$ present this data collection process along with the policy evolution in Figure 1.

\footnotetext{
${ }^{10}$ We have also applied the same models to the panel data constructed by the two rounds of 1997 and 2007 to identify the mid-term effect of the early exposure to PROGRESA. We have found a statistically significant result of the early exposure to PROGRESA only on the probability of completing high school. The magnitude is much smaller than observed in the
} 


\section{[Figure 1 to be inserted around here]}

The original 506 communities in the baseline survey had 24,077 households and about 125,674 individuals, including adults and children (Parker and Todd, 2017). As described above, PROGRESA improved the youth's human capital by providing nutrition packages and granting scholarships until they complete secondary school. According to the education system in Mexico, pupils are supposed to accomplish secondary school at the age of 15, although a nonnegligible share of the pupils repeats the same grades. Considering some delays in practice, we focus on the individuals aged 18 years or younger in 1997 who were likely to benefit from PROGRESA from 1998. Consequently, the sample size in 1997 has reduced to 42,847 (34.1\% of the total individuals as we focus only on children) from 13,031 households in our 1997 baseline sample, among which 20,012 individuals from 5,618 households were followed up in 2017 (Table 1). The full age breakdown in 1997 is shown in Online Appendix Figure 1.

\subsection{Attrition}

One concern in evaluating long-term impacts is that of sample attritions in the panel data. Although the PROGRESA was randomly assigned at the beginning of 1997, the randomness may not be maintained in the panel data. Given the long period between the two surveys, not all households or individuals surveyed in 1997 are present in the 2017 follow-up. Table 1 reports sample sizes in different treatment and attrition statuses for the aggregate sample, males and females, respectively.

case of the 1997-2017 panel. We do not find any positive and significant mid-term effect of PROGRESA on the education years or the labour market outcomes. 


\section{[Table 1 to be inserted around here]}

According to the treatment assignment in 1997 and attrition in 2017, all samples can be divided into four groups: (1) those who were assigned to the treatment group in 1997 and remained in the survey in 2017; (2) those who received treatment in 1997 but have dropped out from the sample by 2017; (3) those who were in the control group in 1997 and remained in 2017; (4) those who were assigned to control group in 1997 but have dropped out by 2017. As shown in Table 1, among our sample of individuals no older than 18 years old in 1997, the attrition rate was around $53 \%$ in both treatment and control groups, for the aggregate sample as well as its subsamples for males and females. The method for correcting for the attrition bias will be discussed in the next section.

\subsection{Variables}

In our estimation, the treatment status is defined at household levels using the data in 1997 , while outcome variables are constructed at individual levels in 2017. We identify the impact by including a dummy variable indicating whether a household was eligible for the programme. As all the households satisfying the eligibility conditions in the control group became eligible and able to access the programme after 2000 , this dummy variable indicates whether the individual belonged to the early treated households or the late treated households.

If a household was assigned to the treatment group in 1997, all children in this household are identified as "early-treated", while those in the control group are considered "late-treated". The late-treated individuals would have been eligible for the early treatment if they had been assigned to the treatment group in 1997 . We match individuals with similar characteristics in both groups and compare their educational attainment and labour market performances in 2017 . After controlling for the attrition bias, the difference can be interpreted as the long-term effect 
of earlier exposure to CCT benefits in 1998-2000, as the comparable individuals in the control group were not assigned the early transfer.

As discussed earlier, after comparing the individuals aged 18 years or younger in the treatment and control groups, we have repeated the same estimations for those aged between 13 and 18 years old, who were most affected by the random assignment of initial PROGRESA benefits. The estimations for those 6-12 and for 0-5 are also carried out for comparison. These cases were further disaggregated by gender.

The children aged 18 years or younger in "treated" households in 1997 (the first case) cover school-aged children entitled to educational grants as well as pre-school children. The "matched" individuals in the control group could not access these benefits in 1998-2000. The "treated" children aged between 13 and 18 in 1997 (the second case) were either directly beneficiaries of the education component of PROGRESA (if they were at or below the $9^{\text {th }}$ grade in 1997) or enjoyed indirect effects through the support for their siblings. The "matched" children in the control group could not enjoy these benefits in 1998-2000. Both treatment and control groups were unlikely to be direct beneficiaries of the programme from 2000 onwards as they were aged 16-20 in 2000 and thus this is the case where the programme effect is supposed to be identified most clearly. The children aged 6-12 years in treated households (the third case) were most likely to be direct beneficiaries of PROGRESA in 1998-2000. ${ }^{11}$ As they reached 9-15 in 2000, children in both treatment and control groups could benefit from the project directly or indirectly from 2000. So the only difference between the treatment and control groups is that the former benefited from an educational grant at either primary or secondary levels as well as the health/nutritional grant - if the household was eligible - in 19982000. In the last case of children aged 0-5 years in 1997, the "treated" children benefited from

\footnotetext{
${ }^{11}$ Here 'age' is used only for broad proxies for completed grades because the programme benefit was based on the actual number of completed grades at the time of enrolment.
} 
the health/nutritional grant in 1998-2000, while those in the control group did not. After 2000, both groups could benefit from the programme directly through the grants for the individuals concerned or indirectly through those for their siblings. To control for the probability of the household receiving indirect benefits, we include the variable, "proportion of young members aged 18 years or younger' as a control variable.

To evaluate the impact of PROGRESA on human capital, we focus on educational attainments and labour market performance. In the questionnaire, interviewees are asked about their final grade and level of education. Accordingly, we generate four binary variables on educational levels (i.e., whether an individual completed primary school, whether completed secondary school, whether completed high school, and whether completed tertiary education or above) and another non-binary variable, schooling years, to capture the duration of education.

Concerning the labour market outcomes, we use whether an individual worked in the labour market (to capture the probability of working) or the weekly or monthly salary received (in the logarithm). The weekly salary reflects the labour income of the informal market where people tend to be paid weekly, while the monthly salary captures the income in the more regulated market. Notably, working status is hard to define, especially in rural areas. Agricultural or domestic work may not generate a wage or salary but is still considered part of labour participation. PROGRESA may have different impacts on the labour market depending on the job type (e.g., paid or unpaid; salaried or non-salaried). Therefore, we further define 'salaried work' and 'non-salaried work' in terms of 'whether an individual worked for earning salaries' or 'whether worked not for earning salaries' in addition to the above binary variable on working status. The salaried workers include those working in both public and private sectors, while non-salaried workers include non-paid family helpers and self-employed. Following the earlier literature (Parker and Skoufias, 2000; Skoufias and Di Maro, 2008), individuals are recognised as 'working' if they report that they worked over the previous week. Furthermore, salaried or 
non-salaried work is identified based on their main occupation reported. Salaried workers include those who were day agricultural workers or non-agricultural employees. All other workers are classified as "non-salaried", including self-employed workers, business owners, domestic workers, unpaid workers, and common land shareholders. ${ }^{12}$

Table 2 presents definitions and summary statistics of the main variables adopted in this study. It includes pre-interventional variables reported in the 1997 baseline survey and the outcome variables in the 2017 follow-up survey. Our selection of covariates is guided by previous studies that evaluated the impacts of PROGRESA on poverty or other outcome variables. These consist of the variables on both households and individual characteristics, including household size, the proportion of household members below 18 years, poverty rate, and the location and attributes of the household head (i.e., sex, age). Columns (1) through (3) show the summary statistics of the control (late-treated) group, while Columns (4) through (6) indicate those of the treatment (early-treated) group, respectively. The last two columns (7) and (8) record the absolute group difference and t-test results to describe the pre-interventional difference between groups. As reported in Table 2, reflecting the initial random assignment of PROGRESA, control and treatment groups are largely balanced as the means of each variable are very close, although t statistics are mostly significant because of the large sample size. After PSM, variables used for PSM are found to be balanced without any statistically significant differences.

\section{[Table 2 to be inserted around here]}

\footnotetext{
${ }^{12}$ There is a considerable degree of heterogeneity in the non-salaried category, but we have bundled it to keep the number of observations reasonably large.
} 


\section{$5 \quad$ Methodology}

\subsection{Attrition Correction}

It should be noted that in ENCEL 2017 only 334 out of the 506 localities were revisited due to budgetary restrictions. While children in 1997 in all the original households were searched and tracked in 334 localities, if they no longer lived in the same households, they were tracked in the same locality, in neighbouring localities, and in one of the three major Mexican metropolitan areas (Mexico City, Guadalajara and Monterrey). Despite the survey team's effort to track the households, given the long period of the two surveys, some individuals were not tracked, if, for instance, the entire household migrated to the places not mentioned above and could not be traced. Following the empirical literature on attrition in large longitudinal samples (Alderman et al., 1999; Mina and Imai, 2017), we follow the identification strategy developed by Fitzgerald et al. (1998) and use Inverse Probability Weights (IPW) to correct it. The IPW gives higher weights for remaining units with a fairly low probability of remaining in the sample to reduce estimation bias (Wooldridge, 2002). This method will correct for the attrition bias at the household level as well as the locality level by having the location variables and the variables at the locality levels in 1997 (e.g. poverty rate).

$\mathrm{P}_{\mathrm{i}}($ Attrition $=1 \mid \mathrm{X})=\varphi\left(\alpha \mathrm{X}_{\mathrm{i}}\right)$

where $X_{i}$ is a vector of household, individual and locality characteristics that may be correlated with attrition. Here we consider both individual and household profiles, i.e., sex, age, the squared term of age, household size and its squared term, location, demographical structure and asset ownership as well as the poverty rate at the locality level. To capture the reasons for attrition better and follow the literature, we insert the interaction term of the treatment assignment and selected covariates (age or the number of siblings disaggregated by age groups). 
It can be assumed, as in Behrman et al. (2011), that attrition occurs randomly conditional on $X_{i \cdot}{ }^{13}$

The regression results are reported in Table 2 for the aggregate sample as well as subsamples for males and females. ${ }^{14}$ Columns (1), (3) and (5) show that the attrition is not random in 2017 and is correlated with age, location, and the demographic and financial situation of households. Relatively older individuals are more likely to migrate or earn a higher income and they are more likely to drop out of the sample. Concerning the household-level factors, the larger the household size is and the less asset it owns, the more likely the household is to drop out. These variables are statistically significant predictors of attrition. Excluding these predictors, we estimate the restricted attrition model in Columns (2), (4) and (6) of Table 2.

\section{[Table 3 to be inserted around here]}

Table 3 shows that relatively older individuals - regardless of gender - are more likely to be attrited, while whether they were treated in 1998 is unrelated to attrition in both unrestricted and restricted probit models. So, broadly speaking, the attrition took place independently of the household access to PROGRESA. In the unrestricted probit, we have interacted the treatment status with age and the number of siblings in different age groups, but none of them is found

${ }^{13}$ Given the long period from 1997 to 2017 , it would be difficult to predict perfectly the attrition using the data in 1997. However, it can be conjectured that controlling for detailed household characteristics, the interaction of some of them with the treatment status and the locality would help us predict the attrition probability reasonably well, given the large sample size. We have tried PSM, OLS, and UQR models with and without correcting attrition bias and have obtained broadly similar results. The method only corrects for the sample weight, further refinement of the attrition probit - which is not possible with the available data - is unlikely to change our conclusion.

${ }^{14}$ The number of observations in Table $2(29,774)$ has been reduced from that in Table 1 $(42,847)$ due to the missing observations in some of the variables. Our procedure for attrition correction takes into account the attrition due to the fact that some of the variables were not observed in the survey data in 1997. Online Appendix Tables 3.1-3.6 show the attrition probit results for sub-sample cases. 
to be statistically significant (Columns (1), (3), and (5)). The results of interaction terms in the restricted probit where statistically significant variables are removed ((2), (4) and (6)) following the common procedure - suggest that, among the treated, the relatively older with fewer siblings in the younger cohort tend to be attritted. The attrition was also correlated with the location, the overall share of children in the household and asset status as found in Columns (1), (3) and (5).

As in Equation (2), IPW is calculated as the inverse of the ratio of the predicted probability from the unrestricted attrition Probit model (Equation (1)) to the predicted probability from the restricted attrition Probit model (where the auxiliary variables are excluded). Throughout this paper, IPWs are used to assign more weight to individuals who remained in the panel.

$I P W=\left(\frac{\text { Predicted Pr. from Unrestricted Equation. } 1}{\text { Predicted Pr. from Restricted Equation } 1}\right)^{-1}$

\subsection{Propensity Score Matching}

While Table 2 shows that treatment and control groups are reasonably well balanced, we apply a quasi-experimental method to minimise the groups' lack of comparability at the individual level (Gertler et al., 2016). Propensity score matching (PSM) constructs a statistical comparison group based on the probability of participating in the treatment, estimated by some predetermined observables (Rosenbaum and Rubin, 1984). Here we control for the unobservable household fixed effects and attrition bias with IPW in estimating a propensity score. To better estimate the unobserved outcome, we compare individuals from the early-treated group and individuals from the late-treated group. The average treatment effect (ATE) - which is considered ITT in our data settings - is derived as the mean difference across comparable

individuals matched by the propensity score. It should be noted that PSM has been applied to 
four cases (i.e., the individuals aged 18 years or younger and the three sub-groups of 13-18, 612 and 0-5 years old) separately for the aggregate sample and male or female subsamples.

In this paper, we follow the instruction of Caliendo and Kopeinig (2008) to conduct PSM. The following Probit model (Equation (3)) is estimated to derive the propensity score.

$$
P_{i}\left(\text { Treatment }=1 \mid X_{i}\right)=\varphi\left(\alpha X_{i}\right)
$$

where $P_{i}$ denotes the probability of individual $i$ belongs to the treatment group, $\varphi$ represents the cumulative normal distribution function of the standard normal distribution, $\alpha$ is the vector of parameters estimated using the Probit model, and $X_{i}$ symbolises the covariates vector of individual $i$. Each individual's probability of being treated is estimated by pre-treatment characteristics on both individual and household levels, i.e. $X$ includes age, gender, location, household size, demographical structure, poverty status and household asset ownership. To address the attrition problem described above, we introduce the IPW in estimating the Probit model.

According to Rosenbaum and Rubin (1983), there are three essential assumptions for the PSM to estimate the ATE: the balancing property of the propensity scores, the conditional independence assumption (CIA) and the common support requirement (CSR). The propensity score's balancing property requires observable covariates' distributions to be the same between treatment and control groups. Caliendo and Kopeinig (2008, p. 35) describe the CIA assumption as "given a set of observable covariates which are not affected by the treatment, potential outcomes are independent of treatment assignment". As we aim to match individuals with similar characteristics but different treatment statuses, some samples may drop out because of no comparable counterparts. Therefore, the region of common support needs to be defined to ensure the propensity score distributions for treatment and comparison group overlap 
(Khandker et al., 2009). CSR is also known as the overlap assumption and requires a matched control observation with similar covariates. To check the balance of the early- and late-treated groups matched by propensity scores, we conduct balancing tests.

If the balancing property is satisfied, we can move to the next step to match the participants to non-participants. There are several different algorithms to conduct matching based on the propensity score. Dehejia and Wahba (2002) compare different matching algorithms and conclude that most matching algorithms will yield similar results if the overlap of the two groups' score distribution is substantial. To increase the precision of estimators, we mainly apply Kernel matching with replacement. Other results using different algorithms are also presented as a robustness check. It should be noted that, unlike the standard PSM, we have controlled for the unobservable household effect through the procedure as discussed below.

\subsection{Controlling for the Unobservable Household Fixed Effects}

Although we carefully address the attrition bias and further balance the treatment and control variables at the individual levels, the unobservable factors which are specific to each household (e.g., the genetic ability or character common among siblings and unchanged at the household level) could influence the outcome variables. We have thus constructed the Multidimensional Poverty Index (MPI) based on Alkire and Santos's (2014) method where the household nonmonetary poverty is measured by the weighted index covering various sub-indices, covering education, health and the living standard of the household in 1997 and 2007 (Appendix Table 1). ${ }^{15}$ The MPI is regressed on characteristics of the household (e.g., the household size, age of

\footnotetext{
${ }^{15}$ We used the data in 1997 and 2007 to construct MPI because ENCEL 2017 did not survey a comprehensive set of household-level variables whilst ENCEL 2007 data contain most of the household-level variables collected in 1997 to enable us to construct an MPI. The secondround data could be taken from the ENCASEH data in May 1998 because household characteristics in 2007 may have been partially affected by PROGRESA. However, we do not have access to the ENCASEH data in 1998. Given the nature of the panel fixed-effects model based on the relatively stable variables, the estimation will provide any factors not
} 
the household head) by the household fixed effects (FE) model (Appendix Table 2). The predicted household FE is controlled for in all the models to estimate the individual outcomes.

\subsection{Unconditional Quantile Model with PS Weighting and FE}

As an extension, we estimate the unconditional quantile regression (UQR) model (Firpo et al, 2009; Rios-Avila, 2020) for continuous outcome variables (i.e., schooling years and labour income) with PS weighting and the unobservable household FE we have discussed so far. Conditional Quantile Regression (CQR) assumes that the rank of the dependent variable is unchanged in response to the change in the explanatory variable and the estimated coefficients at different percentiles cannot be interpreted as a marginal effect. On the other hand, the UQR allows us to estimate 'the impact of changes in the distribution of the explanatory variables on quantiles of the unconditional (marginal) distribution of an outcome variable' (Firpo et al, 2009, p. 953) and thus it is more suitable in our context. Using the UQR model, we will examine the heterogeneous impacts of PROGRESA at different percentile points in the distribution of the outcome variable, $y_{i t}$, while we will also estimate the OLS model as a benchmark.

\section{Empirical results}

\subsection{PSM}

It is recommended by Caliendo and Kopeinig (2008, p. 38) that important variables that would satisfy the CIA should be included in the probit model while including too many variables should be avoided. Paying particular attention to PROGRESA's selection process into

captured by the household characteristics (e.g., family culture, risk attitudes) which may not change in the short run. As the main estimation uses the cross-sectional data in 2017 where the household dummies cannot be included due to the large sample size, it is conjectured that the advantage of including the unobservable effects outweighs the disadvantages. Excluding the unobservable effects from regressions or PSM will not change the pattern of the final results significantly. 
consideration, we have kept the following covariates: age (integer age and age groups), gender, and household characteristics (i.e. household size, the proportion of teenagers, poverty rates and asset ownerships). The matching approach's validity relies on the CIA and the CSR. Figures 2 a-c show the common support regions for the aggregate sample and subsamples for males and females. Observations outside the region of common support have been dropped as no comparable individuals exist in those observations. The same procedure is repeated for all the subsample cases and only a few observations ( 1 to 19 observations depending on the subsample) are dropped, which reflects an overall good performance of the initial RCT as well as the attrition which occurred nearly independently from the treatment status as discussed earlier. Figures 3a-c plot the distributions of the PS in the treatment groups and the control groups. It can be observed that the treatment and control units have a similar distribution in all three years, indicating that the overlap assumption is satisfactory in these cases. We have repeated the same estimation procedure for all the age/gender subgroups and confirmed that the overlap assumption is satisfied in all the cases.

\section{[Figures 2a-c and 3a-c to be inserted around here]}

Several statistical measures to test for the overall balance are presented in Table 4. After matching, a fairly low pseudo-R-square implies a negligible difference between the early- and late-treated groups for all three cases. Rubin's B is the absolute standardised difference of the means of the PS. It is suggested that Rubin's B-value after matching should be less than 25 . Rubin's R-value, which is the ratio of the treated to non-treated variances of the PS, should be higher than 0.5 but less than 2 in the matched data. These statistics imply that the balancing property is satisfactory for the aggregate sample as well as subsamples for males and females. 


\section{[Table 4 to be inserted around here]}

PSM results are presented in Table 5. Columns (1)-(3) are for individuals aged between 0 and 18 in 1997 for both treatment and control groups. ${ }^{16}$ Similarly, Columns (4)-(6) are for the individuals aged between 13 and 18, Columns (7)-(9) are for those aged 6-12 in and Columns (10)-(12) are for 0-5. The results on the spillover effect for 0-18 are shown in Columns (13)(15). Within each group, the first column presents the aggregate result, while the latter two columns address gender disaggregation. To illustrate the effect of the earlier access to PROGRESA straightforwardly for all the cases, we only present the estimates of the earlytreatment dummy and their standard errors. We only present the results of PSM with Kernel marching. It is noted that the estimates with IPW correction are slightly larger than unweighted estimates in all the cases. So ignoring attrition bias would slightly underestimate the policy effect. However, the results without attrition bias and/or the unobservable effects are broadly similar, implying that the effects of attrition bias or the unobservable effects are actually smaller than applied researchers would often assume, at least, in our data context. ${ }^{17}$

\section{[Table 5 to be inserted around here]}

\subsection{Educational Attainments}

As one of the three components in PROGRESA design, Mexico's federal government put a huge effort into promoting the young generation's educational attainments. Table 5 confirms that the

\footnotetext{
${ }^{16}$ As our UQR regression shows, there is a large degree of heterogeneity across the entire distribution. Also, the literature suggests that PSM is superior to linear regression or OLS as the model does not assume linearity. So we present the PSM results reflecting unobservable characteristics and correcting for the attrition bias as our main results. OLS results with the attrition bias correction and the unobservable effects are reported in Online Appendix Table 2.

${ }^{17}$ These results are not presented as they are voluminous. They will be furnished on request.
} 
Government's efforts were effective in improving educational attainments in the long run. ${ }^{18}$ Table 5 indicates that the early exposure to PROGRESA increased education years by 0.23 years in the long run (Columns (1)). The table also shows that the earlier exposure to PROGRESA significantly increased the probability of completing secondary school the most, but it also improved the completion probability at the levels of primary school, high school and tertiary school. More specifically, the probability of completing primary school, secondary school, high school, and tertiary school increased significantly, by $1.2 \%, 1.8 \%, 0.7 \%$, and $0.3 \%$, respectively (Column (1)). Disaggregation results by age groups show that education years significantly increased for all the age groups (Columns (4), (7), and (10)) with the largest effect found in the age cohort between 13 and 18.

The pattern of the results on school completion is broadly similar between the aggregate sample and the older children aged 13-18 as well as the younger children aged 9-12 in 1997 (Columns (4)-(9)) except that the estimates for higher school completion are not statistically significant in the sub-sample cases. Earlier access to PROGRESA has made individuals aged 13-18 and 6-12 in 1997 more likely to complete tertiary school (by 5\%), but not those aged 05 in 1997 (Columns (10)). However, those aged 0-5 in the treated group had more education years (by $0-18$ years) than those in the control group. This result is consistent with the view that health and nutritional support at the pre-school level positively influence education in later years.

The final three columns of Table 5 show the spillover effect of the earlier exposure to PROGRESA on education outcomes of those ineligible or non-poor but within the village where eligible households benefited from PROGRESA. The results have confirmed a positive

${ }^{18} \mathrm{~A}$ full set of the results with other matching algorithms are provided in Online Appendix Tables 1 for the aggregate case. 
and significant spillover effect on education years (by 0.25 years) and on the probability of completing high school (by 1.8\%) in the long run.

We have estimated the same models for males and females (the latter two columns in each age group). To avoid repetitions, we only summarise key findings. First, the long-term effect on education outcomes due to earlier exposure to PROGRESA is higher for females than males. The magnitude of the long-term effect on education years is 0.25 years for women and 0.20 years for men. Women in the treated group are $2.3 \%$ more likely to complete secondary school, while the corresponding figure is $1.5 \%$ for men. So we can conclude that PROGRESA contributed to narrowing the gender gap in education outcomes after 20 years.

Second, however, there is a variation across different age groups between males and females. For instance, young girls aged 0-5 in 1997 benefited more from the earlier exposure to PROGRESA - mainly through health and nutrition support - than young boys aged 0-5 in 1997 in terms of education years, and completion of secondary and high schools (Columns (11) and (12)). Here education years increased by 0.28 years for girls (statistically significant at the $1 \%$ level) and 0.10 years for boys (non-significant). The secondary school completion rate increased by $2.7 \%$ for girls (while it decreased by $0.8 \%$ but was statistically non-significant for boys). High school completion increased by $2.0 \%$ for girls and $0.2 \%$ (and non-significant) for boys.

Third, the spillover effects of PROGRESA are found to be much stronger for girls than for boys. For instance, the spillover effects of the PROGRESA were (i) 0.29 years of a significant increase in schooling years for girls ( 0.14 years and non-significant for boys) and (ii) a $2.0 \%$ significant increase in high school completion for girls (a 1.3\% and non-significant for boys) based on Columns (14) and (15) of Table 5. The reason for the more substantial spillover effects on education for girls is not clear. One possible explanation may be that the Mexican government emphasised the role of PROGRESA in closing the gender gap in education. The 
spread of information may influence the decision-making process on female education from beneficiary households to non-beneficiary households.

\subsection{Labour Market Performance}

As the beneficiaries of higher investment in education and nutrition, the early-treated youths are expected to outperform those receiving PROGRESA later in the labour market. This is proved by Column (1) of Table 5. Regarding overall participation for the entire sample, it shows that individuals in early-treated groups in 1997 were $1.5 \%$ more likely to work in the labour market in 2017. A positive and significant effect on the probability of working for salaries is found (by 1.0\%), while the effect on working for non-salaried work is also observed $(0.6 \%)$. For the total sample, the individuals belonging to the early-treated households are also found to earn a higher salary, both the monthly salary in the regular market $(5.4 \%)$ and the weekly salary in the less regulated market (4.5\%). As payment is made more frequently for the less-skilled positions, the results provide a plausible explanation for a slightly greater improvement in the upper side of the income distribution over the years.

We have disaggregated the sample into males and females and found a gender difference in the long-term effect of PROGRESA on the labour market outcomes (Columns (2) and (3)). We observe more substantial employment effects on women than men except for monthly salaries. Based on PSM estimates, we find that the monthly salary increased by $8.3 \%$ for men (as opposed to $3.9 \%$ for women, non-significant). However, the weekly salary increased by $6.3 \%$ for women, while it did not increase for men. After 20 years of the programme implementation, women in the treatment group are $1.8 \%$ more likely to work in the labour market than those in the control group, while the corresponding figure for men is $1.3 \%$. The early exposure to PROGRESA made women significantly more likely to work for salaries and non-salaries, but these effects are not found for men. 
We have further disaggregated all the cases into different age groups. First, in the case where we restrict the individuals to those aged between 13 and 18 years old (in which neither control nor treatment groups received direct benefits after 2000), women enjoyed a 9.2\% increase in their weekly salary due to the early treatment, while men's salaries did not increase through the early treatment. However, the probability of working for salaries significantly increased only for men, not for women (Columns (5) and (6)).

In Columns (7) and (10), the effects on the labour market outcomes are presented for the individuals aged 6-12 years and those aged 0-5 years in 1997. The results show that the probability of working in the labour market is $1.6 \%$ higher for the former and $2.1 \%$ higher for the latter than the respective control group due to the early exposure to PROGRESA. While the reason is not clear, for those aged 6-12 in 1997, the probability of working for salaries does not increase, but that for non-salaries significantly increased by 0.9\%. Those aged 0-5 in 1997 are more likely to work for salaries and non-salaries (by $1.8 \%$ and $0.7 \%$ respectively) as a result of the earlier programme access. The signs are positive, but we have not found any significant effects on salaries for these subsamples.

Concerning the results by gender, we have found contrasting results (Columns (8), (9), (11) and (12)). We have found stronger long-term employment effects only for "girls aged 0-5 in 1997" and "boys aged 6-12" in 1997. These results imply that early-age intervention in health and nutrition is more effective for girls than boys, while the grant for early-stage education is more effective for boys than girls in improving the long-term labour market outcomes. For the age group 0-5 in 1997, while we do not find any statistically significant coefficient among the five labour market outcome variables for boys, girls in this age group were $2.8 \%(3.2 \%)$ more likely to work in the labour market (work for salaries). They enjoyed significantly higher monthly and weekly salaries (by $10.5 \%$ and $6.5 \%$ respectively) in 2017 than those in the control group. For the age group 6-12 in 1997, we do not find any significant coefficient estimate 
except 'whether working voluntarily' for girls. However, boys in this age group were $2.4 \%$ more likely to work in the labour market, $1.1 \%$ more likely to work voluntarily, and enjoyed a $10.9 \%$ higher monthly salary than the counterfactuals.

Despite positive spillover effects of the earlier exposure to PROGRESA, particularly at the level of high school education, its spillover effects on the labour market outcomes are much weaker than the direct effects we have discussed so far. Only a positive and significant effect is found on 'whether working for non-salaries/voluntarily' (by $0.6 \%$ ). The treatment group earned a lower weekly salary (by 6.9\%) than the control group. The results suggest a weak long-term spillover effect of PROGRESA. This may be because the spillover effects on education were weak and insufficient to help the untreated children of the ineligible non-poor households in the treated villages outperform the matched children in the control group.

\subsection{Unconditional Quantile Results for Continuous Outcome Variables}

In order to examine the heterogeneous impacts of PROGRESA, we have estimated the UQR model with PS weighting and with the unobserved household FE. The results are presented in Table 6. We mainly highlight the variables which show a statistically significant estimate. Column (1) of Table 6 indicates that education years increased significantly as a result of PROGRESA, but the positive effect is found to be much larger for the better-educated or at the 90th percentile where the effect is 0.2 years. This is larger than 0.1 years at the median and 0.13 years at the $10^{\text {th }}$ percentile. ${ }^{19}$ Considering the gender difference in Columns (2) and (3). For all interviewed boys under 18 years, they are more influenced by the early exposure of PROGRESA than girls in all five percentiles and it is higher in the middle-higher levels. Overall, PROGRESA increased education inequality in terms of schooling years.

\footnotetext{
${ }^{19}$ As we follow the method of UQR based on Rios-Avila (2020) not CQR, the estimates, e.g., at the median, are not comparable with OLS.
} 
The UQR results imply some effect of PROGRESA on educational inequality. For instance, Columns (4)-(9) show that the earlier exposure to the education component of PROGRESA benefited girls more than boys in the age groups ' $6-12$ ' and '13-18', especially for those at the median or lower percentiles. However, the nutrition component of PROGRESA mainly benefited girls in the median and upper educational percentiles (Columns (10)-(12)). Overall, we can conclude that educational inequality was reduced by PROGRESA for girls in school age, while overall education inequality was increased by the programme.

Table 6 also shows the UQR results for monthly salaries. ${ }^{20}$ The results show that statistically significant and positive coefficient estimates are found only at the $10^{\text {th }}$ percentile, not at other percentiles. For instance, Column (1) indicates that monthly salary significantly increased by $29 \%$ at the $10^{\text {th }}$ percentile while it significantly decreased by $6 \%$ in 2017 as a result of the earlier exposure to PROGRESA. This is a strong result that is consistent with the long-run inequality-reducing effect of PROGRESA in terms of the monthly wage income. The inequality-reducing effects are found in both men and women (Columns (1) and (2)). For instance, the early exposure to PROGRESA increased the monthly salary for men by $40 \%$ at the $10^{\text {th }}$ percentile while the estimates are smaller and statistically non-significant at other percentiles. For women, the earlier access to PROGRESA increased the monthly salary by $20 \%$, while it decreased by $6 \%$ at the $75^{\text {th }}$ percentile and by $10 \%$ at the $90^{\text {th }}$ percentile. Columns (4)(12) overall show that this pattern of the results is found for all the age groups. The last three columns show that the decrease in inequality in the labour income is also found for those who were not eligible for PROGRESA in the treatment villages (i.e., spillover effects).

\footnotetext{
${ }^{20}$ For the weekly salaries, estimated coefficients are statistically non-significant except in a few cases (e.g., at the $25^{\text {th }}$ percentile or the median where the coefficients are negative and significant). So it is difficult to draw a conclusion and the results are not shown in Table 6.
} 


\section{Conclusion}

This study analyses the long-term impact of PROGRESA on educational attainments and labour market performance of the individuals by utilising the initial experimental or RCT design at the village levels in 1997 where the programme was introduced in a phased manner. We combine ENCASEH 1997 baseline survey with the following-up ENCEL data in 2007 and 2017 and estimate the intent to treat (ITT) effect of PROGRESA by Propensity Score Matching and unconditional quantile regression (UQR) models. Both models control for the attrition bias by Inverse Probability Weights and the unobservable time-invariant household characteristics. We focus on children aged 18 years or younger in 1997 who would benefit from PROGRESA directly or indirectly. As an extension, we have restricted the individuals to subgroups, aged 13-18, 6-12 and 0-5 years and have further disaggregated each subsample into males and females. We have also estimated the spillover effect of PROGRESA by comparing the children in the non-poor non-eligible households in the treated villages and those in the control villages.

Although some estimation variation exists in different models, we find significant and positive long-term impacts of PROGRESA. Concerning educational attainments, early exposure to PROGRESA improves the length of education, the probabilities of secondary and high school completion, and tertiary education participation. Our findings are consistent with the huge effort the Mexican Federal Government has put through PROGRESA in the human capital investment in disadvantaged children since 1997 and the positive and statistically significant effects are found in the longer term, that is, after 20 years of the launch of the programme. It can be inferred from our results that the improvements in beneficiaries' education and health further promoted their labour market performance. If the individuals received the PROGRESA in their childhood, they are more likely to earn a higher salary in both regulated and unregulated labour markets, but particularly in the former. We also find spillover effects on children of non-poor households for education and voluntary work. 
Disaggregation by different age groups and gender show that early-age health and nutritional support aged 0-5 in 1997 had a long-term positive effect on education and employment for women in 2017, but not for men. This result implies that early-age health and nutrition support for girls is particularly important for enduring better education and labour market outcomes, including employment and higher salaries for them, and would narrow the gender gap in wages in the long run. On the other hand, early educational support benefited more males than females in tertiary education as well as employment and wages in the regular market. While a larger amount of cash grants was given to girls at the secondary school level, more benefits and advantages should be provided for girls to narrow the gap in education and labour market outcomes. UQR results imply that the early exposure to PROGRESA decreased education inequality for girls of school ages in 1997, while it increased overall education inequality. On the other hand, inequality in the labour market income in terms of monthly salary decreased for men and women as a result of the early programme access.

Heckman (2006, p. 1902) argued that '(i)nvesting in disadvantaged young children is a rare public policy initiative that promotes fairness and social justice and at the same time promotes productivity in the economy and in society at large'. Though Heckman's focus is more on investment in children's education at pre-school levels, rather than at the schooling age, he also mentions a relatively high magnitude of the rate of returns to human capital investment in the latter. While the Mexican Federal Government replaced the CCT programme with unconditional scholarships, Benito Juárez, in 2019, the present study has provided strong support for CCTs as one of the best options for less developed nations to achieve a fair society without compromising the productivity at the micro-level.

\section{References}

Alderman, H., Behrman, J. R., Kohler, H. P., Maluccio, J. A., Watkins, S. C., 2001. Attrition in longitudinal household survey data: some tests for three developing-country samples. Demographic Research 5, 79-124. doi.10.4054/DemRes.2001.5.4 
Alkire, S., Santos, M. E., 2014. Measuring acute poverty in the developing world: Robustness and scope of the multidimensional poverty index. World Development 59, 251-274. doi.org/10.1016/j.worlddev.2014.01.026

Angelucci, M., De Giorgi, G., Rangel, M. A., Rasul, I., 2010. Family networks and school enrolment: Evidence from a randomized social experiment. Journal of Public Economics 94(34), 197-221. doi.org/10.1016/j.jpubeco.2009.12.002

Araujo, M. C., Macours, K., 2021. Education, income and mobility: Experimental impacts of childhood exposure to progresa after 20 years. Working Paper N 2021 (halshs-03364972), https://halshs.archives-ouvertes.fr/halshs-03364972/.

Barber, S. L., Gertler, P. J., 2008. The impact of Mexico's conditional cash transfer programme, Oportunidades, on birthweight. Tropical Medicine \& International Health 13(11), 1405-1414. doi.org/10.1111/j.1365-3156.2008.02157.x

Behrman, J. R., Hoddinott, J., 2005. Programme evaluation with unobserved heterogeneity and selective implementation: The Mexican PROGRESA impact on child nutrition. Oxford Bulletin of Economics and Statistics 67(4), 547-569. doi.org/10.1111/j.14680084.2005.00131.x

Behrman, J.R., Parker, S.W., Todd, P.E., 2011. Do conditional cash transfers for schooling generate lasting benefits? A five-year followup of PROGRESA/Oportunidades. Journal of Human Resources, 46(1), 93-122.

Binder, M., Scrogin, D., 1999. Labor force participation and household work of urban schoolchildren in Mexico: Characteristics and consequences. Economic Development and Cultural Change 48(1), 123-154. doi.10.1086/452449

Bosch, M., Stampini, M., Bedoya, G., 2012. Are Conditional Cash Transfers Associated with Lower Labor Supply?: Evidence from Mexico's Oportunidades Over the Period 2000-2010. Technical Note no. TN-497. Inter-American Development Bank, Washington DC.

Caliendo, M., Kopeinig, S., 2008. Some practical guidance for the implementation of propensity score matching. Journal of Economic Surveys 22(1), 31-72. doi.org/10.1111/j.14676419.2007.00527.x

Conti, G., Heckman, J., Urzua, S., 2010. The education-health gradient. American Economic Review, 100(2), 234-38. doi.10.1257/aer.100.2.234

Dehejia, R. H., Wahba, S., 2002. Propensity score-matching methods for nonexperimental causal studies. Review of Economics and Statistics 84(1), 151-161. doi.org/10.1162/003465302317331982

Figueroa, J. L., Van de Gaer, D., 2021. Did Progresa Reduce Inequality of Opportunity for School Reenrollment?. Economic Development and Cultural Change 69(2), 541-567. doi/pdf/10.1086/703234

Firpo, S., N. M. Fortin, and T. Lemieux., 2009. Unconditional quantile regressions. Econometrica 77: 953-973. doi:org/10.3982/ECTA6822. 
Fitzgerald, J., Gottschalk, P., Moffitt, R. A., 1998. An analysis of sample attrition in panel data: The Michigan Panel Study of Income Dynamics. Journal of Human Resources 33 (2), 251-299. doi-org.manchester.idm.oclc.org/10.2307/146433

Gertler, P. J., Martinez, S., Premand, P., Rawlings, L. B., Vermeersch, C. M., 2016. Impact Evaluation in Practice, Second Edition. Washington D.C., World Bank Publications.

Glewwe, P.J., Jacoby, H., King, E. M., 2001. Early childhood nutrition and academic achievement: a longitudinal analysis. Journal of Public Economics 81.3: 345-368. doi.org/10.1016/S0047-2727(00)00118-3

Ham, A., Michelson, H. C., 2018. Does the form of delivering incentives in conditional cash transfers matter over a decade later?. Journal of Development Economics 134, 96-108. doi.org/10.1016/j.jdeveco.2018.05.007

Heckman, J. J., 2006. Skill formation and the economics of investing in disadvantaged children. Science 312(5782), 1900-1902. doi.10.1126/science.1128898

Khandker, S. R., Koolwal, G. B., Samad, H. A., 2009. Handbook on Impact Evaluation: Quantitative Methods and Practices. Washington D.C., World Bank Publications.

Kugler, A. D., Rojas, I., 2018. Do CCTs improve employment and earnings in the very longterm? Evidence from Mexico (No. w24248). National Bureau of Economic Research.

McKee, D., Todd, P. E., 2011. The longer-term effects of human capital enrichment programs on poverty and inequality: Oportunidades in Mexico. Estudios de Economia 38(1), 67.

Mina, C. D., Imai, K. S., 2017. Estimation of vulnerability to poverty using a multilevel longitudinal model: Evidence from the Philippines. The Journal of Development Studies 53(12), 2118-2144. doi.org/10.1080/00220388.2016.1265942

Millán, T, M, Barham, T, Macours, K., Maluccio, J. A., Stampini, M., 2019. Long-Term Impacts of Conditional Cash Transfers: Review of the Evidence. The World Bank Research Observer 34(1), 119-159. doi.org/10.1093/wbro/lky005

Millán, T. M., Macours, K., Maluccio, J. A., Tejerina, L., 2020. Experimental long-term effects of early-childhood and school-age exposure to a conditional cash transfer program. Journal of Development Economics 143, 102385. doi.org/10.1016/j.jdeveco.2019.102385

Nandi, A., Behrman, J. R., Kinra, S., Laxminarayan, R., 2018. Early-life nutrition is associated positively with schooling and labor market outcomes and negatively with marriage rates at age 20-25 years: evidence from the Andhra Pradesh children and parents study (APCAPS) in India. The Journal of Nutrition 148(1), 140-146. doi.org/10.1093/jn/nxx012

Parker, S. W., Skoufias E., 2000. The impact of PROGRESA on work, leisure, and time allocation: final report, https://www.ifpri.org/publication/impact-progresa-work-leisure-andtime-allocation (accessed on 22/11/2021). 
Parker, S. W., Todd, P. E., 2017. Conditional cash transfers: The case of Progresa/Oportunidades. Journal of Economic Literature 55(3), 866-915. doi: 10.1257/jel.20151233.

Parker, S. W, Vogl, T., 2021. Do conditional cash transfers improve economic outcomes in the receipt next generation? Evidence from Mexico, mimeo. Available on http://tomvogl.com/parker_vogl_progresa.pdf (accessed on 22/11/2021).

Rios-Avila, F., 2020. Recentered influence functions (RIFs) in Stata: RIF regression and RIF decomposition. The Stata Journal, 20(1), pp.51-94. doi:10.1177/1536867X20909690 DOI: 10.1177/1536867X20909690

Rivera, J. A., Sotres-Alvarez, D., Habicht, J. P., Shamah, T., Villalpando, S., 2004. Impact of the Mexican program for education, health, and nutrition (Progresa) on rates of growth and anemia in infants and young children: a randomized effectiveness study. JAMA 291(21), 25632570. https://jamanetwork.com/journals/jama/article-abstract/198848 (accessed on 22/11/2021).

Rosenbaum, P. R., Rubin, D. B., 1983. The central role of the propensity score in observational studies for causal effects. Biometrika 70(1), 41-55. doi.org/10.1093/biomet/70.1.41

Rosenbaum, P. R., Rubin, D. B., 1984. Reducing bias in observational studies using subclassification on the propensity score. Journal of the American Statistical Association 79(387), 516-524. doi.10.1080/01621459.1984.10478078

Schultz, T. P., 2001. School Subsidies for the Poor: Evaluating the Mexican Progresa Poverty Program, Center Discussion Paper, No. 834, Yale University, Economic Growth Center, New Haven, CT.

Skoufias, E., Parker, S. W., Behrman, J. R., Pessino, C., 2001a. Conditional cash transfers and their impact on child work and schooling: Evidence from the progresa program in Mexico. Economía 2(1), 45-96. https://www.jstor.org/stable/20065413 (accessed on 22/11/2021).

Skoufias, E., Davis, B., De La Vega, S., 2001b. Targeting the poor in Mexico: an evaluation of the selection of households into PROGRESA. World Development 29(10), 1769-1784. doi.org/10.1016/S0305-750X(01)00060-2

Skoufias, E., Di Maro, V., 2008. Conditional cash transfers, adult work incentives, and poverty. The Journal of Development Studies 44(7), 935-960. doi.org/10.1080/00220380802150730

Wooldridge, J. M., 2002. Inverse probability weighted M-estimators for sample selection, attrition, and stratification. Portuguese Economic Journal 1(2), 117-139. doi.org/10.1007/s10258-002-0008-x 
Table 1: Treatment Assignment in 1997 and Attrition in 2017

\begin{tabular}{|c|c|c|c|c|c|}
\hline \multirow[t]{2}{*}{ Aggregate } & & \multicolumn{2}{|l|}{2017} & \multirow{2}{*}{ Attrition Rate } & \multirow{2}{*}{ Total } \\
\hline & & Not-Attrited & Attrited & & \\
\hline \multirow[b]{2}{*}{1997} & \multirow{3}{*}{$\begin{array}{l}\text { Treatment } \\
\text { Control }\end{array}$} & (1) 12,178 & (2) 13,744 & $53.02 \%$ & 25,922 \\
\hline & & (3) 7,834 & (4) 9,091 & $53.71 \%$ & 16,925 \\
\hline Total & & 20,012 & 22,835 & $53.29 \%$ & 42,847 \\
\hline \multirow[t]{2}{*}{ Male } & & 2017 & & \multirow{2}{*}{ Attrition Rate } & \multirow{2}{*}{ Total } \\
\hline & & Not-Attrited & Attrited & & \\
\hline \multirow{3}{*}{1997} & \multirow{4}{*}{$\begin{array}{l}\text { Treatment } \\
\text { Control }\end{array}$} & (1) 5,923 & (2) 6,660 & $52.93 \%$ & 12,583 \\
\hline & & (3) 3,872 & (4) 4,489 & $53.69 \%$ & 8,361 \\
\hline & & & & & \\
\hline Total & & 9,195 & 11,149 & $53.23 \%$ & 20,944 \\
\hline \multirow[t]{2}{*}{ Female } & & 2017 & & \multirow{2}{*}{ Attrition Rate } & \multirow{2}{*}{ Total } \\
\hline & & Not-Attrited & Attrited & & \\
\hline \multirow{3}{*}{1997} & \multirow{4}{*}{$\begin{array}{l}\text { Treatment } \\
\text { Control }\end{array}$} & (1) 6,255 & (2) 7,084 & $53.11 \%$ & 13,339 \\
\hline & & (3) 3,962 & (4) 4,602 & $53.74 \%$ & 8,564 \\
\hline & & 10217 & 11686 & $5335 \%$ & 21003 \\
\hline Total & & 10,217 & 11,080 & $53.55 \%$ & 21,903 \\
\hline
\end{tabular}

Source: Authors' elaboration based on ENCASEH and ENCELs data. 
Table 2: Variable Definition and Summary Statistics

\begin{tabular}{|c|c|c|c|c|c|c|c|c|c|}
\hline \multirow[b]{2}{*}{ Variable } & \multirow[b]{2}{*}{ Definition } & \multicolumn{3}{|c|}{ Late-treated Group } & \multicolumn{2}{|c|}{ "Early-treated group } & \multicolumn{3}{|c|}{$\begin{array}{l}\text { Difference } \\
\end{array}$} \\
\hline & & $\begin{array}{l}\text { Obs } \\
(1)\end{array}$ & $\begin{array}{l}\text { Mean } \\
(2)\end{array}$ & $\begin{array}{l}\text { S.D. } \\
(3)\end{array}$ & $\begin{array}{l}\text { Obs } \\
(4)\end{array}$ & $\begin{array}{l}\text { Mean } \\
(5)\end{array}$ & $\begin{array}{l}\text { S.D. } \\
(6)\end{array}$ & $\begin{array}{l}\text { d } \\
(7)\end{array}$ & $\begin{array}{l}\text { t stat } \\
(8)\end{array}$ \\
\hline \multicolumn{10}{|l|}{ Baseline Survey in 1997} \\
\hline Age & Age (in years, integer) & 16925 & 8.898 & 5.246 & 25922 & 8.813 & 5.241 & 0.085 & 1.632 \\
\hline Male Dummy & Male Dummy: whether is male & 16925 & 0.494 & 0.500 & 25922 & 0.485 & 0.500 & 0.009 & 1.738 \\
\hline Household Size & Household size (integer) & 16925 & 7.227 & 2.408 & 25922 & 7.109 & 2.390 & 0.117 & 4.941 \\
\hline $\begin{array}{l}\text { Share of Children } \\
\text { Number of siblings }\end{array}$ & Young Percentage: Proportion of young members aged 18 or younger & 16925 & 0.156 & 0.059 & 25922 & 0.158 & 0.060 & -0.003 & -4.404 \\
\hline Aged $0-5$ & Number of siblings Aged $0-5$ (integer) & 16925 & 0.948 & 0.954 & 25922 & 0.940 & 0.957 & 0.008 & 0.867 \\
\hline Aged $6-13$ & Number of siblings Aged $6-13$ (integer) & 16925 & 1.593 & 1.209 & 25922 & 1.589 & 1.226 & 0.004 & 0.334 \\
\hline Aged $14-15$ & Number of siblings Aged $14-15$ (integer) & 16925 & 0.364 & 0.537 & 25922 & 0.342 & 0.523 & 0.021 & 4.107 \\
\hline Poverty Rate in 1997 & Poverty Rating Poverty score according to 1997 model & 16829 & 689.190 & 138.750 & 25922 & 682.708 & 134.652 & 6.483 & 4.805 \\
\hline Owns Car & Car Dummy: whether this household has a car & 16925 & 0.163 & 0.369 & 25922 & 0.152 & 0.359 & 0.010 & 2.902 \\
\hline Owns TV & TV Dummy: whether this household has a television & 16925 & 0.885 & 0.320 & 25922 & 0.871 & 0.335 & 0.014 & 4.155 \\
\hline Owns House & Owns House Dummy: whether this household owns house & 16925 & 0.985 & 0.123 & 25922 & 0.987 & 0.114 & -0.002 & -1.864 \\
\hline disabled member & Disabled Dummy: whether household has disabled members & 16920 & 0.052 & 0.221 & 25906 & 0.048 & 0.213 & 0.004 & 1.917 \\
\hline \multicolumn{10}{|c|}{$\begin{array}{l}\text { Outcome Variables in } 2017 \\
\text { Educational Attainments }\end{array}$} \\
\hline Education Years & Integer: individual's education year & 7725 & 8.347 & 3.218 & 12022 & 8.563 & 3.189 & -0.216 & -4.631 \\
\hline $\begin{array}{l}\text { Primary } \\
\text { Completion }\end{array}$ & Dummy: whether this individual graduates from primary school & 15878 & 0.432 & 0.495 & 24290 & 0.444 & 0.497 & -0.012 & -2.440 \\
\hline $\begin{array}{l}\text { Secondary } \quad \text { School } \\
\text { Completion }\end{array}$ & Dummy: whether this individual graduates from secondary school & 15878 & 0.295 & 0.456 & 24290 & 0.311 & 0.463 & -0.016 & -3.389 \\
\hline High School Completion & Dummy: whether this individual graduates from high school & 15878 & 0.096 & 0.295 & 24290 & 0.107 & 0.309 & -0.011 & -3.498 \\
\hline $\begin{array}{l}\text { Tertiary } \quad \text { School } \\
\text { Completion } \\
\text { Labour Market Performance }\end{array}$ & Dummy: whether this individual attend college or above & 15878 & 0.024 & 0.153 & 24290 & 0.027 & 0.161 & -0.003 & -1.559 \\
\hline Whether Working & Dummy: whether this individual is working & 16925 & 0.322 & 0.467 & 25922 & 0.333 & 0.471 & -0.010 & -2.208 \\
\hline $\begin{array}{l}\text { Whether Working for a } \\
\text { Salary }\end{array}$ & Dummy: whether this individual is working for a salary & 16925 & 0.216 & 0.411 & 25922 & 0.224 & 0.417 & -0.008 & -2.038 \\
\hline $\begin{array}{l}\text { Whether Working not for a } \\
\text { Salary }\end{array}$ & Dummy: whether this individual is working voluntarily & 16925 & 0.033 & 0.179 & 25922 & 0.040 & 0.195 & -0.006 & -3.343 \\
\hline
\end{tabular}


Log Weekly Salary L Log of Weekly salary

Log Monthly Salary Log of Monthly salary

Source: Authors' elaboration based on ENCASEH and ENCELs data 
Table 3: Unrestricted and Restricted Attrition Probit Model

\begin{tabular}{|c|c|c|c|c|c|c|}
\hline \multicolumn{7}{|c|}{ Dependent variable: Attrition dummy } \\
\hline & $\begin{array}{l}\text { Aggregate } \\
\text { Unrestricted } \\
\text { attrition_2017 } \\
\text { (1) }\end{array}$ & $\begin{array}{l}\text { Restricted } \\
\text { attrition_2017 } \\
\text { (2) }\end{array}$ & $\begin{array}{l}\text { Male } \\
\text { Unrestricted } \\
\text { attrition_2017 } \\
\text { (3) }\end{array}$ & $\begin{array}{l}\text { Restricted } \\
\text { attrition_2017 } \\
\text { (4) }\end{array}$ & $\begin{array}{l}\text { Female } \\
\text { Unrestricted } \\
\text { attrition_2017 } \\
\text { (5) }\end{array}$ & $\begin{array}{l}\text { Restricted } \\
\text { attrition_2017 } \\
\text { (6) }\end{array}$ \\
\hline \multirow{2}{*}{$\begin{array}{l}\text { Whether Treated in } \\
1997\end{array}$} & 0.0278 & 0.0233 & 0.0463 & 0.0241 & 0.0102 & 0.0183 \\
\hline & $(0.0271)$ & $(0.0271)$ & $(0.0303)$ & $(0.0315)$ & $(0.0339)$ & $(0.0307)$ \\
\hline \multirow[t]{2}{*}{ Age } & $0.00476 * * *$ & & $0.00485^{* * *}$ & & $0.00466^{* * *}$ & \\
\hline & $(0.000985)$ & & $(0.00118)$ & & $(0.00151)$ & \\
\hline \multicolumn{7}{|l|}{ Interactions } \\
\hline Treated*Age & $\begin{array}{l}-0.000217 \\
(0.00130)\end{array}$ & $\begin{array}{l}0.00525^{* * *} \\
(0.000779)\end{array}$ & $\begin{array}{l}-0.00104 \\
(0.00163)\end{array}$ & $\begin{array}{l}0.00421^{* * *} \\
(0.00110)\end{array}$ & $\begin{array}{l}0.000561 \\
(0.00190)\end{array}$ & $\begin{array}{l}0.00626 * * * \\
(0.00106)\end{array}$ \\
\hline Treated*Sibling 0-5 & $\begin{array}{l}0.00458 \\
(0.0138)\end{array}$ & $\begin{array}{l}-0.0397 * * * \\
(0.00849)\end{array}$ & $\begin{array}{l}-0.00469 \\
(0.0152)\end{array}$ & $\begin{array}{l}-0.0413 * * * \\
(0.0101)\end{array}$ & $\begin{array}{l}0.0136 \\
(0.0153)\end{array}$ & $\begin{array}{l}-0.0379 * * * \\
(0.00931)\end{array}$ \\
\hline Treated*Sibling 6-13 & $\begin{array}{l}-0.0128 \\
(0.00990)\end{array}$ & $\begin{array}{l}-0.0126 \\
(0.0106)\end{array}$ & $\begin{array}{l}-0.0121 \\
(0.0123)\end{array}$ & $\begin{array}{l}-0.00890 \\
(0.0134)\end{array}$ & $\begin{array}{l}-0.0135 \\
(0.0102)\end{array}$ & $\begin{array}{l}-0.0158 \\
(0.0109)\end{array}$ \\
\hline $\begin{array}{l}\text { Treated*Sibling } 14- \\
15\end{array}$ & $\begin{array}{l}0.00856 \\
(0.0205)\end{array}$ & $\begin{array}{l}-0.00314 \\
(0.0213)\end{array}$ & $\begin{array}{l}0.0158 \\
(0.0226)\end{array}$ & $\begin{array}{l}0.00539 \\
(0.0235)\end{array}$ & $\begin{array}{l}0.00192 \\
(0.0237)\end{array}$ & $\begin{array}{l}-0.0105 \\
(0.0246)\end{array}$ \\
\hline \multicolumn{7}{|l|}{ Number of siblings } \\
\hline Aged 0 - 5 & $\begin{array}{l}-0.0320 * * * \\
(0.0109)\end{array}$ & & $\begin{array}{l}-0.0226^{*} \\
(0.0119)\end{array}$ & & $\begin{array}{l}-0.0413^{* * *} \\
(0.0123)\end{array}$ & \\
\hline Aged $6-13$ & $\begin{array}{l}0.00606 \\
(0.00925)\end{array}$ & $\begin{array}{l}-0.00852 \\
(0.00864)\end{array}$ & $\begin{array}{l}0.00674 \\
(0.0106)\end{array}$ & $\begin{array}{l}-0.0127 \\
(0.0100)\end{array}$ & $\begin{array}{l}0.00538 \\
(0.0103)\end{array}$ & $\begin{array}{l}-0.00468 \\
(0.0102)\end{array}$ \\
\hline Aged $14-15$ & $\begin{array}{l}0.0137 \\
(0.0183)\end{array}$ & $\begin{array}{l}0.0185 \\
(0.0184)\end{array}$ & $\begin{array}{l}0.0133 \\
(0.0186)\end{array}$ & $\begin{array}{l}0.0144 \\
(0.0185)\end{array}$ & $\begin{array}{l}0.0136 \\
(0.0219)\end{array}$ & $\begin{array}{l}0.0222 \\
(0.0219)\end{array}$ \\
\hline \multicolumn{7}{|c|}{ Province: Compared with Guerrero } \\
\hline Hidalgo & $\begin{array}{l}0.0662 \\
(0.0463)\end{array}$ & $\begin{array}{l}-0.0396 \\
(0.0331)\end{array}$ & $\begin{array}{l}0.0768 * \\
(0.0439)\end{array}$ & & $\begin{array}{l}0.0556 \\
(0.0508)\end{array}$ & $\begin{array}{l}-0.0396 \\
(0.0349)\end{array}$ \\
\hline Michoacán & $\begin{array}{l}0.122 * * \\
(0.0514)\end{array}$ & & $\begin{array}{l}0.132 * * \\
(0.0517)\end{array}$ & & $\begin{array}{l}0.113 * * \\
(0.0544)\end{array}$ & \\
\hline Puebla & $\begin{array}{l}0.0242 \\
(0.0488)\end{array}$ & $\begin{array}{l}-0.0773^{* *} \\
(0.0376)\end{array}$ & $\begin{array}{l}0.0522 \\
(0.0490)\end{array}$ & $\begin{array}{l}-0.0549 \\
(0.0367)\end{array}$ & $\begin{array}{l}-0.00315 \\
(0.0502)\end{array}$ & $\begin{array}{l}-0.0927 * * \\
(0.0391)\end{array}$ \\
\hline Querétaro & $\begin{array}{l}0.141 * * \\
(0.0649)\end{array}$ & & $\begin{array}{l}0.140 * * \\
(0.0686)\end{array}$ & & $\begin{array}{l}0.145^{* *} \\
(0.0637)\end{array}$ & \\
\hline San Luis Potosí & $\begin{array}{l}0.104 * * \\
(0.0442)\end{array}$ & & $\begin{array}{l}0.117 * * * \\
(0.0445)\end{array}$ & & $\begin{array}{l}0.0922 * * \\
(0.0457)\end{array}$ & \\
\hline Veracruz & $\begin{array}{l}0.164 * * * \\
(0.0440)\end{array}$ & & $\begin{array}{l}0.175^{* * *} \\
(0.0428)\end{array}$ & & $\begin{array}{l}0.155^{* * * *} \\
(0.0473)\end{array}$ & \\
\hline Household Size & $\begin{array}{l}-0.00303 \\
(0.00620)\end{array}$ & $\begin{array}{l}-0.0296 * * * \\
(0.00420)\end{array}$ & $\begin{array}{l}-0.000109 \\
(0.00687)\end{array}$ & $\begin{array}{l}-0.0268^{* * * *} \\
(0.00451)\end{array}$ & $\begin{array}{l}-0.00637 \\
(0.00696)\end{array}$ & $\begin{array}{l}-0.0323 * * * \\
(0.00485)\end{array}$ \\
\hline Share of Children & $\begin{array}{l}1.044 * * * \\
(0.225)\end{array}$ & & $\begin{array}{l}1.156^{* * * *} \\
(0.249)\end{array}$ & & $\begin{array}{l}0.921 * * * \\
(0.270)\end{array}$ & \\
\hline Whether Owns TV & $\begin{array}{l}-0.313 * * * \\
(0.0228)\end{array}$ & & $\begin{array}{l}-0.305^{* * *} \\
(0.0242)\end{array}$ & & $\begin{array}{l}-0.322 * * * \\
(0.0242)\end{array}$ & \\
\hline Whether Owns Car & $\begin{array}{l}-0.107^{* * *} \\
(0.0180)\end{array}$ & & $\begin{array}{l}-0.0943 * * * \\
(0.0204)\end{array}$ & & $\begin{array}{l}-0.121^{* * *} \\
(0.0187)\end{array}$ & \\
\hline
\end{tabular}




\begin{tabular}{|c|c|c|c|c|c|c|}
\hline \multirow[t]{2}{*}{$\begin{array}{l}\text { Whether } \\
\text { House }\end{array}$} & $-0.344 * * *$ & & $-0.390 * * *$ & & $-0.307 * * *$ & \\
\hline & $(0.0530)$ & & $(0.0666)$ & & $(0.0547)$ & \\
\hline \multirow[t]{2}{*}{$\begin{array}{l}\text { Whether with } \\
\text { disabled member }\end{array}$} & -0.00683 & 0.00516 & -0.0196 & -0.0110 & 0.00534 & 0.0187 \\
\hline & $(0.0234)$ & $(0.0246)$ & $(0.0276)$ & $(0.0285)$ & $(0.0243)$ & $(0.0269)$ \\
\hline \multirow[t]{2}{*}{ Poverty Rate in 1997} & $0.000318^{* * * *}$ & & $0.000364 * * *$ & & $0.000271^{* *}$ & \\
\hline & $(0.000106)$ & & $(0.000106)$ & & $(0.000116)$ & \\
\hline $\mathrm{N}$ & 29774 & 29774 & 14589 & 14589 & 15185 & 15185 \\
\hline
\end{tabular}

Notes: Standard errors are clustered at the village level. Robust standard errors in parentheses: * $\mathrm{p}<0.10 * * \mathrm{p}<0.05 * * * \mathrm{p}<0.01$ Source: Authors' elaboration based on ENCASEH and ENCEL data. 
Table 4: Overall Balancing Measures after Kernel Matching

\begin{tabular}{|c|c|c|c|c|c|c|c|c|}
\hline Aggregate & Ps R2 & LR chi2 & $\mathrm{p}>$ chi 2 & MeanBias & MedBias & Rubin'sB & Rubin'sR & $\% \mathrm{Var}$ \\
\hline Unmatched & 0.001 & 22.8 & 0.007 & 0.9 & 0.6 & 5.9 & 1.2 & 50 \\
\hline Matched & 0.001 & 59.6 & 0 & 1.5 & 1.8 & 8.3 & 1.54 & 67 \\
\hline \multicolumn{9}{|l|}{ Male } \\
\hline Unmatched & 0.001 & 11.59 & 0.238 & 1.3 & 1 & 6 & 1.24 & 17 \\
\hline Matched & 0 & 10.85 & 0.286 & 1.3 & 1.5 & 5.1 & 1.16 & 67 \\
\hline \multicolumn{9}{|l|}{ Female } \\
\hline Unmatched & 0.001 & 19.28 & 0.023 & 1.9 & 1.8 & 7.6 & 1.09 & 50 \\
\hline Matched & 0.002 & 60.34 & 0 & 1.6 & 1.1 & 11.6 & 1.43 & 67 \\
\hline
\end{tabular}

Source: Authors' elaboration based on ENCASEH and ENCELs data. 
Table 5: Long-term Impacts (ITT) of PROGRESA on Education and Labour Market: PSM

\begin{tabular}{|c|c|c|c|c|c|c|c|c|c|c|c|c|c|c|c|}
\hline \multirow[b]{2}{*}{ Outcome Variable } & \multicolumn{12}{|c|}{ POOR (ITT) } & \multicolumn{3}{|c|}{$\begin{array}{l}\text { NON-POOR (Spillover effect) } \\
\text { Total Sample (aged 0-18 in 1997) }\end{array}$} \\
\hline & $\begin{array}{l}\text { Total Sam } \\
\text { Aggregate } \\
(1)\end{array}$ & $\begin{array}{l}\text { e (aged } 0 \\
\text { Male } \\
(2)\end{array}$ & $\begin{array}{l}8 \text { in 1997) } \\
\text { Female } \\
(3)\end{array}$ & $\begin{array}{l}\text { 13-18 } \\
\text { Aggregate } \\
\text { (4) }\end{array}$ & $\begin{array}{l}\text { Male } \\
(5)\end{array}$ & $\begin{array}{l}\text { Female } \\
\text { (6) }\end{array}$ & $\begin{array}{l}\text { 6-12 } \\
\text { Aggregate } \\
\text { (7) } \\
\end{array}$ & $\begin{array}{l}\text { Male } \\
(8)\end{array}$ & $\begin{array}{l}\text { Female } \\
(9)\end{array}$ & $\begin{array}{l}0-5 \\
\text { Aggregate } \\
(10)\end{array}$ & $\begin{array}{l}\text { Male } \\
(11)\end{array}$ & $\begin{array}{l}\text { Female } \\
(12)\end{array}$ & $\begin{array}{l}\text { Total Sam } \\
\text { Aggregate } \\
(13)\end{array}$ & $\begin{array}{l}\text { le (aged } 0 \\
\text { Male } \\
(14)\end{array}$ & $\begin{array}{l}18 \text { in 1997) } \\
\text { Female } \\
(15)\end{array}$ \\
\hline Educational attainment & & & & & & & & & & & & & & & \\
\hline Education Years & $\begin{array}{l}0.227 * * * \\
(0.054)\end{array}$ & $\begin{array}{l}0.196 * * \\
(0.077)\end{array}$ & $\begin{array}{l}0.254 * * * * \\
(0.075)\end{array}$ & $\begin{array}{l}0.268^{* *} \\
(0.112)\end{array}$ & $\begin{array}{l}0.199 \\
(0.161)\end{array}$ & $\begin{array}{l}0.300^{*} \\
(0.157)\end{array}$ & $\begin{array}{l}0.242 * * * \\
(0.080)\end{array}$ & $\begin{array}{l}0.302^{* * * *} \\
(0.116)\end{array}$ & $\begin{array}{l}0.175 \\
(0.112)\end{array}$ & $\begin{array}{l}0.180 * * \\
(0.089)\end{array}$ & $\begin{array}{l}0.101 \\
(0.124)\end{array}$ & $\begin{array}{l}0.280 * * \\
(0.128)\end{array}$ & $\begin{array}{l}0.252 * * * \\
(0.094)\end{array}$ & $\begin{array}{l}0.140 \\
(0.141)\end{array}$ & $\begin{array}{l}0.288 * * \\
(0.129)\end{array}$ \\
\hline Primary School Completion & $\begin{array}{l}0.012 * * \\
(0.006)\end{array}$ & $\begin{array}{l}0.005 \\
(0.009)\end{array}$ & $\begin{array}{l}0.023^{* * *} \\
(0.009)\end{array}$ & $\begin{array}{l}0.021 * \\
(0.012)\end{array}$ & $\begin{array}{l}0.014 \\
(0.017)\end{array}$ & $\begin{array}{l}0.035 * * \\
(0.017)\end{array}$ & $\begin{array}{l}0.016 * \\
(0.009)\end{array}$ & $\begin{array}{l}0.015 \\
(0.013)\end{array}$ & $\begin{array}{l}0.020^{*} \\
(0.013)\end{array}$ & $\begin{array}{l}0.002 \\
(0.011)\end{array}$ & $\begin{array}{l}-0.006 \\
(0.016)\end{array}$ & $\begin{array}{l}0.010 \\
(0.016)\end{array}$ & $\begin{array}{l}0.002 \\
(0.009)\end{array}$ & $\begin{array}{l}0.010 \\
(0.013)\end{array}$ & $\begin{array}{l}-0.002 \\
(0.013)\end{array}$ \\
\hline Secondary School Completion & $\begin{array}{l}0.018 \text { *** } \\
(0.006)\end{array}$ & $\begin{array}{l}0.015^{*} \\
(0.008)\end{array}$ & $\begin{array}{l}0.023 * * * \\
(0.008)\end{array}$ & $\begin{array}{l}0.016 * \\
(0.010)\end{array}$ & $\begin{array}{l}0.010 \\
(0.014)\end{array}$ & $\begin{array}{l}0.025^{*} \\
(0.014)\end{array}$ & $\begin{array}{l}0.025 * * * \\
(0.009)\end{array}$ & $\begin{array}{l}0.039^{* * * *} \\
(0.012)\end{array}$ & $\begin{array}{l}0.013 \\
(0.012)\end{array}$ & $\begin{array}{l}0.010 \\
(0.011)\end{array}$ & $\begin{array}{l}-0.008 \\
(0.016)\end{array}$ & $\begin{array}{l}0.027^{*} \\
(0.015)\end{array}$ & $\begin{array}{l}0.005 \\
(0.008)\end{array}$ & $\begin{array}{l}-0.001 \\
(0.012)\end{array}$ & $\begin{array}{l}0.011 \\
(0.011)\end{array}$ \\
\hline High School Completion & $\begin{array}{l}0.007 * \\
(0.004)\end{array}$ & $\begin{array}{l}0.009 \\
(0.005)\end{array}$ & $\begin{array}{l}0.006 \\
(0.005)\end{array}$ & $\begin{array}{l}0.001 \\
(0.005)\end{array}$ & $\begin{array}{l}(0.001) \\
(0.007)\end{array}$ & $\begin{array}{l}0.001 \\
(0.007)\end{array}$ & $\begin{array}{l}0.008 \\
(0.005)\end{array}$ & $\begin{array}{l}0.020^{* * * *} \\
(0.008)\end{array}$ & $\begin{array}{l}(0.003) \\
(0.008)\end{array}$ & $\begin{array}{l}0.010 \\
(0.008)\end{array}$ & $\begin{array}{l}0.002 \\
(0.012)\end{array}$ & $\begin{array}{l}0.020 * \\
(0.011)\end{array}$ & $\begin{array}{l}0.018^{* * * *} \\
(0.005)\end{array}$ & $\begin{array}{l}0.013 \\
(0.008)\end{array}$ & $\begin{array}{l}0.020^{\text {**** }} \\
(0.007)\end{array}$ \\
\hline Tertiary School Completion & $\begin{array}{l}0.003 * \\
(0.002)\end{array}$ & $\begin{array}{l}0.004 \\
(0.003)\end{array}$ & $\begin{array}{l}0.002 \\
(0.002)\end{array}$ & $\begin{array}{l}0.005^{* *} \\
(0.002)\end{array}$ & $\begin{array}{l}0.006 * \\
(0.003)\end{array}$ & $\begin{array}{l}0.002 \\
(0.003)\end{array}$ & $\begin{array}{l}0.005 * * \\
(0.003)\end{array}$ & $\begin{array}{l}0.007 * \\
(0.004)\end{array}$ & $\begin{array}{l}0.004 \\
(0.003)\end{array}$ & $\begin{array}{l}-0.001 \\
(0.004)\end{array}$ & $\begin{array}{l}-0.001 \\
(0.006)\end{array}$ & $\begin{array}{l}-0.001 \\
(0.006)\end{array}$ & $\begin{array}{l}0.002 \\
(0.003)\end{array}$ & $\begin{array}{l}0.000 \\
(0.005)\end{array}$ & $\begin{array}{l}0.003 \\
(0.004)\end{array}$ \\
\hline Labour Market Performance & & & & & & & & & & & & & & & \\
\hline Whether Working or not & $\begin{array}{l}0.015 * * * \\
(0.006)\end{array}$ & $\begin{array}{l}0.013^{*} \\
(0.007)\end{array}$ & $\begin{array}{l}0.018^{* *} \\
(0.008)\end{array}$ & $\begin{array}{l}0.003 \\
(0.012)\end{array}$ & $\begin{array}{l}(0.001) \\
(0.015)\end{array}$ & $\begin{array}{l}0.014 \\
(0.017)\end{array}$ & $\begin{array}{l}0.016^{*} \\
(0.009)\end{array}$ & $\begin{array}{l}0.024 * * \\
(0.011)\end{array}$ & $\begin{array}{l}0.009 \\
(0.013)\end{array}$ & $\begin{array}{l}0.021 \text { ** } \\
(0.010)\end{array}$ & $\begin{array}{l}0.013 \\
(0.012)\end{array}$ & $\begin{array}{l}0.028 * \\
(0.015)\end{array}$ & $\begin{array}{l}-0.010 \\
(0.008)\end{array}$ & $\begin{array}{l}-0.017 \\
(0.010)\end{array}$ & $\begin{array}{l}0.002 \\
(0.012)\end{array}$ \\
\hline Whether Working for a Salary & $\begin{array}{l}0.010 * \\
(0.005)\end{array}$ & $\begin{array}{l}0.005 \\
(0.005)\end{array}$ & $\begin{array}{l}0.015^{*} \\
(0.008)\end{array}$ & $\begin{array}{l}0.014 \\
(0.010)\end{array}$ & $\begin{array}{l}0.021 * * \\
(0.011)\end{array}$ & $\begin{array}{l}0.009 \\
(0.016)\end{array}$ & $\begin{array}{l}0.002 \\
(0.008)\end{array}$ & $\begin{array}{l}-0.001 \\
(0.008)\end{array}$ & $\begin{array}{l}-0.001 \\
(0.012)\end{array}$ & $\begin{array}{l}0.018 \text { ** } \\
(0.009)\end{array}$ & $\begin{array}{l}0.001 \\
(0.010)\end{array}$ & $\begin{array}{l}0.032 * * \\
(0.014)\end{array}$ & $\begin{array}{l}-0.001 \\
(0.007)\end{array}$ & $\begin{array}{l}0.000 \\
(0.007)\end{array}$ & $\begin{array}{l}0.002 \\
(0.011)\end{array}$ \\
\hline Whether Working Voluntarily & $\begin{array}{l}0.006 * * * \\
(0.002)\end{array}$ & $\begin{array}{l}0.005 \\
(0.003)\end{array}$ & $\begin{array}{l}0.007 \text { ** } \\
(0.003)\end{array}$ & $\begin{array}{l}-0.002 \\
(0.005)\end{array}$ & $\begin{array}{l}-0.006 \\
(0.007)\end{array}$ & $\begin{array}{l}0.002 \\
(0.007)\end{array}$ & $\begin{array}{l}0.009 * * \\
(0.003)\end{array}$ & $\begin{array}{l}0.011^{* *} \\
(0.005)\end{array}$ & $\begin{array}{l}0.009 * \\
(0.005)\end{array}$ & $\begin{array}{l}0.007 \text { ** } \\
(0.004)\end{array}$ & $\begin{array}{l}0.007 \\
(0.005)\end{array}$ & $\begin{array}{l}0.008 \\
(0.005)\end{array}$ & $\begin{array}{l}0.006^{*} \\
(0.003)\end{array}$ & $\begin{array}{l}0.000 \\
(0.005)\end{array}$ & $\begin{array}{l}0.013^{* * * *} \\
(0.004)\end{array}$ \\
\hline Log Salary (weekly) & $\begin{array}{l}0.045^{* *} \\
(0.021)\end{array}$ & $\begin{array}{l}-0.019 \\
(0.047)\end{array}$ & $\begin{array}{l}0.063^{* * * *} \\
(0.023)\end{array}$ & $\begin{array}{l}0.088^{*} \\
(0.053)\end{array}$ & $\begin{array}{l}0.067 \\
(0.126)\end{array}$ & $\begin{array}{l}0.092^{*} \\
(0.055)\end{array}$ & $\begin{array}{l}0.016 \\
(0.033)\end{array}$ & $\begin{array}{l}-0.055 \\
(0.071)\end{array}$ & $\begin{array}{l}0.051 \\
(0.037)\end{array}$ & $\begin{array}{l}0.050 \\
(0.033)\end{array}$ & $\begin{array}{l}-0.015 \\
(0.070)\end{array}$ & $\begin{array}{l}0.065 * \\
(0.037)\end{array}$ & $\begin{array}{l}-0.069^{*} \\
(0.036)\end{array}$ & $\begin{array}{l}-0.007 \\
(0.080)\end{array}$ & $\begin{array}{l}-0.111^{* * *} \\
(0.039)\end{array}$ \\
\hline Log Salary (monthly) & $\begin{array}{l}0.054 * * \\
(0.027)\end{array}$ & $\begin{array}{l}0.083 * * \\
(0.038)\end{array}$ & $\begin{array}{l}0.039 \\
(0.037)\end{array}$ & $\begin{array}{l}0.077 \\
(0.058)\end{array}$ & $\begin{array}{l}0.123 \\
(0.081)\end{array}$ & $\begin{array}{l}0.045 \\
(0.084)\end{array}$ & $\begin{array}{l}0.043 \\
(0.039)\end{array}$ & $\begin{array}{l}0.109 * * \\
(0.057)\end{array}$ & $\begin{array}{l}-0.011 \\
(0.054)\end{array}$ & $\begin{array}{l}0.066 \\
(0.046)\end{array}$ & $\begin{array}{l}-0.013 \\
(0.071)\end{array}$ & $\begin{array}{l}0.105^{*} \\
(0.062)\end{array}$ & $\begin{array}{l}-0.025 \\
(0.039)\end{array}$ & $\begin{array}{l}-0.049 \\
(0.059)\end{array}$ & $\begin{array}{l}-0.014 \\
(0.054)\end{array}$ \\
\hline
\end{tabular}

Notes: Standard errors are clustered at the village level; Marginal effect $(d y / d x)$ is reported for Probit models.; Robust standard errors in parentheses; * $\mathrm{p}<0.10 * * \mathrm{p}<0.05 * * * \mathrm{p}<0.01$. Statistically significant cases are highlighted in bold; See Online Appendix Tables 3.1-3.6 for the number of observations in each case.

Source: Authors' elaboration based on ENCASEH and ENCELs data. 
Table 6: Full Unconditional Quantile Estimations: with general and report Attrition Corrected

\begin{tabular}{|c|c|c|c|c|c|c|c|c|c|c|c|c|c|c|c|c|}
\hline & & \multicolumn{12}{|c|}{ POOR (ITT) } & \multicolumn{3}{|c|}{$\begin{array}{l}\text { NON-POOR (Spillover effect) } \\
\text { Total Sample (aged 0-18 in 1997) }\end{array}$} \\
\hline & & $\begin{array}{l}\text { Aggregate } \\
\text { (1) }\end{array}$ & $\begin{array}{l}\text { Male } \\
\text { (2) }\end{array}$ & $\begin{array}{l}\text { Female } \\
\text { (3) }\end{array}$ & $\begin{array}{l}\text { Aggregate } \\
\text { (4) }\end{array}$ & $\begin{array}{l}\text { Male } \\
(5)\end{array}$ & $\begin{array}{l}\text { Female } \\
\text { (6) }\end{array}$ & $\begin{array}{l}\text { Aggregate } \\
\text { (7) }\end{array}$ & $\begin{array}{l}\text { Male } \\
\text { (8) }\end{array}$ & $\begin{array}{l}\text { Female } \\
\text { (9) }\end{array}$ & $\begin{array}{l}\text { Aggregate } \\
\text { (10) }\end{array}$ & $\begin{array}{l}\text { Male } \\
\text { (11) }\end{array}$ & $\begin{array}{l}\text { Female } \\
\text { (12) }\end{array}$ & $\begin{array}{l}\text { Aggregate } \\
\text { (13) }\end{array}$ & $\begin{array}{l}\text { Male } \\
(14)\end{array}$ & $\begin{array}{l}\text { Female } \\
\text { (15) }\end{array}$ \\
\hline \multirow{9}{*}{ Education Years } & \multirow[t]{2}{*}{10} & $0.133^{* * * *}$ & $0.182^{* * *}$ & $0.159 * * *$ & 0.692 & 0.292 & 0.842 & $0.148 * * * *$ & 0.0555 & $0.222 * * *$ & 0.0752 & 0.185 & 0.0198 & 0.0259 & 0.0490 & 0.0170 \\
\hline & & $(\mathbf{0 . 0 3 2 1})$ & $(0.0877)$ & $(0.0451)$ & $(0.438)$ & $(0.671)$ & $(0.587)$ & $(0.0557)$ & $(0.104)$ & $(0.0787)$ & $(0.0976)$ & $(0.156)$ & $(0.129)$ & $(0.0930)$ & $(0.169)$ & $(0.122)$ \\
\hline & 25 & $0.133^{* * * *}$ & $0.182^{* * *}$ & $0.159 * * *$ & $0.274 * * *$ & 0.176 & $0.362 * * * *$ & $0.148 * * *$ & 0.0555 & $0.222 * * * *$ & 0.479 & 0.202 & 0.0198 & 0.0259 & 0.0490 & 0.0170 \\
\hline & \multirow[t]{2}{*}{50} & $0.104 * * *$ & $0.252 * * *$ & $0.0953 * *$ & $0.274 * * *$ & 0.176 & $0.362 * * *$ & 0.0770 & 0.145 & 0.0651 & $0.172 * *$ & 0.202 & $0.178^{*}$ & 0.0584 & -0.168 & 0.173 \\
\hline & & $(0.0312)$ & $(\mathbf{0 . 0 9 3 5 )}$ & $(0.0419)$ & $(0.0791)$ & $(0.142)$ & $(0.115)$ & $(0.0547)$ & $(0.108)$ & $(0.0749)$ & $(\mathbf{0 . 0 7 8 1 )}$ & $(0.128)$ & $(0.101)$ & $(0.0898)$ & $(0.182)$ & $(0.114)$ \\
\hline & \multirow[t]{2}{*}{75} & $0.104 * * *$ & $0.843 * *$ & $0.0953 * *$ & $0.237 * *$ & $0.380^{*}$ & 0.196 & 0.0770 & 0.145 & 0.0651 & $0.317^{* * *}$ & 0.170 & $1.073 * * * *$ & $0.775 * * *$ & $0.622 * *$ & $1.063^{* * * *}$ \\
\hline & & $(0.0312)$ & $(\mathbf{0 . 3 3 3})$ & $(0.0419)$ & $(0.109)$ & $(0.224)$ & $(0.148)$ & $(0.0547)$ & $(0.108)$ & $(0.0749)$ & (0.136) & $(0.187)$ & $(0.371)$ & $(0.176)$ & $(\mathbf{0 . 3 0 7})$ & $(0.229)$ \\
\hline & \multirow[t]{2}{*}{90} & $0.194 * * *$ & $0.471^{* * * *}$ & $0.177^{*}$ & 0.490 & 0.641 & 0.219 & 0.196 & $0.615 * *$ & 0.0151 & $0.317 * *$ & 0.170 & $0.497 * * *$ & $0.775 * * *$ & 0.144 & $1.070^{* * * *}$ \\
\hline & & $(0.0642)$ & (0.174) & $(0.0912)$ & $(0.315)$ & $(0.395)$ & $(0.336)$ & $(0.129)$ & $(0.253)$ & $(0.179)$ & (0.136) & $(0.187)$ & $(0.192)$ & $(0.176)$ & $(0.369)$ & $(0.244)$ \\
\hline \multirow{9}{*}{ Log Salary (monthly) } & 10 & $0.289 * * *$ & $0.405^{* * * *}$ & $0.205 * *$ & $0.274 *$ & 0.138 & 0.276 & $0.205 * *$ & $0.449 * * * *$ & 0.00391 & $0.439 * * *$ & $0.371^{*}$ & $0.394 * * * *$ & $0.262 * *$ & 0.278 & 0.247 \\
\hline & \multirow[t]{2}{*}{25} & 0.0424 & 0.0685 & 0.0190 & $0.141 *$ & 0.176 & 0.112 & -0.0314 & 0.0357 & -0.101 & 0.0676 & 0.0197 & 0.101 & 0.0654 & 0.108 & 0.0612 \\
\hline & & $(0.0353)$ & $(0.0508)$ & $(0.0514)$ & $(0.0818)$ & $(0.122)$ & $(0.117)$ & $(0.0557)$ & $(0.0789)$ & $(0.0810)$ & $(0.0621)$ & $(0.0907)$ & $(0.0889)$ & $(0.0448)$ & $(0.0789)$ & $(0.0574)$ \\
\hline & \multirow[t]{2}{*}{50} & -0.00763 & 0.0103 & -0.0209 & 0.0553 & $0.146^{*}$ & -0.0349 & $-0.0700 *$ & -0.0287 & $-0.101 *$ & 0.0307 & -0.0510 & 0.0693 & -0.0404 & $-0.112^{*}$ & 0.00363 \\
\hline & & $(0.0245)$ & $(0.0381)$ & $(0.0335)$ & $(0.0614)$ & $(0.0851)$ & $(0.0878)$ & $(\mathbf{0 . 0 3 7 7 )}$ & $(0.0561)$ & $(0.0522)$ & $(0.0415)$ & $(0.0713)$ & $(0.0538)$ & $(0.0360)$ & $(0.0574)$ & $(0.0483)$ \\
\hline & \multirow[t]{2}{*}{75} & -0.0124 & 0.0350 & $-0.0614^{*}$ & -0.0289 & 0.0791 & -0.127 & -0.0207 & 0.0300 & -0.0718 & -0.00178 & 0.00305 & -0.00625 & $-0.0660 *$ & $-0.108^{*}$ & -0.0349 \\
\hline & & $(0.0249)$ & $(0.0355)$ & $(\mathbf{0 . 0 3 3 5})$ & $(0.0532)$ & $(0.0663)$ & $(0.0861)$ & $(0.0387)$ & $(0.0577)$ & $(0.0515)$ & $(0.0410)$ & $(0.0677)$ & $(0.0537)$ & $(\mathbf{0 . 0 3 5 8 )}$ & $(0.0590)$ & $(0.0464)$ \\
\hline & \multirow[t]{2}{*}{90} & $-0.0619 * *$ & -0.00552 & $-0.102 * * *$ & -0.0879 & 0.0535 & $-0.213 * *$ & -0.0364 & 0.0215 & -0.0751 & -0.0680 & -0.0690 & -0.0671 & -0.0433 & 0.00318 & -0.0608 \\
\hline & & $(0.0294)$ & $(0.0465)$ & $(0.0389)$ & $(0.0642)$ & $(0.0738)$ & $(0.101)$ & $(0.0459)$ & $(0.0731)$ & $(0.0597)$ & $(0.0498)$ & $(0.0893)$ & $(0.0537)$ & $(0.0488)$ & $(0.0869)$ & $(0.0591)$ \\
\hline
\end{tabular}

Notes: Figures in parentheses are robust standard errors; *** $\mathrm{p}<0.01,{ }^{* *} \mathrm{p}<0.05,{ }^{*} \mathrm{p}<0.10$; See Online Appendix Tables 3.1-3.6 for the number of observations in each case; Source: Authors' elaboration based on ENCASEH and ENCELs data. 
Figure 1: Data and PROGRESA policy evolution

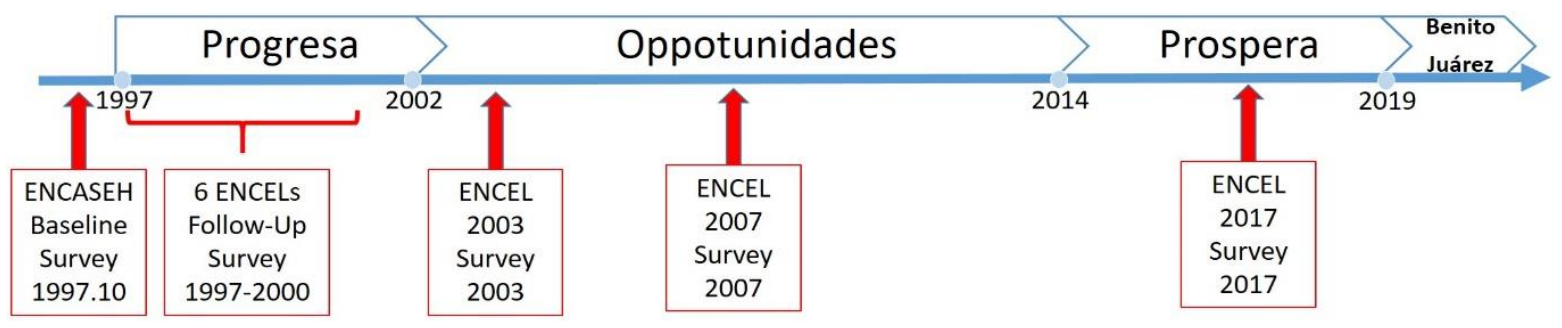

Source: Authors' update from Mexican Federal Government https://www.gob.mx/

Figure 2a: Regions in common support after Kernel Matching - All poor sample 0-18

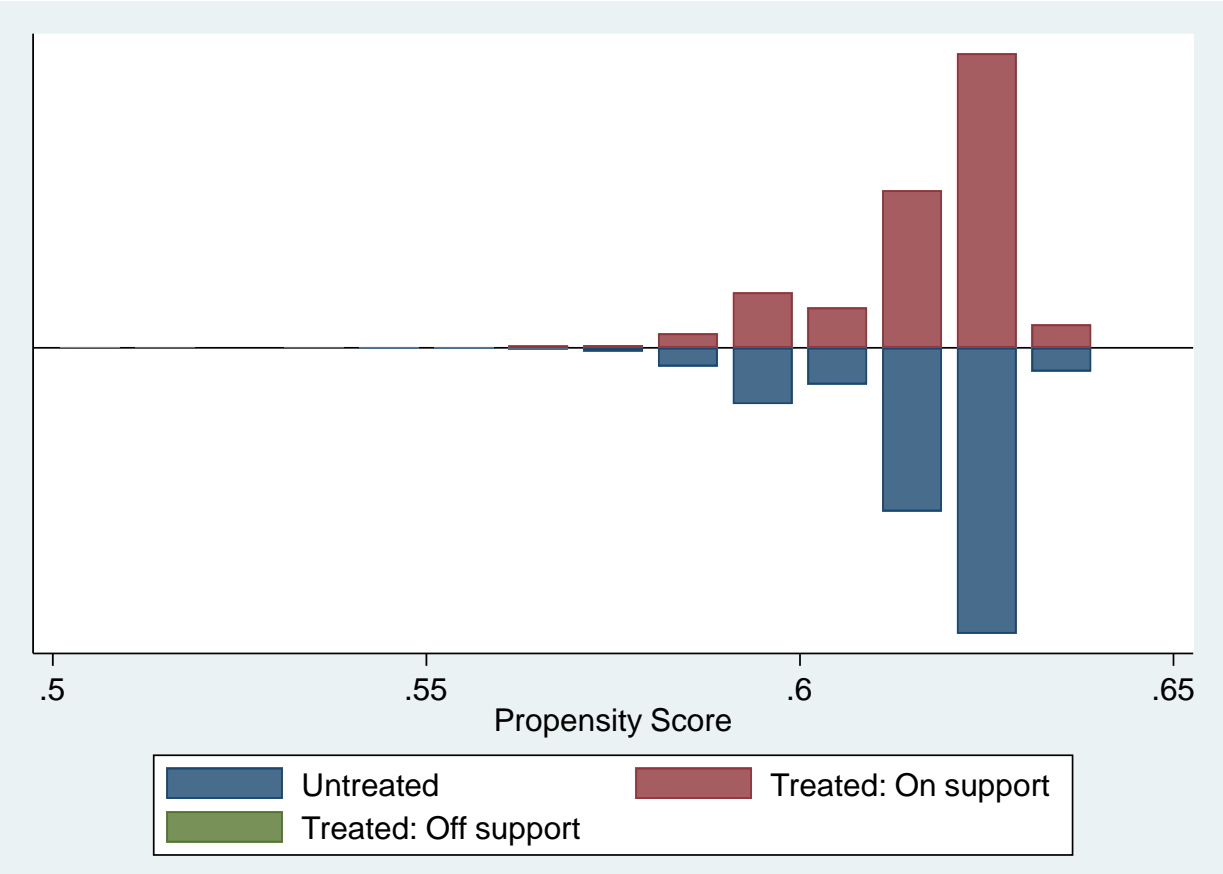

Source: Authors' elaboration based on ENCASEH and ENCELs data. 
Figure 2-b: Regions in common support after Kernel Matching - Male poor sample 0-18

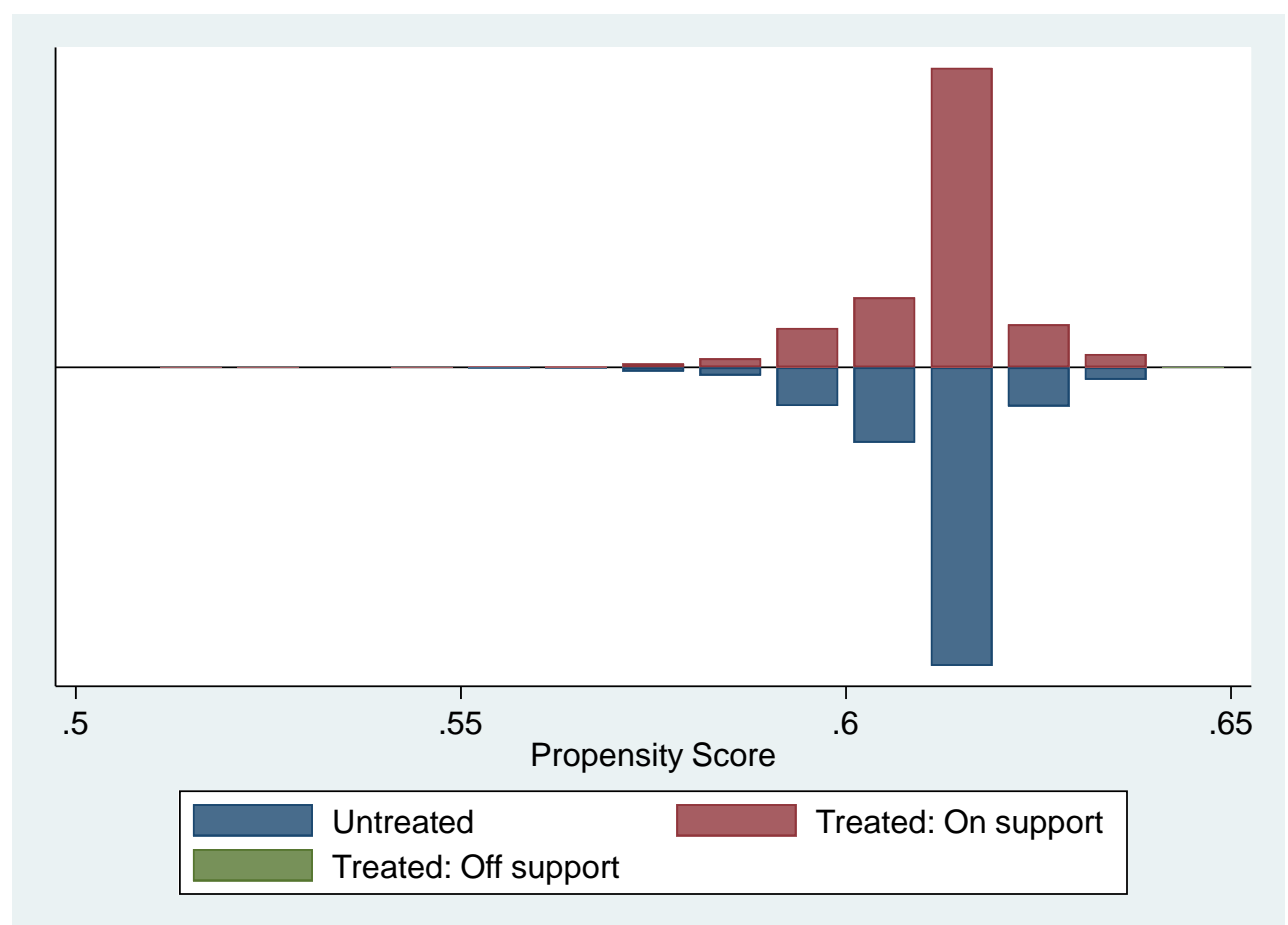

Source: Authors' elaboration based on ENCASEH and ENCELs data

Figure 2-c: Regions in common support after Kernel Matching - Female poor sample 0-18

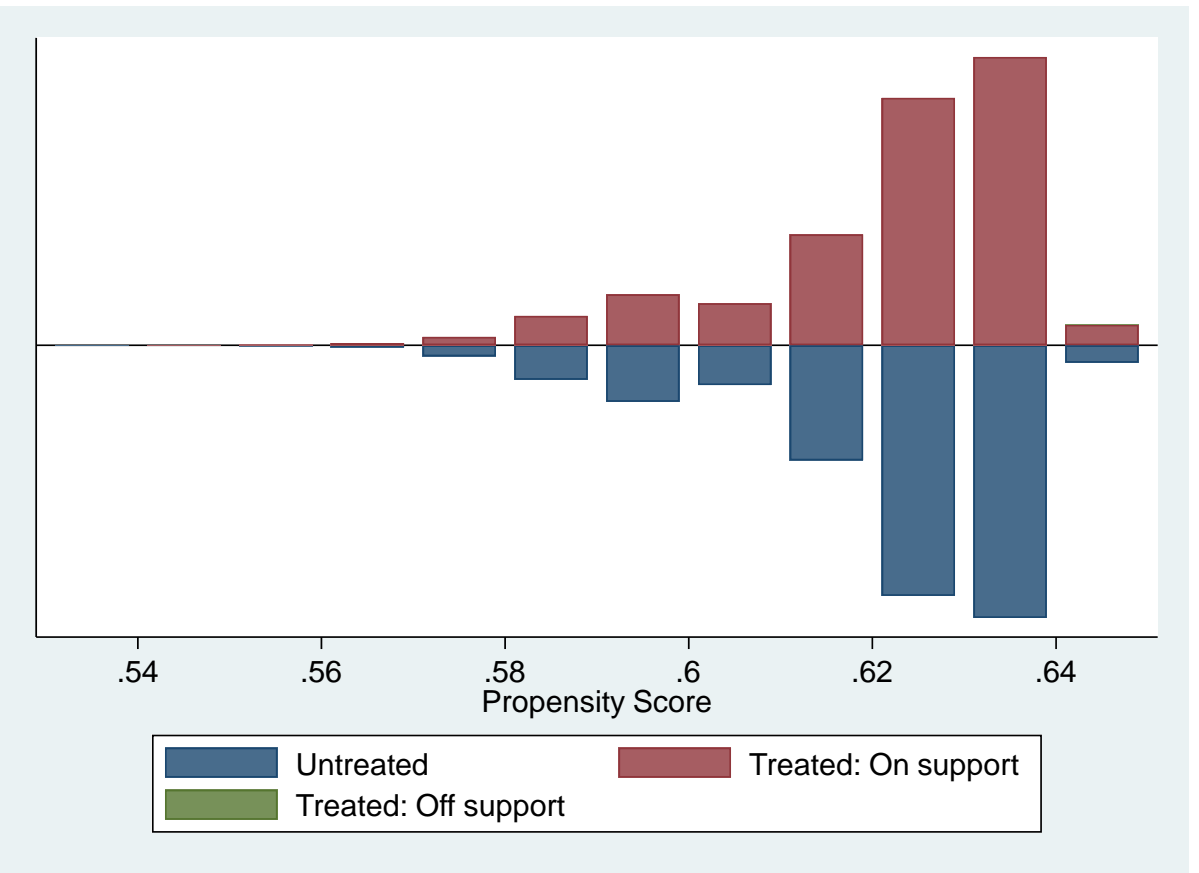

Source: Authors' elaboration based on ENCASEH and ENCELs data. 
Figure 3-a: Distribution of PS across Treatment and Comparison Groups - All sample 0-18

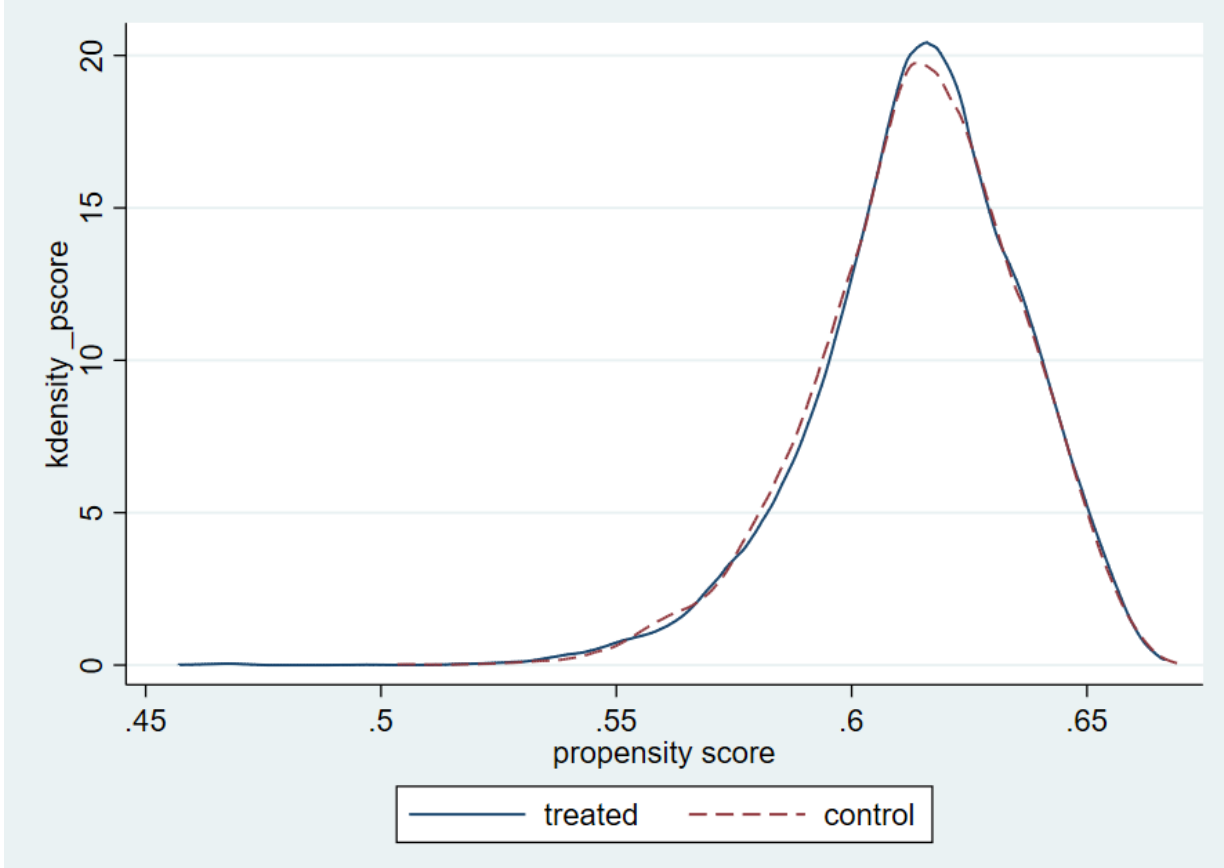

Source: Authors' elaboration based on ENCASEH and ENCEL data

Figure 3-b: Distribution of PS across Treatment and Comparison Groups - Male sample 0-18

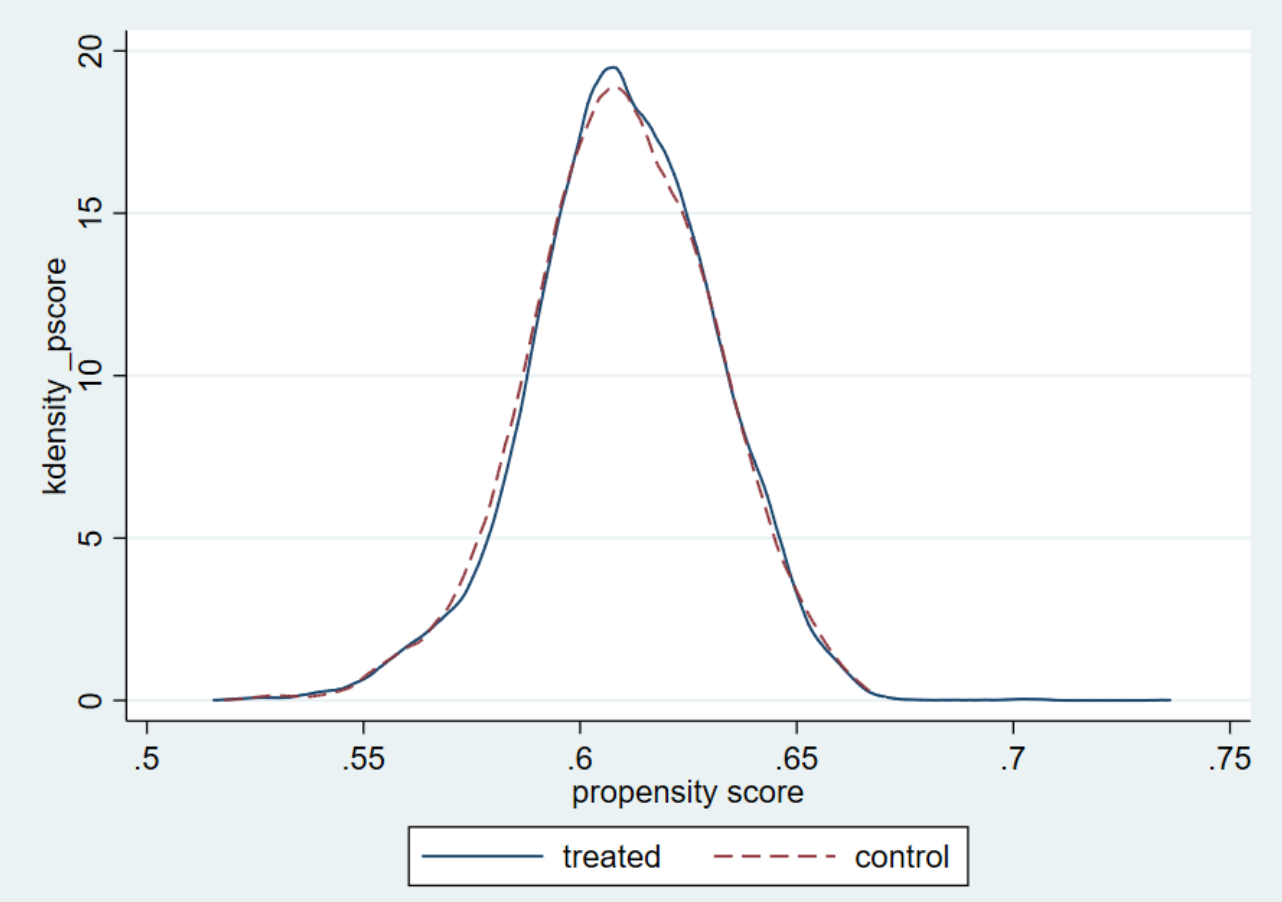

Source: Authors' elaboration based on ENCASEH and ENCEL data. 
Figure 3-c: Distribution of PS across Treatment and Comparison Groups - Female poor sample $0-18$

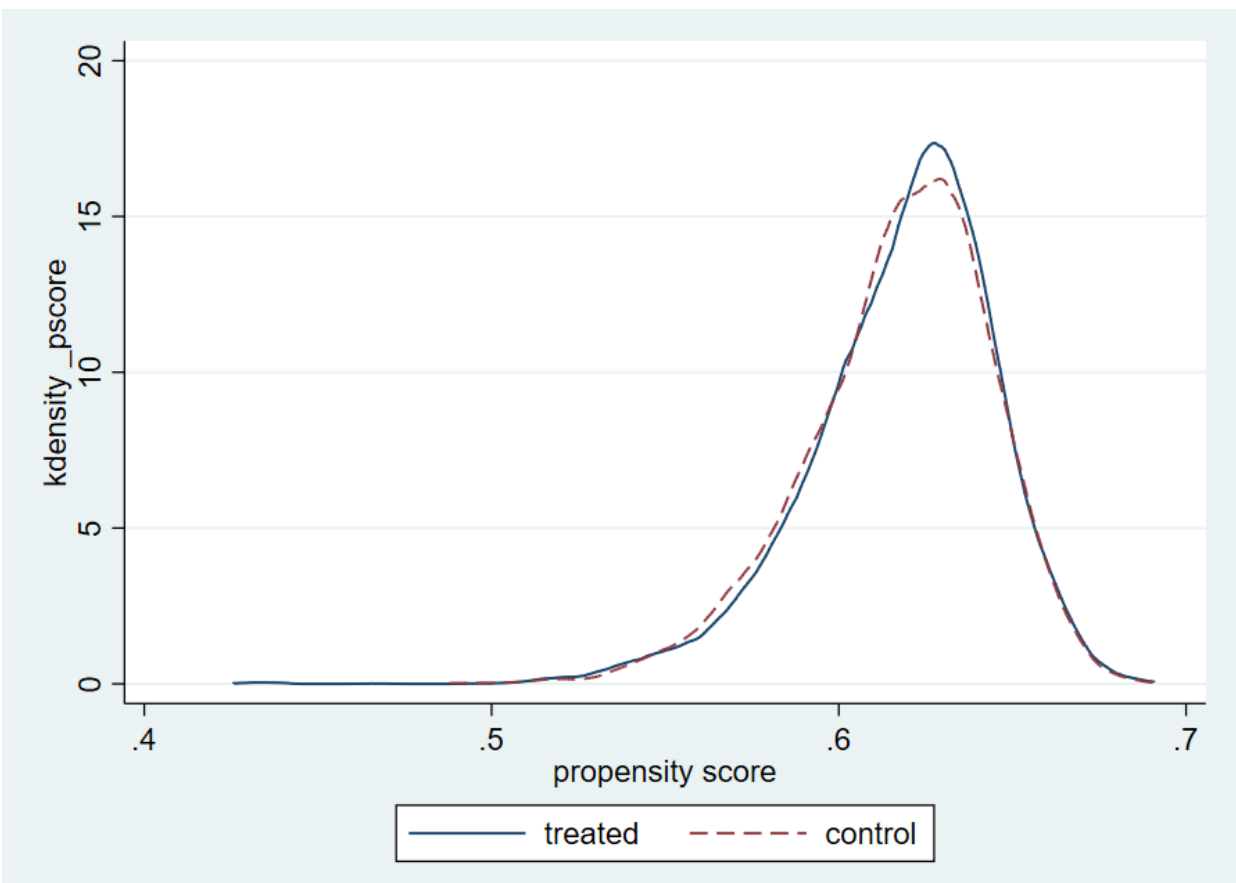

Source: Authors' elaboration based on ENCASEH and ENCEL data. 


\section{Appendix}

Appendix Table 1: MPI Framework

\begin{tabular}{|c|c|c|c|}
\hline "Dimensions & Indicator & Poverty Threshold & "Weight \\
\hline Education & Years of Schooling & $\begin{array}{l}\text { Deprived if no household member has } \\
\text { completed primary school }\end{array}$ & $1 / 3$ \\
\hline Health & Disabled & $\begin{array}{l}\text { Deprived if any household member is } \\
\text { disabled. }\end{array}$ & $1 / 3$ \\
\hline \multirow{4}{*}{ Living Standard } & Electricity & $\begin{array}{l}\text { Deprived if the household has no } \\
\text { electricity. }\end{array}$ & $1 / 12$ \\
\hline & Water & $\begin{array}{l}\text { Deprived if the household has no running } \\
\text { water. }\end{array}$ & $1 / 12$ \\
\hline & Flooring & $\begin{array}{l}\text { Deprived if the household has a dirt, sand } \\
\text { or dung floor. }\end{array}$ & $1 / 12$ \\
\hline & Asset Ownership & $\begin{array}{l}\text { Deprived if the household does not have } \\
\text { any of following items: radio, TV, } \\
\text { motorcycle, washing machine, } \\
\text { refrigerator, air conditioner or car. }\end{array}$ & $1 / 12$ \\
\hline
\end{tabular}

Source: Author's adaption from Alkire and Santos (2014), ENCASEH and ENCEL data. 
Appendix Table 2: A Panel Household Fixed-Effects Panel Estimation for MPI based on the panel 1997-2007

\begin{tabular}{lll}
\hline $\begin{array}{l}\text { Dependent Variable } \\
\text { Explanatory Variables }\end{array}$ & MPI & \\
\hline Head of household age & $-0.00111^{* * *}$ & $(0.0000283)$ \\
Whether the household head is male & -0.0000985 & $(0.00117)$ \\
Household Size & $-0.0144^{* * *}$ & $(0.000154)$ \\
Proportion of Young Children & $0.0889^{* *}$ & $(0.00463)$ \\
Whether the household head is working & $0.0107^{* * *}$ & $(0.000709)$ \\
Constant & $0.375^{* * *}$ & $(0.020179)$ \\
& & \\
sigma_u & 0.198 & \\
sigma_e & 0.0763 & \\
rho & 0.871 & \\
\hline No. of Observations & & \\
\hline
\end{tabular}

Notes: Robust standard errors in parentheses: * $\mathrm{p}<0.10 * * \mathrm{p}<0.05 * * * \mathrm{p}<0.01$.

Source: Authors' elaboration based on ENCASEH and ENCELs data 
Online Appendix

Online Appendix Table 1: Full PSM results: All poor sample 0-18

\begin{tabular}{|c|c|c|c|c|}
\hline Matching Algorithm & $\begin{array}{l}\text { Kernel } \\
\text { (1) }\end{array}$ & $\begin{array}{l}\text { Radius } \\
\text { (2) }\end{array}$ & $\begin{array}{l}\text { nearest } \\
\text { neighbour } \\
(3) \\
\end{array}$ & $\begin{array}{l}\text { local liner } \\
\text { regression } \\
(4)\end{array}$ \\
\hline \multicolumn{5}{|l|}{ Educational attainment } \\
\hline \multirow{2}{*}{ Education Years } & $0.227 * * *$ & $0.230 * * *$ & $0.237 * * *$ & $0.223 * * *$ \\
\hline & $(0.054)$ & $(0.054)$ & $(0.063)$ & $(0.071)$ \\
\hline \multirow{2}{*}{ Primary School Completion } & $0.012 * *$ & $0.012 * *$ & 0.01 & 0.013 \\
\hline & $(0.006)$ & $(0.006)$ & $(0.007)$ & $(0.008)$ \\
\hline \multirow{2}{*}{ Secondary School Completion } & $0.018 * * *$ & $0.018 * * *$ & $0.013 * *$ & $0.018 * *$ \\
\hline & $(0.006)$ & $(0.006)$ & $(0.007)$ & $(0.008)$ \\
\hline \multirow{2}{*}{ High School Completion } & $0.007 *$ & $0.007 * *$ & 0.002 & 0.007 \\
\hline & $(0.004)$ & $(0.004)$ & $(0.004)$ & $(0.005)$ \\
\hline \multirow{2}{*}{ Tertiary School Completion } & $0.003 *$ & $0.003 *$ & 0.003 & 0.003 \\
\hline & $(0.002)$ & $(0.002)$ & $(0.002)$ & $(0.002)$ \\
\hline \multicolumn{5}{|l|}{ Labour Market Performance } \\
\hline \multirow[t]{2}{*}{ Whether Working or not } & $0.015^{* * *}$ & $0.015^{* * *}$ & $0.012 *$ & $0.016 * *$ \\
\hline & $(0.006)$ & $(0.006)$ & $(0.007)$ & $(0.008)$ \\
\hline \multirow[t]{2}{*}{ Whether Working for a Salary } & $0.010^{*}$ & $0.009 *$ & 0.008 & 0.01 \\
\hline & $(0.005)$ & $(0.005)$ & $(0.006)$ & $(0.007)$ \\
\hline \multirow[t]{2}{*}{ Whether Working Voluntarily } & $0.006 * * *$ & $0.006^{* * *}$ & $0.007 * * *$ & $0.006 * *$ \\
\hline & $(0.002)$ & $(0.002)$ & $(0.003)$ & $(0.003)$ \\
\hline \multirow[t]{2}{*}{ Log Salary (weekly) } & $0.045^{* *}$ & $0.041 *$ & $0.055^{* *} *$ & $0.044 *$ \\
\hline & $(0.021)$ & $(0.021)$ & $(0.025)$ & $(0.027)$ \\
\hline \multirow[t]{2}{*}{ Log Salary (monthly) } & $0.054 * *$ & $0.052 *$ & $0.055^{*}$ & 0.047 \\
\hline & $(0.027)$ & $(0.027)$ & $(0.031)$ & $(0.035)$ \\
\hline
\end{tabular}

Figures in parentheses are robust standard errors; $* * * \mathrm{p}<0.01, * * \mathrm{p}<0.05, * \mathrm{p}<0.10$. In all the cases, we have controlled for the unobservable household characteristics.

Source: Authors' elaboration based on ENCASEH and ENCEL data 
Online Appendix Table 2: Full OLS Estimations: with Fixed Effect and Attrition Corrections

\begin{tabular}{|c|c|c|c|c|c|c|c|c|c|c|c|c|c|c|c|}
\hline \multirow{4}{*}{ Outcome Variable } & \multicolumn{12}{|c|}{ POOR (ITT) } & \multirow{2}{*}{\multicolumn{3}{|c|}{$\begin{array}{l}\text { NON-POOR (Spillover } \\
\text { effect) }\end{array}$}} \\
\hline & \multicolumn{3}{|c|}{$\begin{array}{l}\text { Total Sample (aged 0-18 in } \\
\text { 1997) }\end{array}$} & \multicolumn{3}{|c|}{$13-18$} & \multicolumn{3}{|c|}{$6-12$} & \multicolumn{3}{|c|}{$0-5$} & & & \\
\hline & Aggregate & Male & Female & Aggregate & Male & Female & Aggregate & Male & Female & Aggregate & Male & Female & Aggregate & Male & Female \\
\hline & (1) & (2) & (3) & (4) & (5) & (6) & (7) & (8) & (9) & (10) & (11) & (12) & (13) & (14) & (15) \\
\hline \multicolumn{16}{|l|}{ Educational attainment } \\
\hline \multirow[t]{2}{*}{ Education Years } & $0.389 * * *$ & $0.378^{*}$ & $0.408 * *$ & $0.454 * *$ & $0.395^{*}$ & $0.548 * *$ & $0.405 * *$ & $0.441^{*}$ & $0.375^{*}$ & $0.336^{*}$ & 0.310 & $0.398^{*}$ & 0.226 & 0.102 & $0.353^{*}$ \\
\hline & (0.184) & $(0.195)$ & $(0.187)$ & $(0.217)$ & $(0.228)$ & $(0.248)$ & (0.197) & $(0.228)$ & (0.195) & (0.191) & $(0.209)$ & $(0.210)$ & $(0.191)$ & $(0.205)$ & $(0.202)$ \\
\hline \multirow{2}{*}{$\begin{array}{l}\text { Secondary School } \\
\text { Completion }\end{array}$} & 0.0173 & 0.0136 & 0.0217 & 0.0233 & 0.0106 & $0.0379^{*}$ & 0.0256 & $0.0394 *$ & 0.0132 & 0.00120 & -0.0166 & 0.0211 & 0.00699 & 0.000487 & 0.0126 \\
\hline & $(0.0191)$ & $(\mathbf{0 . 0 2 0 5})$ & $(0.0196)$ & $(0.0192)$ & $(0.0199)$ & $(\mathbf{0 . 0 2 2 8})$ & $(0.0208)$ & $(\mathbf{0 . 0 2 3 8})$ & $(0.0223)$ & $(0.0233)$ & $(0.0262)$ & $(\mathbf{0 . 0 2 4 4 )}$ & $(0.0191)$ & $(0.0208)$ & $(0.0199)$ \\
\hline \multirow{2}{*}{$\begin{array}{l}\text { High School } \\
\text { Completion }\end{array}$} & 0.0175 & 0.0188 & 0.0170 & 0.00726 & 0.00436 & 0.0111 & 0.0191 & $0.0283^{*}$ & 0.0118 & 0.0226 & 0.0179 & 0.0305 & $0.0202^{*}$ & 0.0150 & $0.0256 * *$ \\
\hline & $(0.0118)$ & $(0.0129)$ & $(0.0121)$ & $(0.00771)$ & $(0.00870)$ & $(0.0104)$ & $(0.0123)$ & $(0.0147)$ & $(0.0119)$ & $(0.0180)$ & $(0.0197)$ & $(0.0208)$ & $(0.0107)$ & $(0.0122)$ & $(\mathbf{0 . 0 1 1 4})$ \\
\hline \multirow{2}{*}{$\begin{array}{l}\text { Tertiary School } \\
\text { Completion }\end{array}$} & 0.00489 & 0.00549 & 0.00475 & $0.00651^{* *}$ & $0.00928 * *$ & 0.00533 & 0.00670 & 0.00804 & 0.00616 & 0.000680 & 0.000860 & 0.00275 & 0.00111 & -0.000938 & 0.00317 \\
\hline & (0.00339) & $(0.00398)$ & $(0.00377)$ & $(\mathbf{0 . 0 0 3 1 1 )}$ & $(\mathbf{0 . 0 0 3 9 6 )}$ & $(0.00481)$ & $(0.00434)$ & $(0.00563)$ & $(0.00458)$ & $(0.00503)$ & $(0.00597)$ & $(0.00706)$ & $(0.00501)$ & $(0.00694)$ & $(0.00462)$ \\
\hline \multicolumn{16}{|l|}{ Labour Market } \\
\hline \multirow{2}{*}{$\begin{array}{c}\text { Performance } \\
\text { Whether Working or } \\
\text { not }\end{array}$} & 0.00358 & 0.000625 & 0.00386 & -0.00333 & -0.0186 & 0.0120 & 0.00520 & 0.0126 & -0.00759 & 0.00719 & -0.00350 & 0.0107 & -0.00835 & -0.0167 & 0.000214 \\
\hline & $(0.0192)$ & $(\mathbf{0 . 0 1 5 8 )}$ & $(\mathbf{0 . 0 2 4 8})$ & $(0.0214)$ & $(0.0208)$ & $(0.0274)$ & $(0.0199)$ & $(0.0170)$ & $(0.0270)$ & $(0.0219)$ & $(0.0193)$ & $(\mathbf{0 . 0 2 9 0 )}$ & $(0.0194)$ & $(0.0180)$ & $(0.0262)$ \\
\hline \multirow{2}{*}{$\begin{array}{c}\text { Whether Working for a } \\
\text { Salary }\end{array}$} & 0.00327 & -0.00220 & 0.00475 & 0.0106 & 0.0126 & 0.0105 & -0.00489 & -0.00562 & -0.0120 & 0.00841 & -0.00783 & 0.0188 & 0.000580 & -0.000251 & 0.00231 \\
\hline & $(\mathbf{0 . 0 1 4 5 )}$ & $(0.00923)$ & $(0.0215)$ & $(0.0169)$ & (0.0134) & $(0.0247)$ & $(0.0162)$ & $(0.0118)$ & $(0.0235)$ & $(0.0162)$ & $(0.0109)$ & $(0.0257)$ & $(0.0145)$ & (0.0108) & $(0.0224)$ \\
\hline \multirow[t]{2}{*}{$\begin{array}{l}\text { Whether Working } \\
\text { Voluntarily }\end{array}$} & 0.00183 & $\begin{array}{c}- \\
0.000403\end{array}$ & 0.00444 & -0.00630 & -0.0132 & 0.000149 & 0.00581 & 0.00593 & 0.00701 & 0.00281 & 0.000747 & 0.00507 & 0.00449 & -0.00183 & $0.0109 *$ \\
\hline & $(0.00482)$ & $(0.00550)$ & $(0.00590)$ & $(0.00619)$ & $(0.00879)$ & $(0.00755)$ & $(0.00566)$ & $(0.00638)$ & $(0.00705)$ & $(0.00515)$ & $(0.00714)$ & $(0.00649)$ & $(0.00440)$ & $(0.00568)$ & $(0.00600)$ \\
\hline \multirow[t]{2}{*}{ Log Salary (weekly) } & 0.0301 & 0.0110 & 0.0264 & 0.0318 & -0.0331 & 0.0290 & 0.00622 & -0.0264 & 0.00747 & 0.0435 & 0.0159 & 0.0390 & -0.0647 & 0.0757 & $-0.111 * *$ \\
\hline & $(\mathbf{0 . 0 3 6 1 )}$ & $(0.0614)$ & $(0.0428)$ & $(0.0614)$ & $(0.133)$ & $(0.0702)$ & $(0.0511)$ & $(0.0962)$ & $(0.0572)$ & $(0.0375)$ & $(0.0715)$ & $(0.0470)$ & $(0.0437)$ & $(0.0939)$ & $(0.0424)$ \\
\hline \multirow[t]{2}{*}{ Log Salary (monthly) } & 0.0600 & $0.0998 *$ & 0.0279 & 0.0537 & 0.0995 & 0.00303 & 0.0268 & 0.103 & -0.0365 & 0.0956 & 0.0627 & 0.107 & 0.0242 & 0.0182 & 0.0326 \\
\hline & $(0.0591)$ & $(0.0561)$ & $(0.0699)$ & $(0.0805)$ & $(0.0917)$ & $(0.105)$ & $(0.0626)$ & $(0.0660)$ & $(0.0769)$ & $(0.0661)$ & $(0.0775)$ & $(0.0795)$ & $(0.0885)$ & $(0.102)$ & $(0.0960)$ \\
\hline
\end{tabular}

Notes: Standard errors are clustered at the village level. Marginal effect (dy/dx) is reported for Probit models.; Robust standard errors in parentheses: $* \mathrm{p}<0.10 * * \mathrm{p}<0.05 * * *$

$\mathrm{p}<0.01$. Statistically significant cases are highlighted in bold.

Source: Authors' elaboration based on ENCASEH and ENCELs data. 
Online Appendix Table 3: Full Unconditional Quantile Estimations: with general Attrition Corrected

\begin{tabular}{|c|c|c|c|c|c|c|c|c|c|c|c|c|c|c|c|c|}
\hline & & \multicolumn{6}{|c|}{ POOR (ITT) } & \multicolumn{3}{|l|}{$6-12$} & \multicolumn{3}{|l|}{$0-5$} & \multicolumn{3}{|c|}{$\begin{array}{l}\text { NON-POOR (Spillover effect) } \\
\text { Total Sample (aged 0-18 in 1997) }\end{array}$} \\
\hline & & $\begin{array}{l}\text { Aggregate } \\
\text { (1) }\end{array}$ & $\begin{array}{l}\text { Male } \\
\text { (2) }\end{array}$ & $\begin{array}{l}\text { Female } \\
\text { (3) }\end{array}$ & $\begin{array}{l}\text { Aggregate } \\
\text { (4) }\end{array}$ & $\begin{array}{l}\text { Male } \\
(5)\end{array}$ & $\begin{array}{l}\text { Female } \\
(6)\end{array}$ & $\begin{array}{l}\text { Aggregate } \\
\text { (7) }\end{array}$ & $\begin{array}{l}\text { Male } \\
\text { (8) }\end{array}$ & $\begin{array}{l}\text { Female } \\
\text { (9) }\end{array}$ & $\begin{array}{l}\text { Aggregate } \\
\text { (10) }\end{array}$ & $\begin{array}{l}\text { Male } \\
(11)\end{array}$ & $\begin{array}{l}\text { Female } \\
(12)\end{array}$ & $\begin{array}{l}\text { Aggregate } \\
\text { (13) }\end{array}$ & $\begin{array}{l}\text { Male } \\
(14)\end{array}$ & $\begin{array}{l}\text { Female } \\
\text { (15) }\end{array}$ \\
\hline \multirow{12}{*}{ Education Years } & 10 & $0.0926^{* * * *}$ & $0.0710^{* *}$ & $0.815^{* * * *}$ & $0.717^{* * *}$ & 0.565 & $1.046 * * *$ & $0.0984 * * *$ & $0.167^{* * *}$ & $0.253^{* *}$ & 0.0901 & 0.102 & 0.119 & 0.0107 & 0.0958 & -0.0486 \\
\hline & & $(0.0186)$ & $(0.0281)$ & $(0.214)$ & $(0.261)$ & $(0.370)$ & $(0.403)$ & $(0.0316)$ & $(0.0545)$ & $(0.114)$ & $(0.0611)$ & $(0.0868)$ & $(0.106)$ & $(0.0573)$ & $(0.0919)$ & $(0.0855)$ \\
\hline & 25 & $0.0926 * * *$ & $0.0710^{* *}$ & $0.145^{* * *}$ & $0.189^{* * *}$ & $0.142 * *$ & $0.311 * * *$ & $0.0984^{* * *}$ & $0.167^{* * * *}$ & $0.132^{* * * *}$ & $0.915^{* * *}$ & 0.333 & $0.905 * * *$ & 0.0107 & 0.0958 & -0.0486 \\
\hline & & $(0.0186)$ & $(0.0281)$ & $(0.0320)$ & $(0.0455)$ & $(0.0713)$ & $(0.0766)$ & $(0.0316)$ & $(0.0545)$ & $(0.0489)$ & $(0.302)$ & $(0.208)$ & $(0.339)$ & $(0.0573)$ & $(0.0919)$ & $(0.0855)$ \\
\hline & 50 & $0.112 * * *$ & $0.126 * * *$ & $0.131^{* * *}$ & $0.189^{* * *}$ & $0.142^{* *}$ & $0.311 * * *$ & $0.147 * * *$ & $0.132 * * *$ & $0.132^{* * *}$ & $0.158^{* * *}$ & $0.141 *$ & $0.234 * * *$ & 0.0384 & -0.0558 & 0.122 \\
\hline & & $(0.0178)$ & $(0.0294)$ & $(0.0284)$ & $(0.0455)$ & $(0.0713)$ & $(0.0766)$ & $(0.0304)$ & $(0.0489)$ & $(0.0489)$ & $(0.0487)$ & $(0.0777)$ & $(0.0779)$ & $(0.0526)$ & $(0.0869)$ & $(0.0766)$ \\
\hline & 75 & $0.112 * * *$ & $0.126^{* * * *}$ & $0.131^{* * *}$ & $0.160^{* * *}$ & 0.150 & $0.232^{* *}$ & $0.147 * * *$ & $0.132 * * *$ & $0.167 * * *$ & $0.375^{* * *}$ & $0.400^{* * *}$ & $0.483 * * *$ & $0.468^{* * *}$ & $0.340^{* * *}$ & $0.965^{* * *}$ \\
\hline & & $(0.0178)$ & $(0.0294)$ & $(0.0284)$ & $(0.0601)$ & $(0.104)$ & $(0.0917)$ & $(0.0304)$ & $(0.0489)$ & $(0.0545)$ & $(0.0814)$ & $(0.122)$ & $(0.138)$ & $(0.104)$ & $(0.166)$ & $(0.197)$ \\
\hline & 90 & $0.241 * * *$ & $0.300^{* * * *}$ & $0.254^{* * * *}$ & $0.600 *$ & 0.150 & 0.405 & $0.301 * * *$ & $0.253^{* *}$ & $0.167 * * *$ & $0.375^{* * *}$ & $0.400 * * *$ & $0.483 * * *$ & $0.468 * * *$ & $0.340^{* *}$ & $0.683^{* * *}$ \\
\hline & & $(0.0370)$ & $(0.0594)$ & $(0.0604)$ & $(0.333)$ & $(0.104)$ & $(0.312)$ & $(0.0720)$ & $(0.114)$ & $(0.0545)$ & $(0.0814)$ & $(0.122)$ & $(0.138)$ & $(0.104)$ & $(0.166)$ & $(0.154)$ \\
\hline & FE & $0.412 * *$ & $0.400 * *$ & $0.431 * *$ & $0.476^{* *}$ & $0.410^{*}$ & $0.586^{* *}$ & $0.428^{* *}$ & $0.462 *$ & -12.05 & $0.363^{*}$ & 0.332 & $0.424 *$ & 0.235 & 0.121 & $0.352 *$ \\
\hline & & -0.189 & -0.202 & -0.192 & -0.221 & -0.23 & -0.254 & -0.203 & -0.237 & -8.467 & -0.198 & -0.215 & -0.216 & -0.189 & -0.204 & -0.201 \\
\hline \multirow{12}{*}{ Log Salary (weekly) } & 10 & $0.103 *$ & 0.0745 & 0.0711 & 0.125 & -0.0608 & 0.0223 & 0.0461 & 0.0175 & 0.0710 & 0.124 & 0.330 & 0.109 & -0.00328 & -0.0183 & $-0.127^{* * * *}$ \\
\hline & & $(0.0551)$ & $(0.137)$ & $(0.0498)$ & $(0.142)$ & $(0.485)$ & $(0.0917)$ & $(0.0777)$ & $(0.0623)$ & $(0.0444)$ & $(0.0831)$ & $(0.257)$ & $(0.0797)$ & $(0.0934)$ & $(0.192)$ & $(0.0452)$ \\
\hline & 25 & -0.0178 & 0.0140 & -0.0317 & -0.0721 & 0.00761 & $-0.0994 *$ & -0.0475 & $-0.0874 * *$ & 0.0510 & 0.0219 & -0.0179 & 0.0241 & -0.0326 & $0.220^{* *}$ & $-0.0758 * *$ \\
\hline & & $(0.0214)$ & $(0.0501)$ & $(0.0217)$ & $(0.0526)$ & $(0.148)$ & $(0.0580)$ & $(0.0355)$ & $(0.0390)$ & $(0.0414)$ & $(0.0387)$ & $(0.0818)$ & $(0.0390)$ & $(0.0355)$ & $(0.0958)$ & $(0.0367)$ \\
\hline & 50 & -0.00292 & -0.0576 & 0.00932 & 0.0408 & -0.0415 & 0.0705 & -0.0430 & -0.0595 & -0.0595 & 0.00966 & -0.104 & 0.0441 & -0.0415 & 0.106 & $-0.0838^{* *}$ \\
\hline & & $(0.0205)$ & $(0.0447)$ & $(0.0240)$ & $(0.0469)$ & $(0.108)$ & $(0.0528)$ & $(0.0348)$ & $(0.0400)$ & $(0.0400)$ & $(0.0331)$ & $(0.0699)$ & $(0.0378)$ & $(0.0335)$ & $(0.0746)$ & $(0.0383)$ \\
\hline & 75 & 0.00388 & -0.0155 & 0.0125 & 0.0474 & 0.0634 & 0.0356 & -0.00828 & 0.0510 & $-0.0874 * *$ & 0.0244 & -0.0158 & 0.0527 & -0.0137 & 0.0000888 & -0.0108 \\
\hline & & $(0.0195)$ & $(0.0338)$ & $(0.0277)$ & $(0.0437)$ & $(0.0644)$ & $(0.0572)$ & $(0.0363)$ & $(0.0414)$ & $(0.0390)$ & $(0.0323)$ & $(0.0546)$ & $(0.0402)$ & $(0.0410)$ & $(0.0665)$ & $(0.0463)$ \\
\hline & 90 & 0.00254 & -0.0255 & 0.0142 & 0.0611 & 0.0848 & 0.0318 & 0.0292 & 0.0710 & 0.0175 & -0.0372 & -0.0292 & -0.0363 & 0.000412 & 0.159 & -0.0542 \\
\hline & & $(0.0254)$ & $(0.0468)$ & $(0.0283)$ & $(0.0654)$ & $(0.0681)$ & $(0.0772)$ & $(0.0422)$ & $(0.0444)$ & $(0.0623)$ & $(0.0383)$ & $(0.0665)$ & $(0.0431)$ & $(0.0685)$ & $(0.142)$ & $(0.0737)$ \\
\hline & OLS & 0.0335 & 0.0168 & 0.029 & 0.0372 & -0.0281 & 0.033 & 0.00885 & -0.0094 & 0.31 & 0.0496 & 0.0171 & 0.0457 & -0.0607 & 0.0816 & $-0.109 * *$ \\
\hline & & -0.0363 & -0.0601 & -0.0431 & -0.0615 & -0.135 & -0.0741 & -0.0522 & -0.0995 & -2.323 & -0.038 & -0.0693 & -0.0486 & -0.0436 & -0.0952 & -0.0421 \\
\hline Log Salary (monthly) & 10 & $0.321 * * *$ & $0.435^{* * * *}$ & $0.241 * *$ & $0.281 *$ & 0.189 & 0.288 & $0.238^{* *}$ & 0.0353 & -0.0903 & $0.525^{* * *}$ & $0.473^{* *}$ & $0.441^{* * * *}$ & $0.236 *$ & 0.250 & 0.220 \\
\hline
\end{tabular}




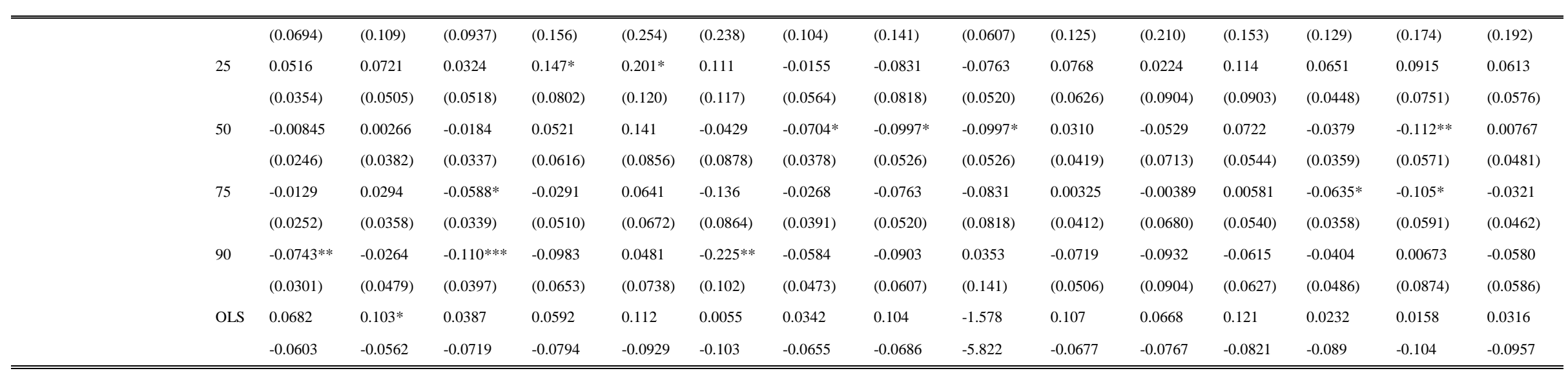

Notes: Figures in parentheses are robust standard errors; $* * * p<0.01, * * p<0.05, * p<0.10$;

Source: Authors' elaboration based on ENCASEH and ENCELs data. 
Online Appendix Table 3.1: Unrestricted and Restricted Attrition Probit Model: All poor sample 13-18

Dependent variable: Attrition dummy

\begin{tabular}{|c|c|c|c|c|c|c|}
\hline & $\begin{array}{l}\text { Aggregate } \\
\text { Unrestricted } \\
\text { attrition_2017 } \\
\text { (1) }\end{array}$ & $\begin{array}{l}\text { Restricted } \\
\text { attrition_2017 } \\
\text { (2) }\end{array}$ & $\begin{array}{l}\text { Male } \\
\text { Unrestricted } \\
\text { attrition_2017 } \\
\text { (3) }\end{array}$ & $\begin{array}{l}\text { Restricted } \\
\text { attrition_2017 } \\
\text { (4) }\end{array}$ & $\begin{array}{l}\text { Female } \\
\text { Unrestricted } \\
\text { attrition_2017 } \\
\text { (5) }\end{array}$ & $\begin{array}{l}\text { Restricted } \\
\text { attrition_2017 } \\
\text { (6) }\end{array}$ \\
\hline $\begin{array}{l}\text { Whether Treated in } \\
1997\end{array}$ & $\begin{array}{l}-0.0982 \\
(0.0986)\end{array}$ & $\begin{array}{l}-0.0901 \\
(0.101)\end{array}$ & $\begin{array}{l}-0.0682 \\
(0.158)\end{array}$ & $\begin{array}{l}-0.107 \\
(0.159)\end{array}$ & $\begin{array}{l}-0.146 \\
(0.134)\end{array}$ & $\begin{array}{l}-0.0991 \\
(0.134)\end{array}$ \\
\hline Age & $\begin{array}{l}-0.00380 \\
(0.00556)\end{array}$ & $\begin{array}{l}0.000891 \\
(0.00542)\end{array}$ & $\begin{array}{l}0.000512 \\
(0.00822)\end{array}$ & $\begin{array}{l}0.00415 \\
(0.00837)\end{array}$ & $\begin{array}{l}-0.00770 \\
(0.00701)\end{array}$ & $\begin{array}{l}-0.000724 \\
(0.00683)\end{array}$ \\
\hline Interactions & & & & & & \\
\hline Treated*Age & $\begin{array}{l}0.00761 \\
(0.00689)\end{array}$ & $\begin{array}{l}0.00836 \\
(0.00711)\end{array}$ & $\begin{array}{l}0.00634 \\
(0.0104)\end{array}$ & $\begin{array}{l}0.00619 \\
(0.0108)\end{array}$ & $\begin{array}{l}0.00902 \\
(0.00910)\end{array}$ & $\begin{array}{l}0.00925 \\
(0.00912)\end{array}$ \\
\hline Treated $*$ Sibling $0-5$ & $\begin{array}{l}0.0000805 \\
(0.0185)\end{array}$ & $\begin{array}{l}-0.0481^{* * *} \\
(0.0121)\end{array}$ & $\begin{array}{l}-0.0158 \\
(0.0217)\end{array}$ & $\begin{array}{l}-0.0175 \\
(0.0236)\end{array}$ & $\begin{array}{l}0.0157 \\
(0.0227)\end{array}$ & $\begin{array}{l}-0.0422 * * * \\
(0.0159)\end{array}$ \\
\hline Treated*Sibling 6-13 & $\begin{array}{l}-0.00422 \\
(0.0134)\end{array}$ & $\begin{array}{l}0.00479 \\
(0.0127)\end{array}$ & $\begin{array}{l}0.00810 \\
(0.0177)\end{array}$ & $\begin{array}{l}0.0141 \\
(0.0184)\end{array}$ & $\begin{array}{l}-0.0122 \\
(0.0158)\end{array}$ & $\begin{array}{l}-0.00489 \\
(0.0149)\end{array}$ \\
\hline $\begin{array}{l}\text { Treated*Sibling } 14- \\
15\end{array}$ & $\begin{array}{l}0.0120 \\
(0.0286)\end{array}$ & $\begin{array}{l}0.00550 \\
(0.0295)\end{array}$ & $\begin{array}{l}0.00696 \\
(0.0373)\end{array}$ & $\begin{array}{l}0.00964 \\
(0.0391)\end{array}$ & $\begin{array}{l}0.0185 \\
(0.0354)\end{array}$ & $\begin{array}{l}0.0104 \\
(0.0350)\end{array}$ \\
\hline Number of siblings & & & & & & \\
\hline Aged $0-5$ & $\begin{array}{l}-0.0427 * * * \\
(0.0154)\end{array}$ & & $\begin{array}{l}-0.0280 \\
(0.0178)\end{array}$ & $\begin{array}{l}-0.0421^{* *} \\
(0.0189)\end{array}$ & $\begin{array}{l}-0.0580^{* * * *} \\
(0.0183)\end{array}$ & \\
\hline Aged $6-13$ & $\begin{array}{l}-0.0148 \\
(0.0127)\end{array}$ & $\begin{array}{l}-0.0346^{* * * *} \\
(0.0114)\end{array}$ & $\begin{array}{l}-0.0243 \\
(0.0161)\end{array}$ & $\begin{array}{l}-0.0513^{* * *} \\
(0.0150)\end{array}$ & $\begin{array}{l}-0.00653 \\
(0.0148)\end{array}$ & $\begin{array}{l}-0.0238^{*} \\
(0.0140)\end{array}$ \\
\hline Aged $14-15$ & $\begin{array}{l}-0.00455 \\
(0.0246)\end{array}$ & $\begin{array}{l}-0.00727 \\
(0.0249)\end{array}$ & $\begin{array}{l}-0.00158 \\
(0.0312)\end{array}$ & $\begin{array}{l}-0.0191 \\
(0.0323)\end{array}$ & $\begin{array}{l}-0.00890 \\
(0.0308)\end{array}$ & $\begin{array}{l}-0.0103 \\
(0.0306)\end{array}$ \\
\hline Province: Compared & ith Guerrero & & & & & \\
\hline Hidalgo & $\begin{array}{l}0.0420 \\
(0.0504)\end{array}$ & $\begin{array}{l}-0.0565^{*} \\
(0.0321)\end{array}$ & $\begin{array}{l}0.0779 * \\
(0.0464)\end{array}$ & & $\begin{array}{l}0.0119 \\
(0.0603)\end{array}$ & \\
\hline Michoacán & $\begin{array}{l}0.122^{* *} \\
(0.0576)\end{array}$ & & $\begin{array}{l}0.159 * * * \\
(0.0554)\end{array}$ & & $\begin{array}{l}0.0966 \\
(0.0653)\end{array}$ & $\begin{array}{l}-0.0160 \\
(0.0483)\end{array}$ \\
\hline Puebla & $\begin{array}{l}0.00261 \\
(0.0527)\end{array}$ & $\begin{array}{l}-0.0957^{* *} \\
(0.0393)\end{array}$ & $\begin{array}{l}0.0581 \\
(0.0525)\end{array}$ & $\begin{array}{l}-0.0756^{*} \\
(0.0391)\end{array}$ & $\begin{array}{l}-0.0427 \\
(0.0560)\end{array}$ & \\
\hline Querétaro & $\begin{array}{l}0.126^{*} \\
(0.0699)\end{array}$ & & $\begin{array}{l}0.168^{* *} \\
(0.0683)\end{array}$ & & $\begin{array}{l}0.0916 \\
(0.0802)\end{array}$ & $\begin{array}{l}0.0632 \\
(0.0792)\end{array}$ \\
\hline San Luis Potosí & $\begin{array}{l}0.0968 * \\
(0.0536)\end{array}$ & & $\begin{array}{l}0.172 * * * \\
(0.0506)\end{array}$ & & $\begin{array}{l}0.0329 \\
(0.0630)\end{array}$ & $\begin{array}{l}-0.0256 \\
(0.0453)\end{array}$ \\
\hline Veracruz & $\begin{array}{l}0.155^{* * * *} \\
(0.0480)\end{array}$ & & $\begin{array}{l}0.209^{* * * *} \\
(0.0457)\end{array}$ & & $\begin{array}{l}0.111 * * \\
(0.0553)\end{array}$ & \\
\hline Household Size & $\begin{array}{l}-0.00814 \\
(0.00747)\end{array}$ & $\begin{array}{l}-0.0346^{* * * *} \\
(0.00488)\end{array}$ & $\begin{array}{l}-0.00478 \\
(0.00858)\end{array}$ & $\begin{array}{l}-0.0205^{* * * *} \\
(0.00591)\end{array}$ & $\begin{array}{l}-0.0111 \\
(0.0109)\end{array}$ & $\begin{array}{l}-0.0416^{* * *} \\
(0.00661)\end{array}$ \\
\hline Share of Children & $\begin{array}{l}0.809 * * * \\
(0.263)\end{array}$ & & $\begin{array}{l}0.726^{* * *} \\
(0.300)\end{array}$ & & $\begin{array}{l}0.935^{* * *} \\
(0.408)\end{array}$ & \\
\hline Whether Owns TV & $\begin{array}{l}-0.279 * * * \\
(0.0239)\end{array}$ & & $\begin{array}{l}-0.259 * * * \\
(0.0268)\end{array}$ & & $\begin{array}{l}-0.296 * * * \\
(0.0277)\end{array}$ & \\
\hline Whether Owns Car & $\begin{array}{l}-0.0786^{* * *} \\
(0.0263)\end{array}$ & & $\begin{array}{l}-0.0562 * \\
(0.0301)\end{array}$ & & $\begin{array}{l}-0.102 * * * \\
(0.0321)\end{array}$ & \\
\hline $\begin{array}{l}\text { Whether Owns } \\
\text { House }\end{array}$ & $-0.290 * * *$ & & $-0.290 * * *$ & & $-0.283 * * *$ & \\
\hline
\end{tabular}




\begin{tabular}{lllllll} 
& $(0.0895)$ & & $(0.109)$ & & $(0.103)$ & \\
Whether with & -0.000613 & 0.0132 & -0.0184 & -0.0151 & 0.0138 & 0.0297 \\
disabled member & $(0.0315)$ & $(0.0340)$ & $(0.0390)$ & $(0.0403)$ & $(0.0360)$ & $(0.0385)$ \\
& & & $0.000455^{* * *}$ & & $0.000269^{*}$ & \\
Poverty Rate in 1997 & $0.000354^{* * *}$ & & $(0.000124)$ & & $(0.000142)$ & \\
& $(0.000114)$ & & 3437 & 3437 & 3658 & 3658 \\
\hline $\mathrm{N}$ & 7095 & 7095 & & & & \\
\hline \hline
\end{tabular}

Notes: Standard errors are clustered at the village level. Robust standard errors in parentheses: * $\mathrm{p}<0.10 * * \mathrm{p}<0.05 * * * \mathrm{p}<0.01$. Source: Authors' elaboration based on ENCASEH and ENCEL data.

Online Appendix Table 3.2: Unrestricted and Restricted Attrition Probit Model: All poor sample 6-12

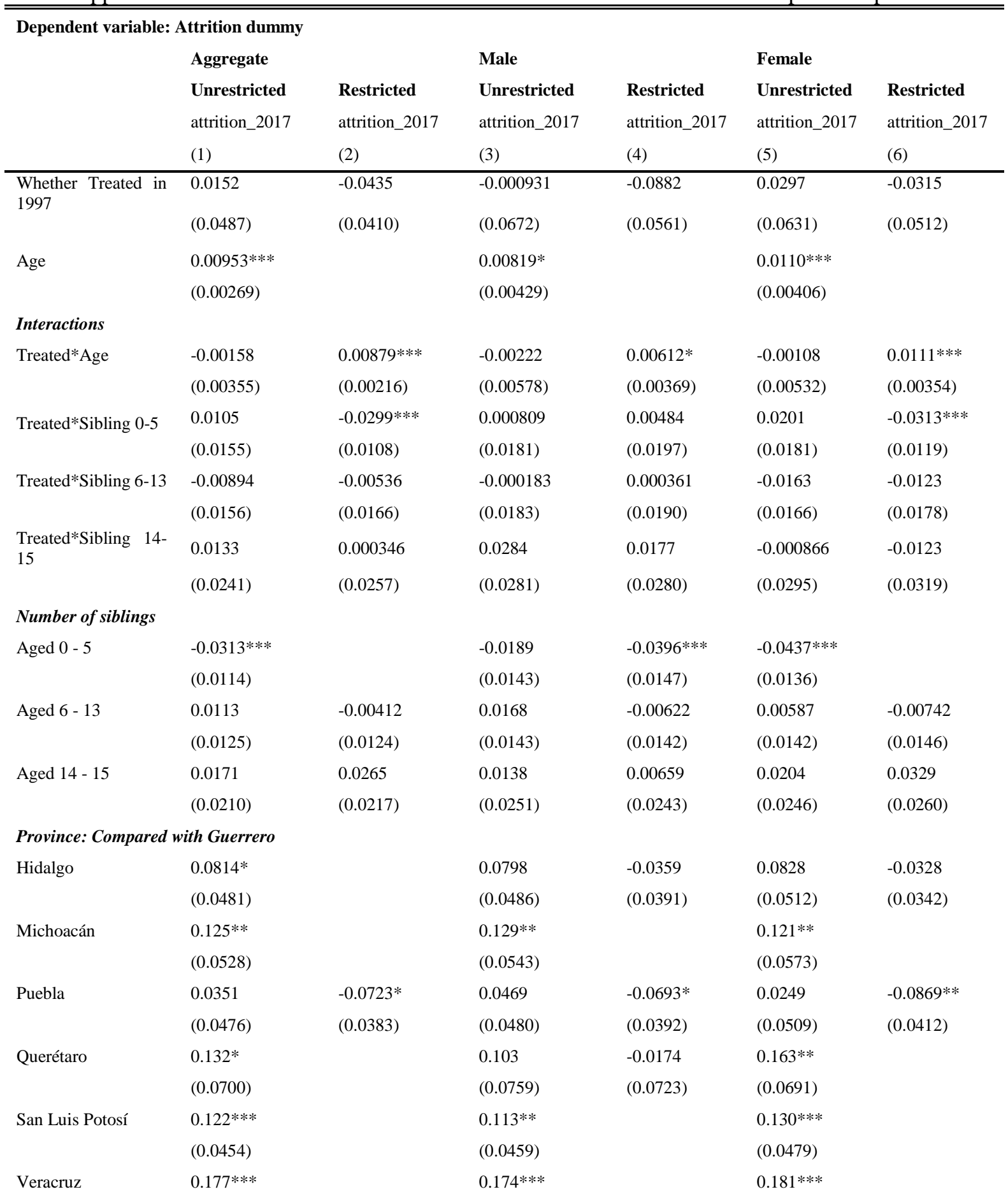




\begin{tabular}{|c|c|c|c|c|c|c|}
\hline & $(0.0447)$ & & $(0.0450)$ & & $(0.0482)$ & \\
\hline \multirow[t]{2}{*}{ Household Size } & -0.00789 & $-0.0335 * * *$ & -0.00938 & $-0.0262 * * *$ & -0.00704 & $-0.0339 * * *$ \\
\hline & $(0.00777)$ & $(0.00502)$ & $(0.00936)$ & $(0.00568)$ & $(0.00888)$ & $(0.00565)$ \\
\hline \multirow[t]{2}{*}{ Share of Children } & $0.984 * * *$ & & $1.000 * *$ & & $0.939 * *$ & \\
\hline & $(0.320)$ & & $(0.399)$ & & $(0.401)$ & \\
\hline \multirow[t]{2}{*}{ Whether Owns TV } & $-0.313^{* * *}$ & & $-0.319^{* * *}$ & & $-0.309 * * *$ & \\
\hline & $(0.0257)$ & & $(0.0269)$ & & $(0.0311)$ & \\
\hline \multirow[t]{2}{*}{ Whether Owns Car } & $-0.110^{* * *}$ & & $-0.105^{* * *}$ & & $-0.117 * * *$ & \\
\hline & $(0.0188)$ & & $(0.0229)$ & & $(0.0218)$ & \\
\hline \multirow[t]{2}{*}{$\begin{array}{l}\text { Whether } \\
\text { House }\end{array}$} & $-0.292 * * *$ & & $-0.378 * * *$ & & $-0.229 * * *$ & \\
\hline & $(0.0692)$ & & $(0.0983)$ & & $(0.0826)$ & \\
\hline \multirow[t]{2}{*}{$\begin{array}{l}\text { Whether with } \\
\text { disabled member }\end{array}$} & -0.00180 & 0.00406 & 0.00619 & 0.00230 & -0.00660 & 0.00204 \\
\hline & $(0.0272)$ & $(0.0276)$ & $(0.0363)$ & $(0.0363)$ & $(0.0286)$ & $(0.0303)$ \\
\hline \multirow[t]{2}{*}{ Poverty Rate in 1997} & $0.000289 * * *$ & & $0.000346 * * *$ & & $0.000241 *$ & \\
\hline & $(0.000110)$ & & $(0.000115)$ & & $(0.000128)$ & \\
\hline $\mathrm{N}$ & 12642 & 12642 & 6184 & 6184 & 6458 & 6458 \\
\hline
\end{tabular}

Notes: Standard errors are clustered at the village level. Robust standard errors in parentheses: $* \mathrm{p}<0.10 * * \mathrm{p}<0.05 * * * \mathrm{p}<0.01$.

Source: Authors' elaboration based on ENCASEH and ENCEL data.

Online Appendix Table 3.3: Unrestricted and Restricted Attrition Probit Model: All poor sample 0-5

\begin{tabular}{|c|c|c|c|c|c|c|}
\hline \multicolumn{7}{|c|}{ Dependent variable: Attrition dummy } \\
\hline & $\begin{array}{l}\text { Aggregate } \\
\text { Unrestricted } \\
\text { attrition_2017 } \\
\text { (1) }\end{array}$ & $\begin{array}{l}\text { Restricted } \\
\text { attrition_2017 } \\
\text { (2) }\end{array}$ & $\begin{array}{l}\text { Male } \\
\text { Unrestricted } \\
\text { attrition_2017 } \\
\text { (3) }\end{array}$ & $\begin{array}{l}\text { Restricted } \\
\text { attrition_2017 } \\
\text { (4) }\end{array}$ & $\begin{array}{l}\text { Female } \\
\text { Unrestricted } \\
\text { attrition_2017 } \\
\text { (5) }\end{array}$ & $\begin{array}{l}\text { Restricted } \\
\text { attrition_2017 } \\
\text { (6) }\end{array}$ \\
\hline $\begin{array}{l}\text { Whether Treated in } \\
1997\end{array}$ & $\begin{array}{l}0.0498 \\
(0.0370)\end{array}$ & $\begin{array}{l}0.0112 \\
(0.0347)\end{array}$ & $\begin{array}{l}0.0832 * \\
(0.0446)\end{array}$ & $\begin{array}{l}0.0221 \\
(0.0424)\end{array}$ & $\begin{array}{l}0.0179 \\
(0.0446)\end{array}$ & $\begin{array}{l}0.0215 \\
(0.0439)\end{array}$ \\
\hline Age & $\begin{array}{l}-0.00606 \\
(0.00388)\end{array}$ & $\begin{array}{l}-0.00949 * * \\
(0.00434)\end{array}$ & $\begin{array}{l}-0.00395 \\
(0.00593)\end{array}$ & $\begin{array}{l}-0.00731 \\
(0.00615)\end{array}$ & $\begin{array}{l}-0.00819 \\
(0.00548)\end{array}$ & $\begin{array}{l}-0.0109 * \\
(0.00558)\end{array}$ \\
\hline \multicolumn{7}{|l|}{ Interactions } \\
\hline Treated*Age & $\begin{array}{l}0.00198 \\
(0.00523)\end{array}$ & $\begin{array}{l}0.00115 \\
(0.00578)\end{array}$ & $\begin{array}{l}0.00215 \\
(0.00763)\end{array}$ & $\begin{array}{l}0.00321 \\
(0.00831)\end{array}$ & $\begin{array}{l}0.00209 \\
(0.00668)\end{array}$ & $\begin{array}{l}0.000699 \\
(0.00699)\end{array}$ \\
\hline Treated*Sibling $0-5$ & $\begin{array}{l}-0.000737 \\
(0.0201)\end{array}$ & $\begin{array}{l}-0.00578 \\
(0.0210)\end{array}$ & $\begin{array}{l}-0.00157 \\
(0.0228)\end{array}$ & $\begin{array}{l}-0.00718 \\
(0.0239)\end{array}$ & $\begin{array}{l}-0.00109 \\
(0.0240)\end{array}$ & $\begin{array}{l}-0.00629 \\
(0.0256)\end{array}$ \\
\hline Treated*Sibling 6-13 & $\begin{array}{l}-0.0221^{* *} \\
(0.0105)\end{array}$ & & $\begin{array}{l}-0.0336^{* *} \\
(0.0133)\end{array}$ & & $\begin{array}{l}-0.0103 \\
(0.0127)\end{array}$ & $\begin{array}{l}-0.0138 \\
(0.0137)\end{array}$ \\
\hline $\begin{array}{l}\text { Treated*Sibling } 14- \\
15\end{array}$ & $\begin{array}{l}0.00837 \\
0.00198\end{array}$ & $\begin{array}{l}-0.00996 \\
0.00115\end{array}$ & $\begin{array}{l}0.0242 \\
0.00215\end{array}$ & $\begin{array}{l}0.00277 \\
0.00321\end{array}$ & $\begin{array}{l}-0.00881 \\
0.00209\end{array}$ & $\begin{array}{l}-0.0117 \\
0.000699\end{array}$ \\
\hline Number of siblings & & & & & & \\
\hline Aged $0-5$ & $\begin{array}{l}-0.0136 \\
(0.0163)\end{array}$ & $\begin{array}{l}-0.0230 \\
(0.0153)\end{array}$ & $\begin{array}{l}-0.0146 \\
(0.0197)\end{array}$ & $\begin{array}{l}-0.0348 * \\
(0.0202)\end{array}$ & $\begin{array}{l}-0.0113 \\
(0.0187)\end{array}$ & $\begin{array}{l}-0.0306 \\
(0.0189)\end{array}$ \\
\hline Aged $6-13$ & $\begin{array}{l}0.0205^{*} \\
(0.0110)\end{array}$ & & $\begin{array}{l}0.0199 \\
(0.0126)\end{array}$ & $\begin{array}{l}-0.0285 * * * \\
(0.00880)\end{array}$ & $\begin{array}{l}0.0210 \\
(0.0130)\end{array}$ & $\begin{array}{l}-0.00462 \\
(0.0132)\end{array}$ \\
\hline Aged $14-15$ & $\begin{array}{l}0.0166 \\
(0.0239)\end{array}$ & $\begin{array}{l}0.0195 \\
(0.0240)\end{array}$ & $\begin{array}{l}0.0142 \\
(0.0256)\end{array}$ & $\begin{array}{l}0.0111 \\
(0.0273)\end{array}$ & $\begin{array}{l}0.0194 \\
(0.0298)\end{array}$ & $\begin{array}{l}0.00630 \\
(0.0298)\end{array}$ \\
\hline Province: Compared $n$ & ith Guerrero & & & & & \\
\hline Hidalgo & 0.0657 & -0.0317 & 0.0750 & -0.0347 & 0.0558 & -0.0389 \\
\hline
\end{tabular}




\begin{tabular}{|c|c|c|c|c|c|c|}
\hline & $(0.0510)$ & $(0.0394)$ & $(0.0515)$ & $(0.0397)$ & $(0.0568)$ & $(0.0449)$ \\
\hline \multirow[t]{2}{*}{ Michoacán } & $0.122^{* *}$ & & $0.123^{* *}$ & & $0.124 * *$ & \\
\hline & $(0.0541)$ & & $(0.0594)$ & & $(0.0577)$ & \\
\hline \multirow[t]{2}{*}{ Puebla } & 0.0268 & -0.0633 & 0.0567 & -0.0462 & -0.00322 & $-0.0899 * *$ \\
\hline & $(0.0542)$ & $(0.0402)$ & $(0.0562)$ & $(0.0427)$ & $(0.0586)$ & $(0.0436)$ \\
\hline \multirow[t]{2}{*}{ Querétaro } & $0.169^{* * *}$ & & $0.173^{* *}$ & & $0.166^{* *}$ & \\
\hline & $(0.0651)$ & & $(0.0716)$ & & $(0.0688)$ & \\
\hline \multirow[t]{2}{*}{ San Luis Potosí } & $0.0894 *$ & & 0.0847 & -0.0525 & $0.0927^{*}$ & \\
\hline & $(0.0475)$ & & $(0.0530)$ & $(0.0412)$ & $(0.0499)$ & \\
\hline \multirow[t]{2}{*}{ Veracruz } & $0.156^{* * *}$ & & $0.155^{* * *}$ & & $0.158 * * *$ & \\
\hline & $(0.0458)$ & & $(0.0490)$ & & $(0.0499)$ & \\
\hline \multirow[t]{2}{*}{ Household Size } & 0.00486 & $-0.0292 * * *$ & 0.00893 & $-0.0178 * * *$ & 0.0000242 & $-0.0213 * * *$ \\
\hline & $(0.00798)$ & $(0.00393)$ & $(0.00917)$ & $(0.00605)$ & $(0.00973)$ & $(0.00801)$ \\
\hline \multirow[t]{2}{*}{ Share of Children } & $1.396 * * *$ & & $1.546 * * *$ & & $1.240 * * *$ & \\
\hline & $(0.304)$ & & $(0.328)$ & & $(0.374)$ & \\
\hline \multirow[t]{2}{*}{ Whether Owns TV } & $-0.334 * * *$ & & $-0.318 * * *$ & & $-0.351 * * *$ & \\
\hline & $(0.0259)$ & & $(0.0314)$ & & $(0.0258)$ & \\
\hline \multirow[t]{2}{*}{ Whether Owns Car } & $-0.119 * * *$ & & $-0.103^{* * *}$ & & $-0.136^{* * *}$ & \\
\hline & $(0.0210)$ & & $(0.0283)$ & & $(0.0237)$ & \\
\hline \multirow[t]{2}{*}{$\begin{array}{l}\text { Whether } \\
\text { House }\end{array}$} & $-0.422 * * *$ & & $-0.456^{* * *}$ & & $-0.405^{* * *}$ & \\
\hline & $(0.0548)$ & & $(0.0768)$ & & $(0.0663)$ & \\
\hline \multirow[t]{2}{*}{$\begin{array}{l}\text { Whether with } \\
\text { disabled member }\end{array}$} & -0.0262 & -0.0235 & $-0.0627^{*}$ & & 0.0157 & 0.0108 \\
\hline & $(0.0282)$ & $(0.0334)$ & $(0.0352)$ & & $(0.0348)$ & $(0.0418)$ \\
\hline \multirow[t]{2}{*}{ Poverty Rate in 1997} & $0.000346^{* * *}$ & & $0.000355^{* *}$ & & $0.000334 * *$ & \\
\hline & $(0.000127)$ & & $(0.000139)$ & & $(0.000143)$ & \\
\hline $\mathrm{N}$ & 10037 & 10037 & 4968 & 4968 & 5069 & 5069 \\
\hline
\end{tabular}

Notes: Standard errors are clustered at the village level. Robust standard errors in parentheses: $* \mathrm{p}<0.10 * * \mathrm{p}<0.05 * * * \mathrm{p}<0.01$. Source: Authors' elaboration based on ENCASEH and ENCEL data.

Appendix Table 3.4: Unrestricted and Restricted Attrition Probit Model: All poor sample 3-5

Dependent variable: Attrition dummy

\section{Aggregate}

Unrestricted

attrition_2017

(1)$$
\begin{aligned}
& \text { Wh } \\
& 1997 \\
& \text { Ag }
\end{aligned}
$$

Age

\section{Interactions}

Treated*Age

Treated*Sibling 0-5

(0.0208)

Treated*Sibling 6-13 $\quad-0.0221^{*}$

$(0.0122)$ Treated*Sibling $14-\quad 0.00489$
15

0.0205

(0.0636)

$-0.0173$

(0.0107)

0.00789

(0.0140)

0.0149

(0.0158)

0.00000871

(0.0220)

$-0.0118$

Male

Unrestricted

attrition_2017

(3)

0.0759

(0.0918)

$-0.0110$

$(0.0171)$

$-0.000681$

(0.0205)

$-0.00554$

(0.0262)

$-0.0199$

(0.0171)

0.0133 


\begin{tabular}{|c|c|c|c|c|c|c|}
\hline & $(0.0283)$ & $(0.0321)$ & $(0.0406)$ & $(0.0432)$ & $(0.0352)$ & $(0.0377)$ \\
\hline \multicolumn{7}{|l|}{ Number of siblings } \\
\hline \multirow[t]{2}{*}{ Aged 0 - 5} & -0.0139 & $-0.0339 *$ & -0.00373 & -0.0238 & -0.0200 & -0.0345 \\
\hline & $(0.0172)$ & $(0.0181)$ & $(0.0237)$ & $(0.0267)$ & $(0.0207)$ & $(0.0215)$ \\
\hline \multirow[t]{2}{*}{ Aged $6-13$} & 0.0177 & $-0.0223 * *$ & 0.0133 & -0.0207 & 0.0209 & 0.00659 \\
\hline & $(0.0130)$ & $(0.00927)$ & $(0.0162)$ & $(0.0156)$ & $(0.0168)$ & $(0.0185)$ \\
\hline \multirow[t]{2}{*}{ Aged $14-15$} & 0.0267 & 0.0198 & 0.0465 & 0.0310 & 0.00922 & -0.000283 \\
\hline & $(0.0245)$ & $(0.0256)$ & $(0.0322)$ & $(0.0325)$ & $(0.0323)$ & $(0.0333)$ \\
\hline \multicolumn{7}{|c|}{ Province: Compared with Guerrero } \\
\hline \multirow[t]{2}{*}{ Hidalgo } & 0.0483 & -0.0467 & 0.0363 & $-0.0812 *$ & 0.0602 & -0.0376 \\
\hline & $(0.0532)$ & $(0.0445)$ & $(0.0556)$ & $(0.0479)$ & $(0.0587)$ & $(0.0521)$ \\
\hline \multirow[t]{2}{*}{ Michoacán } & $0.102^{*}$ & & 0.0978 & $-0.109 * *$ & $0.107 *$ & \\
\hline & $(0.0566)$ & & $(0.0605)$ & $(0.0489)$ & $(0.0637)$ & \\
\hline \multirow[t]{2}{*}{ Puebla } & 0.0231 & -0.0673 & 0.0616 & -0.0525 & -0.0164 & $-0.111 * *$ \\
\hline & $(0.0548)$ & $(0.0451)$ & $(0.0573)$ & $(0.0471)$ & $(0.0611)$ & $(0.0519)$ \\
\hline \multirow[t]{2}{*}{ Querétaro } & $0.142 * *$ & & 0.121 & -0.00310 & $0.167 * *$ & \\
\hline & $(0.0703)$ & & $(0.0799)$ & $(0.0756)$ & $(0.0768)$ & \\
\hline \multirow[t]{2}{*}{ San Luis Potosí } & 0.0807 & -0.0495 & 0.0884 & -0.0668 & 0.0723 & -0.0559 \\
\hline & $(0.0491)$ & $(0.0419)$ & $(0.0567)$ & $(0.0501)$ & $(0.0510)$ & $(0.0446)$ \\
\hline \multirow[t]{2}{*}{ Veracruz } & $0.146 * * *$ & & $0.152 * * *$ & & $0.142 * * *$ & \\
\hline & $(0.0451)$ & & $(0.0500)$ & & $(0.0499)$ & \\
\hline \multirow[t]{2}{*}{ Household Size } & 0.00269 & $-0.0213 * * *$ & 0.00657 & $-0.0196^{* * *}$ & -0.00490 & $-0.0264 * * *$ \\
\hline & $(0.00934)$ & $(0.00593)$ & $(0.0108)$ & $(0.00696)$ & $(0.0125)$ & $(0.00938)$ \\
\hline \multirow[t]{2}{*}{ Share of Children } & $1.454 * * *$ & & $1.692 * * *$ & & $1.084 * *$ & \\
\hline & $(0.406)$ & & $(0.437)$ & & $(0.515)$ & \\
\hline \multirow[t]{2}{*}{ Whether Owns TV } & $-0.343 * * *$ & & $-0.313 * * *$ & & $-0.369 * * *$ & \\
\hline & $(0.0301)$ & & $(0.0374)$ & & $(0.0326)$ & \\
\hline \multirow[t]{2}{*}{ Whether Owns Car } & $-0.130 * * *$ & & $-0.120 * * *$ & & $-0.140 * * *$ & \\
\hline & $(0.0241)$ & & $(0.0348)$ & & $(0.0284)$ & \\
\hline \multirow[t]{2}{*}{$\begin{array}{l}\text { Whether } \\
\text { House }\end{array}$} & $-0.402 * * *$ & & $-0.426 * * *$ & & $-0.386^{* * *}$ & \\
\hline & $(0.0628)$ & & $(0.0877)$ & & $(0.0817)$ & \\
\hline \multirow[t]{2}{*}{$\begin{array}{l}\text { Whether with } \\
\text { disabled member }\end{array}$} & -0.00481 & -0.0100 & -0.0681 & -0.0731 & 0.0558 & 0.0530 \\
\hline & $(0.0335)$ & $(0.0378)$ & $(0.0460)$ & $(0.0500)$ & $(0.0451)$ & $(0.0509)$ \\
\hline \multirow[t]{2}{*}{ Poverty Rate in 1997} & $0.000283 * *$ & & $0.000307 * *$ & & 0.000253 & -0.0000298 \\
\hline & $(0.000135)$ & & $(0.000145)$ & & $(0.000163)$ & $(0.000161)$ \\
\hline $\mathrm{N}$ & 5537 & 5537 & 2742 & 2742 & 2795 & 2795 \\
\hline
\end{tabular}

Notes: Standard errors are clustered at the village level. Robust standard errors in parentheses: * $\mathrm{p}<0.10 * * \mathrm{p}<0.05 * * * \mathrm{p}<0.01$. Source: Authors' elaboration based on ENCASEH and ENCEL data.

Online Appendix Table 3.5: Unrestricted and Restricted Attrition Probit Model: All poor sample 0-2

\begin{tabular}{lllllll}
\hline \hline Dependent variable: Attrition dummy & & & & & \\
& $\begin{array}{l}\text { Mggregate } \\
\text { Unrestricted } \\
\text { attrition_2017 }\end{array}$ & $\begin{array}{l}\text { Restricted } \\
\text { attrition_2017 } \\
(1)\end{array}$ & $\begin{array}{l}\text { Unrestricted } \\
\text { attrition_2017 } \\
(2)\end{array}$ & $\begin{array}{l}\text { Restricted } \\
\text { attrition_2017 }\end{array}$ & $\begin{array}{l}\text { Unrestricted } \\
\text { attrition_2017 }\end{array}$ & $\begin{array}{l}\text { Restricted } \\
\text { attrition_2017 }\end{array}$ \\
& $(1)$ & $(4)$ & $(5)$ & $(6)$ \\
\hline $\begin{array}{l}\text { Whether } \\
1997\end{array}$ & 0.0505 & 0.0166 & 0.0882 & 0.0161 & 0.0105 & -0.00745 \\
& $(0.0407)$ & $(0.0387)$ & $(0.0556)$ & $(0.0519)$ & $(0.0518)$ & $(0.0515)$
\end{tabular}




\begin{tabular}{|c|c|c|c|c|c|c|}
\hline Age & $\begin{array}{l}0.00837 \\
(0.0100)\end{array}$ & $\begin{array}{l}0.00801 \\
(0.0105)\end{array}$ & $\begin{array}{l}-0.00124 \\
(0.0132)\end{array}$ & $\begin{array}{l}-0.000399 \\
(0.0139)\end{array}$ & $\begin{array}{l}0.0184 \\
(0.0164)\end{array}$ & $\begin{array}{l}0.0208 \\
(0.0155)\end{array}$ \\
\hline \multicolumn{7}{|l|}{ Interactions } \\
\hline \multirow[t]{2}{*}{ Treated*Age } & 0.00903 & 0.0104 & 0.0157 & 0.0186 & 0.00245 & 0.00304 \\
\hline & $(0.0138)$ & $(0.0146)$ & $(0.0189)$ & $(0.0204)$ & $(0.0203)$ & $(0.0198)$ \\
\hline \multirow[t]{2}{*}{ Treated*Sibling 0-5 } & -0.00417 & -0.0133 & 0.00498 & -0.00878 & -0.0129 & -0.0180 \\
\hline & $(0.0238)$ & $(0.0242)$ & $(0.0284)$ & $(0.0289)$ & $(0.0302)$ & $(0.0321)$ \\
\hline \multirow[t]{2}{*}{ Treated*Sibling 6-13 } & $-0.0224^{*}$ & & $-0.0508 * * *$ & & 0.00620 & 0.0124 \\
\hline & $(0.0121)$ & & $(0.0172)$ & & $(0.0154)$ & $(0.0164)$ \\
\hline \multirow[t]{2}{*}{$\begin{array}{l}\text { Treated*Sibling 14- } \\
15\end{array}$} & 0.0125 & -0.00921 & 0.0393 & -0.00750 & -0.0126 & -0.0139 \\
\hline & $(0.0321)$ & $(0.0319)$ & $(0.0397)$ & $(0.0427)$ & $(0.0453)$ & $(0.0464)$ \\
\hline \multicolumn{7}{|l|}{ Number of siblings } \\
\hline \multirow[t]{2}{*}{ Aged 0 - 5} & -0.0153 & -0.0259 & -0.0299 & $-0.0467 * *$ & -0.000214 & -0.0278 \\
\hline & $(0.0193)$ & $(0.0172)$ & $(0.0232)$ & $(0.0224)$ & $(0.0246)$ & $(0.0244)$ \\
\hline \multirow[t]{2}{*}{ Aged $6-13$} & $0.0222 *$ & & 0.0295 & $-0.0275^{* *}$ & 0.0148 & $-0.0274 *$ \\
\hline & $(0.0130)$ & & $(0.0184)$ & $(0.0136)$ & $(0.0147)$ & $(0.0142)$ \\
\hline \multirow[t]{2}{*}{ Aged $14-15$} & 0.00345 & 0.00742 & -0.0260 & -0.0127 & 0.0308 & 0.0124 \\
\hline & $(0.0310)$ & $(0.0292)$ & $(0.0389)$ & $(0.0407)$ & $(0.0370)$ & $(0.0364)$ \\
\hline \multicolumn{7}{|c|}{ Province: Compared with Guerrero } \\
\hline \multirow[t]{2}{*}{ Hidalgo } & 0.0842 & -0.0248 & $0.119^{* *}$ & & 0.0479 & -0.0395 \\
\hline & $(0.0549)$ & $(0.0390)$ & $(0.0580)$ & & $(0.0642)$ & $(0.0463)$ \\
\hline \multirow[t]{2}{*}{ Michoacán } & $0.148 * * *$ & & $0.150^{* *}$ & & $0.148 * *$ & \\
\hline & $(0.0567)$ & & $(0.0680)$ & & $(0.0635)$ & \\
\hline \multirow[t]{2}{*}{ Puebla } & 0.0301 & $-0.0684 *$ & 0.0506 & -0.0674 & 0.0149 & \\
\hline & $(0.0583)$ & $(0.0383)$ & $(0.0605)$ & $(0.0460)$ & $(0.0677)$ & \\
\hline \multirow[t]{2}{*}{ Querétaro } & $0.202 * * *$ & & $0.239 * * *$ & & $0.166^{* *}$ & \\
\hline & $(0.0666)$ & & $(0.0743)$ & & $(0.0754)$ & \\
\hline \multirow[t]{2}{*}{ San Luis Potosí } & $0.100^{*}$ & & 0.0806 & -0.0604 & $0.115^{*}$ & \\
\hline & $(0.0528)$ & & $(0.0614)$ & $(0.0436)$ & $(0.0595)$ & \\
\hline \multirow[t]{2}{*}{ Veracruz } & $0.164 * * *$ & & $0.159 * * *$ & & $0.168 * * *$ & \\
\hline & $(0.0503)$ & & $(0.0535)$ & & $(0.0580)$ & \\
\hline \multirow[t]{2}{*}{ Household Size } & 0.00870 & $-0.0248 * * *$ & 0.0108 & $-0.0151^{*}$ & 0.00615 & -0.0112 \\
\hline & $(0.00934)$ & $(0.00503)$ & $(0.0126)$ & $(0.00895)$ & (0.0109) & $(0.00922)$ \\
\hline \multirow[t]{2}{*}{ Share of Children } & $1.321 * * *$ & & $1.341 * * *$ & & $1.310 * * *$ & \\
\hline & $(0.331)$ & & $(0.436)$ & & $(0.459)$ & \\
\hline \multirow[t]{2}{*}{ Whether Owns TV } & $-0.324 * * *$ & & $-0.325 * * *$ & & $-0.328 * * *$ & \\
\hline & $(0.0262)$ & & $(0.0325)$ & & $(0.0292)$ & \\
\hline \multirow[t]{2}{*}{ Whether Owns Car } & $-0.105^{* * *}$ & & $-0.0833^{* *}$ & & $-0.125 * * *$ & \\
\hline & $(0.0238)$ & & $(0.0328)$ & & $(0.0341)$ & \\
\hline \multirow[t]{2}{*}{$\begin{array}{l}\text { Whether } \\
\text { House }\end{array}$} & $-0.447 * * *$ & & $-0.504 * * *$ & & $-0.424 * * *$ & \\
\hline & $(0.0670)$ & & $(0.111)$ & & $(0.0888)$ & \\
\hline \multirow[t]{2}{*}{$\begin{array}{l}\text { Whether with } \\
\text { disabled member }\end{array}$} & -0.0562 & -0.0492 & -0.0582 & -0.0580 & -0.0429 & -0.0601 \\
\hline & $(0.0352)$ & $(0.0426)$ & $(0.0445)$ & $(0.0536)$ & $(0.0576)$ & $(0.0648)$ \\
\hline \multirow[t]{2}{*}{ Poverty Rate in 1997} & $0.000425 * * *$ & & $0.000398 * *$ & & $0.000440 * *$ & \\
\hline & $(0.000146)$ & & $(0.000164)$ & & $(0.000185)$ & \\
\hline $\mathrm{N}$ & 4500 & 4500 & 2226 & 2226 & 2274 & 2274 \\
\hline
\end{tabular}

Notes: Standard errors are clustered at the village level. Robust standard errors in parentheses: $* \mathrm{p}<0.10 * * \mathrm{p}<0.05 * * * \mathrm{p}<0.01$. Source: Authors' elaboration based on ENCASEH and ENCEL data. 
Online Appendix Table 3.6: Unrestricted and Restricted Attrition Probit Model: All non-poor sample 13-18

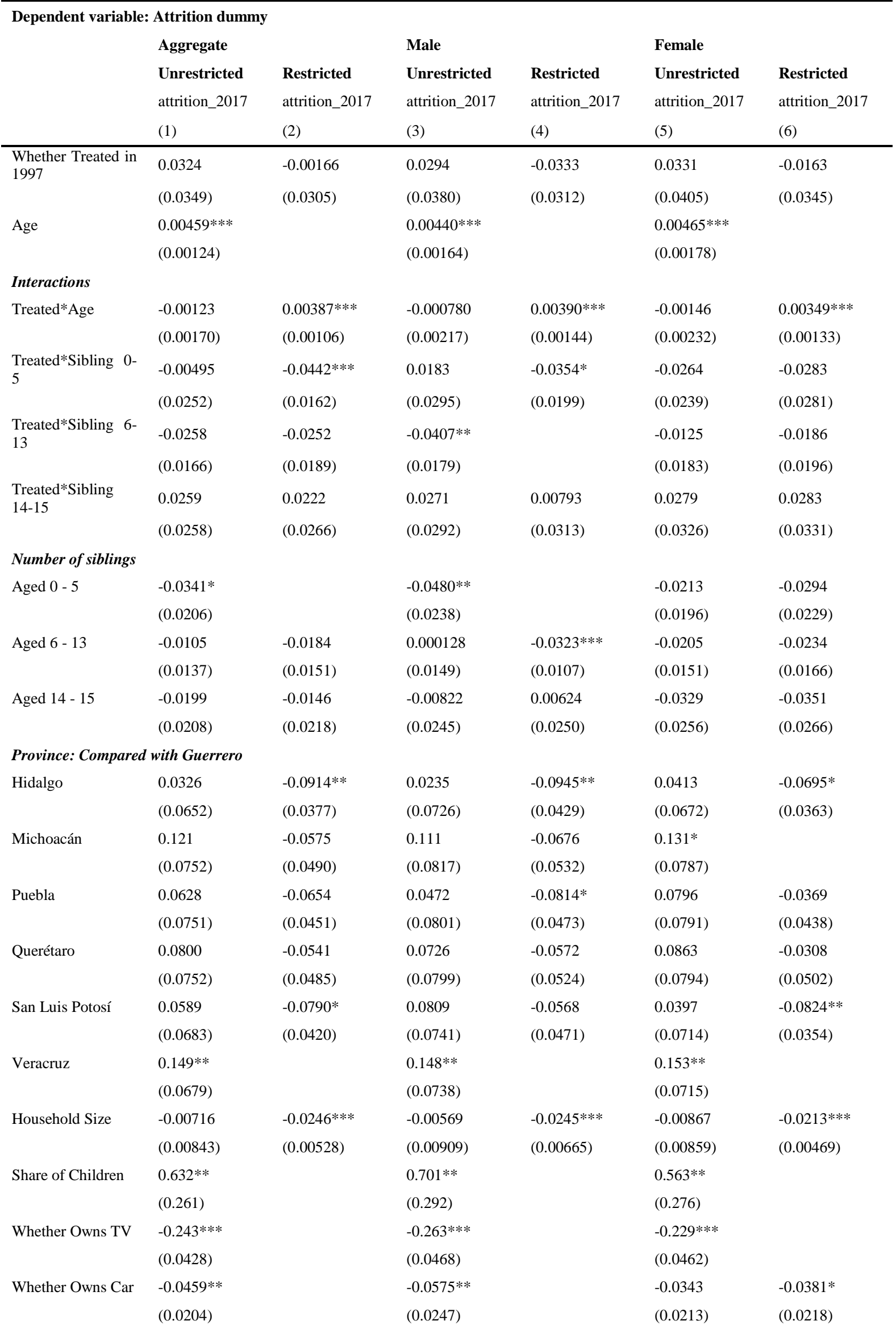




\begin{tabular}{|c|c|c|c|c|c|c|}
\hline \multirow[t]{2}{*}{$\begin{array}{l}\text { Whether } \\
\text { House }\end{array}$} & \multicolumn{2}{|l|}{$-0.425 * * *$} & \multicolumn{2}{|l|}{$-0.466 * * *$} & \multicolumn{2}{|l|}{$-0.396 * * *$} \\
\hline & $(0.0902)$ & & $(0.100)$ & & $(0.0998)$ & \\
\hline \multirow[t]{2}{*}{$\begin{array}{l}\text { Whether with } \\
\text { disabled member }\end{array}$} & -0.00234 & 0.00467 & 0.0200 & 0.0204 & -0.0205 & -0.0145 \\
\hline & $(0.0315)$ & $(0.0332)$ & $(0.0377)$ & $(0.0398)$ & $(0.0390)$ & $(0.0398)$ \\
\hline \multirow[t]{2}{*}{$\begin{array}{l}\text { Poverty Rate } \\
1997\end{array}$} & $0.000298 * * *$ & & $0.000281 * * *$ & & $0.000314 * * *$ & \\
\hline & (0.0000909) & & $(0.000102)$ & & $(0.000103)$ & \\
\hline $\mathrm{N}$ & 12956 & 12956 & 6293 & 6293 & 6663 & 6663 \\
\hline
\end{tabular}

Notes: Standard errors are clustered at the village level. Robust standard errors in parentheses: * $\mathrm{p}<0.10 * * \mathrm{p}<0.05 * * * \mathrm{p}<0.01$. Source: Authors' elaboration based on ENCASEH and ENCEL data.

Online Appendix Figure 1: Age breakdown in 1997

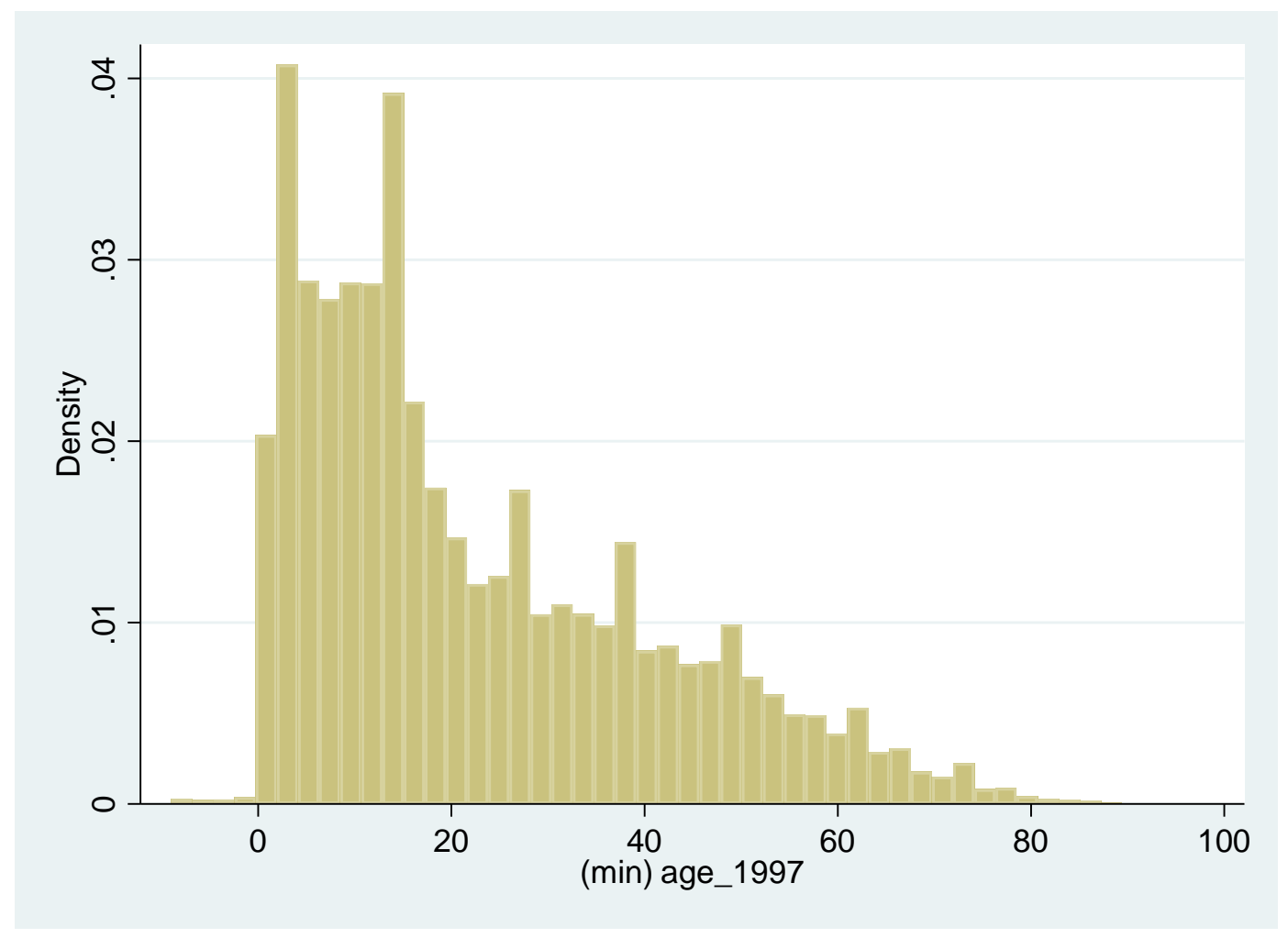

Source: Authors' elaboration based on ENCASEH and ENCEL data 